\title{
The Salmas (Iran) earthquake of May 6th, 1930
}

\author{
J. S. TChalenko $(*)-$ M. Berberian (**)
}

Received on March 20th, 1974

\begin{abstract}
Summary. - Field investigations and bibliographical research into the little-known but important Salmas earthquake in Northwest Azarbaijan (Iran) provided the following results. The morning before the earthquake, a foreshock $\left(M_{b}-5.4\right)$ centered, as the main shock, in the Salmas Plain, killed about 25 people and incited a great part of the population to spend the following night out of doors. The main shock $\left(M I_{b}=7.3\right)$ occurred the following night, on 6 May 1930 at $22 \mathrm{~h} 34 \mathrm{~m} 27 \mathrm{~s}$ G.IT and destroyed about 60 villages and 40 churches, killing about 2514 people, both in the Salmas Plain and in the surrounding mountains. Its macroseismic epicentre was at approximately $38.15 \mathrm{~N} 44.70 \mathrm{E}$. The main shock was associated with 2 surface faults, with a maximum horizontal displacement of $4 \mathrm{~m}$ and vertical displacement of over $5 \mathrm{~m}$; the combined action of these faults was a relative lowering, and a displacement to the east, of the Salmas Plain. Two days later, the strongest aftershock destrojed one village at the northern edge of the Salmas Plain.
\end{abstract}

Riassunto. - Gli studi fatti e le ricerche bibliografiche hanno dato sul poco conosciuto ma importante terremoto di Salmas (Azarbaijan, nordoccidentale, Iran) le seguenti informazioni.

La mattina prima del terremoto, nella Piana di Salmas una scossa premonitoria $\left(M_{b}=5.4\right)$, ritenuta la principale, causò circa 25 morti costringendo una gran parte della popolazione a trascorrere la notte all'aperto. La notte seguente, 6 Maggio 1930 alle $22134 \mathrm{~m} 27$ s GMT, avvenne la scossa principale che distrusse, nella Piana di Salmas e nelle montagne circostanti, circa 60 villaggi e 40 chiese provocando la morte di circa 2514 persone. Il suo epicentro macrosismico fu approssimativamente a $38.15^{\circ} \mathrm{N}$ e $44.70^{\circ} \mathrm{E}$. don SIV7.

(*) Engineering Seismology Section, Imperial College of Science. Lon-

(**) Geological Survey of Iran, P.O. Box 1964. Tehran. 
La scossa principale si associò a rlue faglie superficiali, con uno spostamento massimo orizzontale di $+\mathrm{m}$ e verticale di oltre $5 \mathrm{~m}$; lazione combinata di queste due faglie provocò un abhassamento relativo ed uno spostamento verso Est della Piana di Salmas. Due giorni dopo, la replica più forte di. strusse un villaggio all'estremo nord della Piana di Salmas.

\section{INTRODUCTION}

The Salmas earthquake of 1930 is one of the 8 earthquakes of magnitude equal to, or greater than, 7, which occurred in Iran since 1900, and one of the few which was accompanied by surface faulting. It is also the only recent catastrophic earthquake located in the northwestern part of the country, a fact which makes it important in regional seismotectonic sturlies. Yet, to date, the rlocumentation on this event was practically reduced to entries in earthquake catalogues and to vague communiques in the international press. The field study and the new bibliographical material reported here has, it is believer. producel enough data to make certain aspects of this earthquake, such as casualty distribution and faulting, as well documented as in the case of more recent destructive earthquakes (e.g. Buyin Zahra 1962, Dasht-e Bayaz 1968). This improved knowledge of the event is, to a large extent, rue to several favourable circumstances which will become apparent in the course of this report.

The aim of this report is intentionally limited to a presentation of the observations that we collecter on the earthquake and its immerliate effects. No attempt is marle to interpret this information, either in terms of the seismicity (historical or morlern), or in terms of the regional tectonics, and this for the simple reason that very little is known, and even less is published, on either of these subjects. The geological mapping of the region, for example, has only just begun. The report is itself a summary of a more complete documentation in preparation $\left({ }^{2}\right)$.

The Salmas Plain, epicentral region of the earthquake, is located to the northwest of Lake Rezayeh, and has an area of about $300 \mathrm{~km}^{2}$ (Figs 1 and 3). It lies between the levels of about $1500 \mathrm{~m}(\mathrm{~N}, \mathrm{~W}$ and $\mathrm{S}$ borlers) and $1280 \mathrm{~m}$, the latter being the average level of the Lake which forms its eastern borler. The Plain is watererl by the Zola Chay which is the mainstay of its agricultural prosperity. The most important villages are concentrated in the southwest, and many, such 


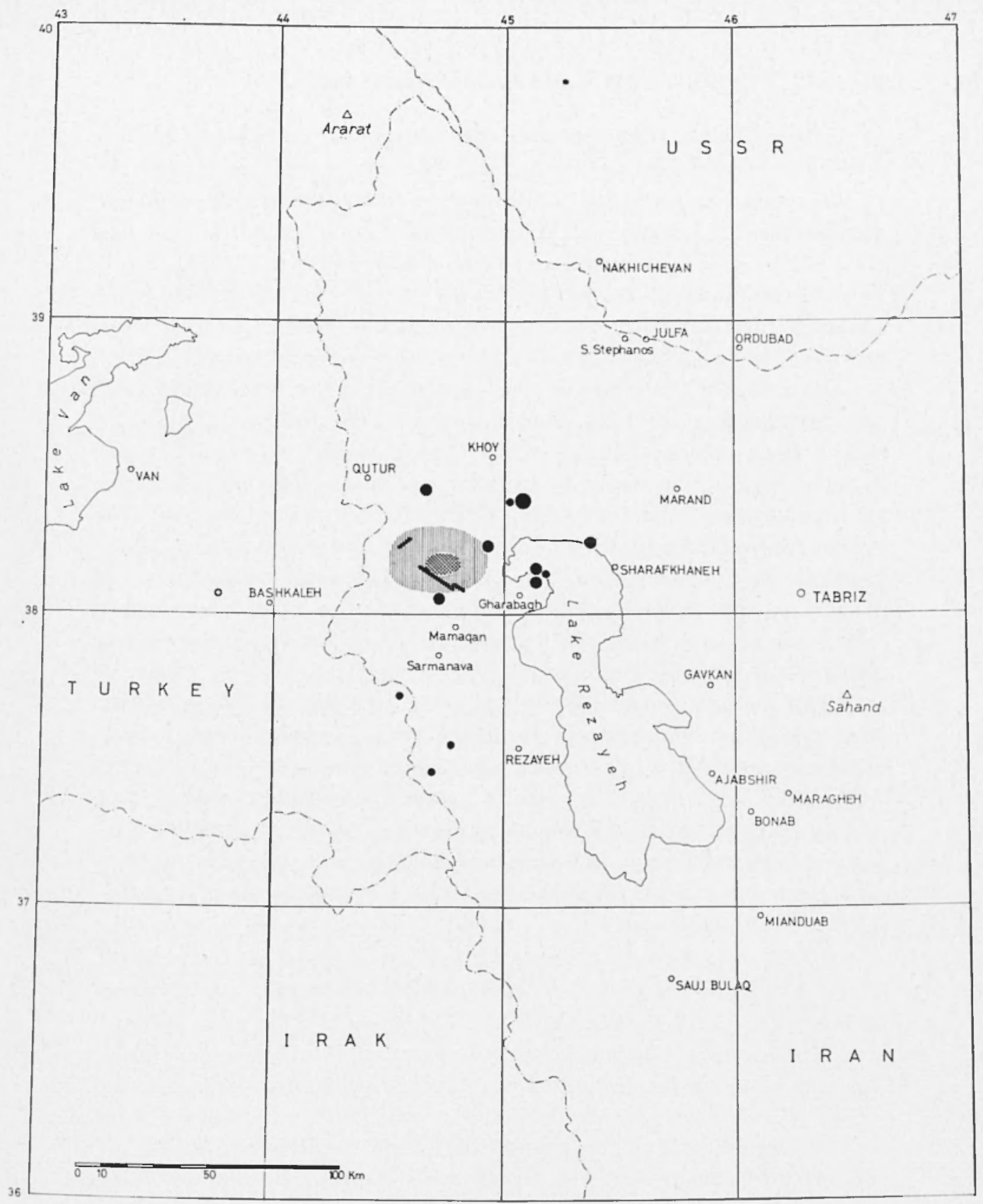

Fig. 1 - Epicentral. Regions, earthquake faults añ main aftershocks

Epicentral regions of 6 May 1930 foreshock and main shock are shaded respectively with cross-hatching and vertical hatching. Fault breacks are shown with thick black line. Instrumental epicentres of main aftershocks (see Table 3) are shown with dots, largest dot $M \geqslant 6$, intermediate $5 \leqslant M<6$, smallest $\mathrm{II}<5$. Iargest aftershock occurred southwest of Khoy on 8 Ilay 1930. Open dot west of Bashkaleh is an early shock on 16 April 1930. The instrumental epicentres of the foreshock and main shock are not shown because their accuracy is inferior to the macroseismic determination. Towns shown are those where the main shock was reported as felt, excep Leninakan and Tiflis which are located outside of this map. 
as Kohneh Shahr (replaced after the earthquake by Tazeh Shahr), were of considerable antiquity (14). The Plain was populated by Christians of the Nestorian and Chaldean sects from a very early age (S. Hovanes in Ghezelja is thought to have been built in 1007), and at the time of the earthquake, 15 of its villages were either exclusively or partly inhabited by them. The town however, Dilman (or Dilmaghan renamed Shahpur after the earthquake), and villages in the north and east, were mainly of Turkish and Kurdish population.

The mountains bordering the Salmas Plain are much more sparsely populater, mainly by Kurdish people. The highest summit, the Aravil Dagi, is located in the west on the Turkish frontier; it is a volcano which ferl the many Quaternary basalt flows forming the high plateaux between the Dowshivan Su and the Zola Chay (Fig. 3). The much lower Miocene hills in the north, and the metamorphic mountains in the south, separate the Salmas Plain respectively from the Khoy and the Rezayeh Plains. The mountain villages are small, isolated from each other and from the Plain, and live nearly entirely from wheat farming and cattle.

The method we used in this investigation was to visit each village, gradually defining the epicentral region, observing ground deformations and ruins of the earthquake which were often little changed since 1930. As many survivors as possible were interviewerl in each village in their native dialect, i.e. Armenian, Assyrian, Turkish, Kurdish and Persian. New bibliographical material in the form of newspaper reports and private correspondence was used to check and supplement the field results.

\section{Foreshock}

\section{General.}

A moderately strong foreshock, of estimated magnitude $M_{b}=5.4\left(^{10}\right)$, occurred on 6 May 1930 at 07 h03m26s GMT, i.e. about $151 / 2$ hours before the main shock. It caused destruction and some casualties in a small region centered at about $38.15^{\circ} \mathrm{N} 44.75^{\circ} \mathrm{E}$ corresponding approximately to the future macroseismic epicentre of the main shock. The foreshock was perceptible over all of Northwestern Azarbaijan and Southeastern Turkey, and was clearly felt by most of the inhabitants in the three nearest towns, Tabriz, Rezayeh and Khoy, 
as well as in Bonar and Maragheh. A large part of the population in the epicentral region spent the night following the foreshock out of doors, and was thus saved when the main shock occurred.

\section{Casualties and destruction.}

The effect of the foreshock on the villages, mainly of adobe construction, is summarized in Fig. 2. As the event occurred at about 10 a.m. local time, many people were out, or could escape quickly from their houses, and as a result the number of casualties remained relatively low.

Four localities, Haftavan, Dilman, Kuche Mashk and Kalashan, were severely damaged and had casualties. In Haftavan, some houses collapsed completely, and one woman and one child were killed by a falling wall. The roof of $\mathrm{S}$. Thadeus, a large stone-masonry and kiln-brick church west of Haftavan, collapsed. In Dilman, many houses were badly damaged, and between 15 and 20 people were killed (Tabriz 8 May, Haratch 22 and 23 May). In Kuche Mashk and Kalashan nearly all houses were damaged, and one person was killed in each village. This region of maximum destruction is centered in the region of $\mathrm{S}$. Thadeus which may be taken as the approximate macroseismic epicentre of the foreshock.

In the surrounding villages of Kohneh Shahr, Patehvir, Sarnaq and Payajuk, a few buildings collapsed partially, and most others were fissured. In Kohneh Shahr damage was said to have been more severe (Tabriz 8 May), but the subsequent departure from the village of many of its original inhabitants made it impossible to verify this information. In other villages such as Malham, Uleh, Khosrova, Drishik, Moghanjik, Sadaghian and Hamzekandi, most houses were fissured. Further away from the epicentral region, in Habashi, Akhtekhaneh, Yavshanli, Khantakhti, Tamar, Ayan and Senji, only a few isolated walls were fissured.

In all the villages mentioned above, and in a few other near-by ones, the foreshock was felt strongly enough for most of the inhabitants (with the exception of those of Malham) to decide to spend the following night out of doors (see Table 1). Outside this region however, and especially in the mountains to the north and west, the shock was felt too lightly to worry the population which consequently spent the night indoors and suffered a large number of casualties when the main shock occurred at about 01.30 a.m. local time. The villages 
Table 1 - Damage and casuatries caused by tIE MaI SHOCK All information was obtained by ficld survey in 1973 , except ST (Samson Tateossian in Haratch $31 . \mathrm{Ma}$ 1930) and $\mathrm{AZ}$ (Abel Zayia in Zayia, 1930a,b).

\begin{tabular}{|c|c|c|c|c|}
\hline Village & 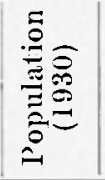 & Earthquake Damage & 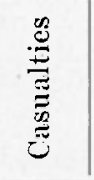 & Remarks \\
\hline Akhian & 0 & & & $\begin{array}{l}\text { not inhabited in } \\
1930 \text { ? }\end{array}$ \\
\hline Akhtekhanch & & $\begin{array}{l}\text { village destroyed; } \\
\text { chureh standing }\end{array}$ & 4 & most slept out \\
\hline Alibolagh & & destroyed & & \\
\hline Aqbarzeh & & about $50 \%$ destroyed & 1 & \\
\hline Aqziarat & 110 & about $10 \%$ collapsed & 0 & most slept out \\
\hline Ashnak & 120 & destroyed & 27 & most slept in \\
\hline Aslanik & 110 & completely destroyed & 21 & most slept in \\
\hline Ayan & 270 & about $50 \%$ collapsed & 12 & \\
\hline Bajergeh & 90 & not damaged & 0 & \\
\hline Balgha\%an & 50 & about $10 \%$ collapsed & 0 & \\
\hline Bardian & & slightly damaged & 0 & most slept out \\
\hline Borushigalan & 40 & destroyed & 17 & most slept in \\
\hline Bostakabad & & lightly damaged & 0 & \\
\hline Chahar-Sutun & 200 & about $6 \%$ collapsed & 0 & \\
\hline Chaliriq & 120 & about $75 \%$ collapsed & 4 & most slept out \\
\hline Chichak & 270 & about $50 \%$ collapsed & 15 & most slept out \\
\hline Derik & 180 & $\begin{array}{l}\text { village destroyed; } \\
\text { chureh mostly col- } \\
\text { lapsed }\end{array}$ & 25 & most slept out \\
\hline Dikeh & & not damaged & 0 & \\
\hline Dilman & 18000 & completely destroyed & 1100 & $\begin{array}{l}\text { more slept out } \\
\text { than in }\end{array}$ \\
\hline Dishivan & 0 & & & $\begin{array}{l}\text { not inluabited in } \\
1930\end{array}$ \\
\hline Djamlava & & slightly damaged & 0 & $(A . Z)$ \\
\hline Drishik & 390 & completely destroyed & 2 & most slept out \\
\hline Galvan & 0 & & & $\begin{array}{l}\text { not inhabited in } \\
1930\end{array}$ \\
\hline Gavilan & & slightly damaged & 0 & (A.Z.) \\
\hline Gilabrabad & 140 & completely destroyed & 13 & \\
\hline Ghalasar & 79 & $\begin{array}{l}\text { village destroyed; } \\
\text { church partly col- } \\
\text { lapsed }\end{array}$ & 2 & most slept out \\
\hline Gharabagh & 2400 & $\begin{array}{l}\text { about } 30 \% \text { collapsed; } \\
\text { church undamaged }\end{array}$ & 3 & most slept out \\
\hline Gharaqeshlagh & 1650 & slight damage & 0 & most slept out \\
\hline Ghezelja & 420 & $\begin{array}{l}\text { village destroyed; } \\
\text { church standing }\end{array}$ & 3 & many slept out \\
\hline $\begin{array}{l}\text { Ghezelkandi } \\
\text { Goniel }\end{array}$ & 40 & $\begin{array}{l}\text { about } 50 \% \text { destroyed } \\
\text { not damaged }\end{array}$ & $\begin{array}{l}1 \\
0\end{array}$ & \\
\hline
\end{tabular}




\begin{tabular}{|c|c|c|c|c|}
\hline Village & 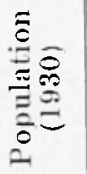 & Eartlquake Damage & 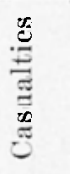 & Remarks \\
\hline Guba & 120 & about $25 \%$ collapsed & 0 & most slept out \\
\hline Guladar & 30 & completely destroyed & 6 & most slpet in \\
\hline Gulan & $90 ?$ & a few houses collapsed & 0 & \\
\hline $\begin{array}{l}\text { Gulizan } \\
\text { Guzik }\end{array}$ & & $\begin{array}{l}\text { destroyed } \\
\text { destroyed }\end{array}$ & 3 & \\
\hline IIabashi & 690 & destroyed & 2 & most slept out \\
\hline II ablaran & 90 & destroyerl & 35 & most slept in \\
\hline IIaftavan & 540 & $\begin{array}{l}\text { destroyed, including } 3 \\
\text { of } 4 \text { churches }\end{array}$ & 4 & all slept out (ST) \\
\hline Inaji Jafan & 90 & not dlamaged & 0 & \\
\hline IIamzelı Kandi & 330 & completely destroyed & 16 & most slept out \\
\hline IIanik & & damaged & $2 ?$ & \\
\hline Iagviran & & destroyed & & \\
\hline II asbashi & 0 & & & $\begin{array}{l}\text { not inluabited in } \\
1930\end{array}$ \\
\hline IIosseinabad & & not dlamaged & 0 & \\
\hline IIowrlar & 360 & mostly destroyed & $0 ?$ & $?$ \\
\hline Issy Su & & light damage & 0 & \\
\hline Kahriz & 50 & destroyed & 1 & some slept in \\
\hline Kaleshan & 180 & completely destroyed & 19 & many slept out \\
\hline Kanyan & 600 & very little damage & 0 & most slept in \\
\hline $\begin{array}{l}\text { Kashkavich } \\
\text { Khanagah }\end{array}$ & 120 & $\begin{array}{l}\text { about } 15 \% \text { collapsed } \\
\text { ? }\end{array}$ & 2 & most slept in \\
\hline Khantakhti & 180 & ilestroyed & 0 & most slept out \\
\hline Khorkhora & 40 & destroyed & 2 & \\
\hline Khosrowa & 280 & $\begin{array}{l}\text { destroyed, including } 7 \\
\text { churches }\end{array}$ & 34 & $\begin{array}{l}\text { most slept out } \\
\text { (ST, A\%) }\end{array}$ \\
\hline Kohneh Shahr & 2290 & $\begin{array}{l}\text { destroyer, including } 5 \\
\text { churches }\end{array}$ & 370 & most slept out \\
\hline Kuche Mashk & 210 & completely destroyed & 0 & most slept out \\
\hline Kurdran & 40 & destroyed & 3 & \\
\hline Kuzerash & & destroyed & 35 & most slept in \\
\hline $\begin{array}{l}\text { Jashliaran } \\
\text { Mafi Kandi }\end{array}$ & 120 & $\begin{array}{l}\text { destroyed } \\
\text { no information }\end{array}$ & 0 & most slept out \\
\hline Mallam & 327 & $\begin{array}{l}\text { completely destroyed, } \\
\text { including } 3 \text { churches }\end{array}$ & 48 & most slept in (ST) \\
\hline $\begin{array}{l}\text { Mamaqan } \\
\text { Masdayan }\end{array}$ & 600 & $\begin{array}{l}\text { destroyed } \\
\text { not destroyed }\end{array}$ & 85 & \\
\hline Minas & & destroyed & 0 & most slept out \\
\hline Mlingrol & 120 & $5 \%$ collapsed & 2 & most slept in \\
\hline Moghanjik & 1800 & completely destroyed & 75 & many slept out \\
\hline Nazirabad & 130 & completely destroyed & 30 & $\begin{array}{l}\text { about } 60 \% \text { slept } \\
\text { out }\end{array}$ \\
\hline
\end{tabular}


(continued)

\begin{tabular}{|c|c|c|c|c|}
\hline Village & 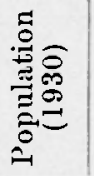 & Earthquake Damage & 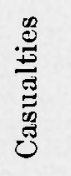 & Remarks \\
\hline Patehvir & 113 & $\begin{array}{l}\text { destroyed, including } \\
\text { churches }\end{array}$ & 11 & $\begin{array}{l}\operatorname{many} \text { slept out } \\
(\mathrm{ST}, \mathrm{AZ})\end{array}$ \\
\hline Payajuk & 130 & $\begin{array}{l}\text { destroyed, including } \\
\text { church }\end{array}$ & 3 & $\underset{\text { (ST) }}{\text { most slept out }}$ \\
\hline Sadaghian & 1050 & completely destroyed & 60 & $\begin{array}{l}\text { about } 50 \% \text { slept } \\
\text { out }\end{array}$ \\
\hline Sailab & 600 & partly destroyed & 1 & most slept out \\
\hline Saramerik & 960 & completely destroyed & 82 & most slept in \\
\hline Sarmanava & 170 & partly destroyed & 8 & most slept in \\
\hline Sarnaq & 180 & $\begin{array}{l}\text { village destroyed; } \\
\text { church mostly col- } \\
\text { lapsed }\end{array}$ & 18 & most slept out \\
\hline Savran & 626 & $\begin{array}{l}\text { completel destroyed; } \\
\text { including } 2 \text { churches }\end{array}$ & 151 & $\underset{\text { (ST) }}{\operatorname{most}}$ slept out \\
\hline Senji & 120 & completely destroyed & 21 & most slept out \\
\hline Shekar Yazi & 960 & little damaged & 0 & most slept in \\
\hline Sheydan & 90 & about $80 \%$ destroyed & 1 & most slept in \\
\hline Sheytanava & 0 & & & $\begin{array}{l}\text { not inhabited in } \\
1930\end{array}$ \\
\hline Shiveh & & not damaged & 0 & \\
\hline Shiveh Darreh & & not damaged & 0 & \\
\hline Shurgel & 330 & about $30 \%$ collapsed & 0 & most slept out \\
\hline Shurik & & moderately damaged & 0 & \\
\hline Siavan & & lightly damaged & 0 & \\
\hline Sidan & & not damaged & 0 & \\
\hline Soltan Ahmed & 1200 & $\begin{array}{l}\text { about } 20 \% \text { of the hou- } \\
\text { ses collapsed }\end{array}$ & 0 & most slept out \\
\hline Sowfiabad & 60 & destroyed & 11 & \\
\hline Sutunrash & 0 & & & $\begin{array}{l}\text { not inhabited in } \\
1930\end{array}$ \\
\hline Tamar & 660 & completely destroyed & 52 & most slept out \\
\hline Uleh & 1200 & completely destroyed & 12 & most slept out \\
\hline Urban & $390 ?$ & moderately damaged & 0 & \\
\hline Vardan & 480 & destroyed & 25 & most slept in \\
\hline Yavshanlu & 420 & $\begin{array}{l}\text { moderately damaged, } \\
\text { many houses stand- } \\
\text { ing }\end{array}$ & 0 & most slept out \\
\hline Yengijelı & 110 & completely destroyed & 18 & \\
\hline Zavichjuk & 240 & $\begin{array}{l}\text { destroyed; } 1 \text { church } \\
\text { undamaged }\end{array}$ & 10 & most slept out \\
\hline Zindasht & 70 & lightly damaged & $\begin{array}{l}0 \\
3\end{array}$ & \\
\hline & 10 & & 3 & $\begin{array}{l}\text { about } 50 \% \text { slept } \\
\text { out }\end{array}$ \\
\hline
\end{tabular}




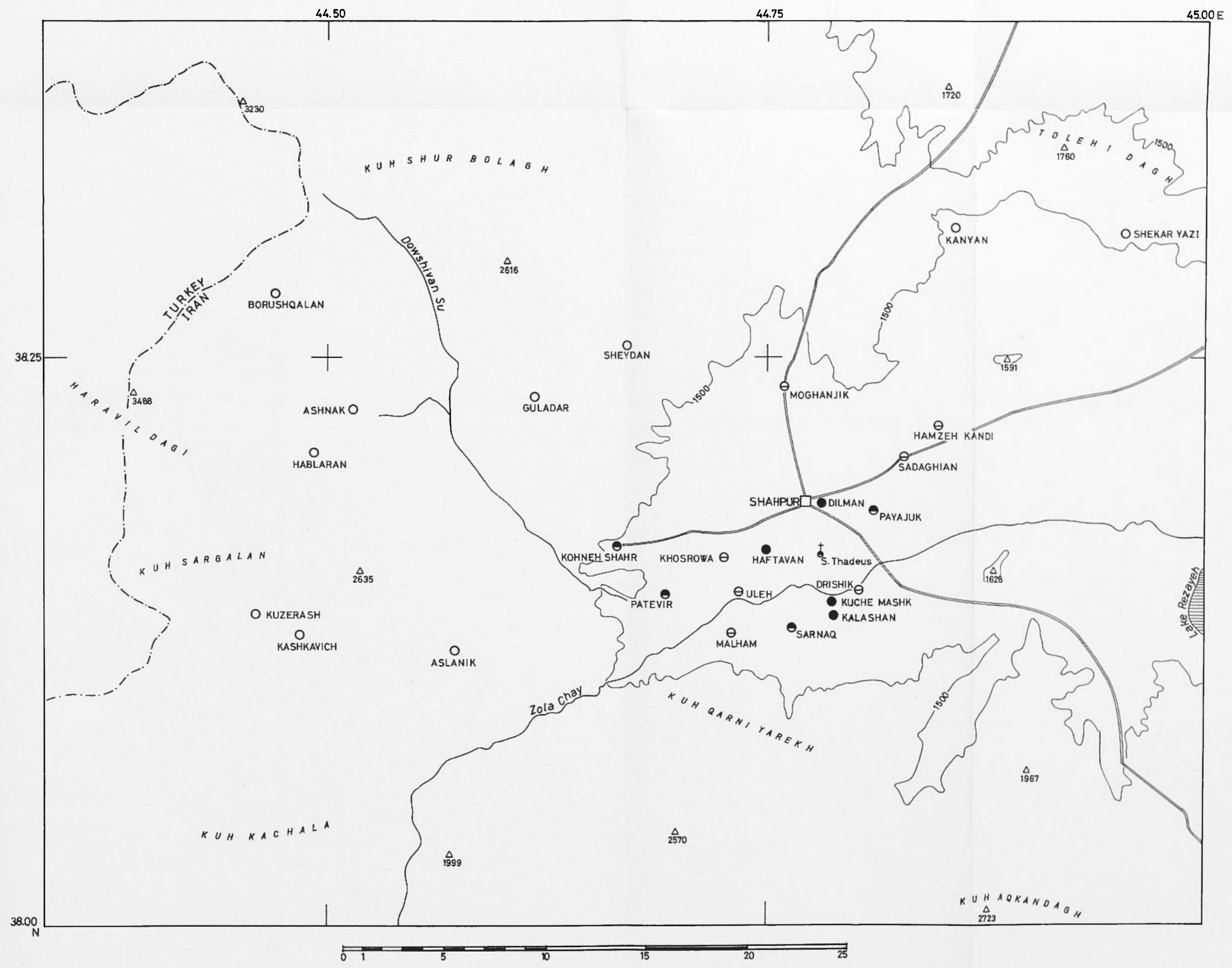

Fig. 2 - FORESHOCK OF 6 MAY 1930

- severe destruction and fatalities; $\theta$ some buildings collapsed; $\theta$ most

buildings fissured; $O$ foreshock not heeded or not felt. The approximate macroseismic epicentre was S. Thadeus church which was partly destroyed. Heights in meters. 


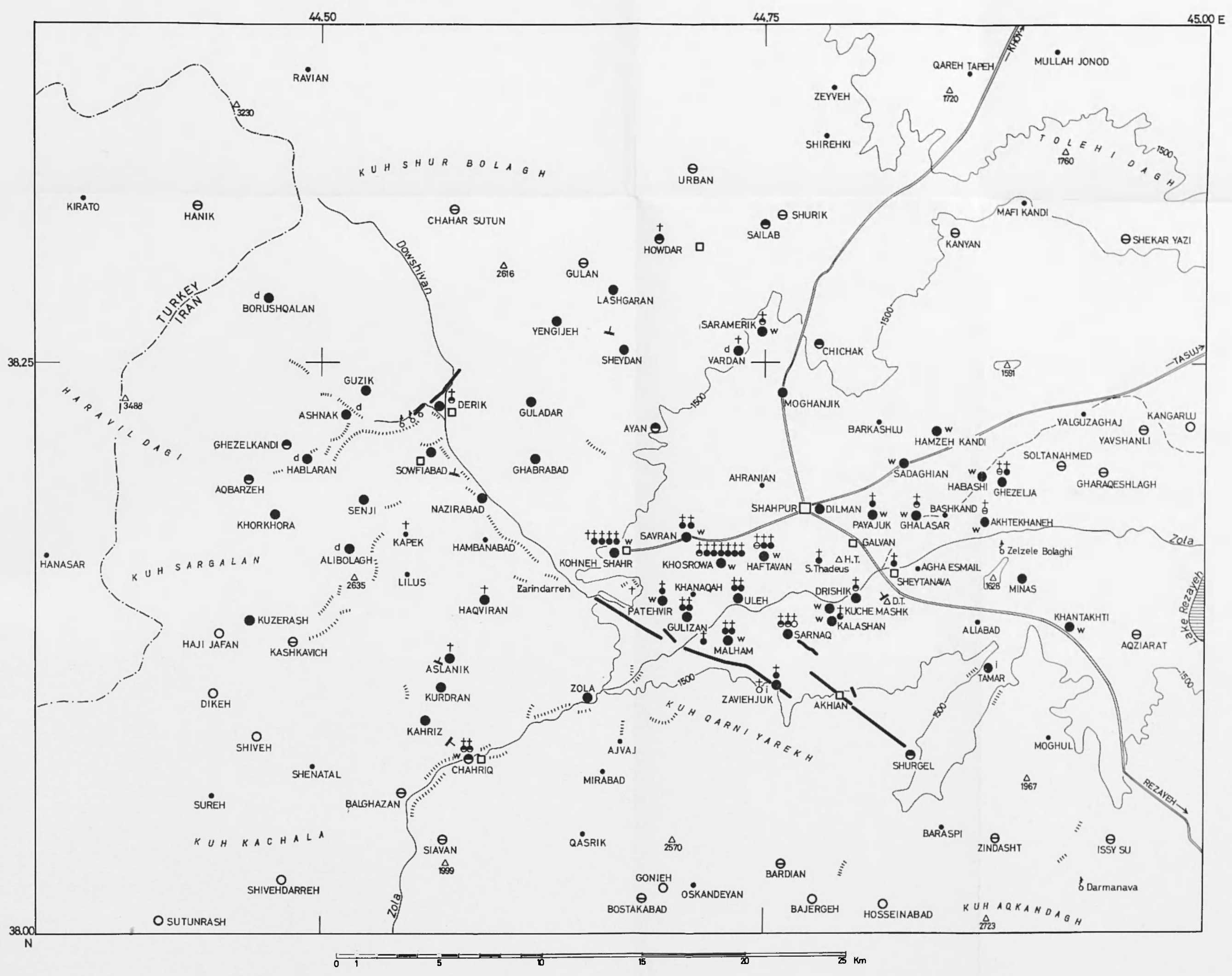

Fig. 3 - MalN SHOCK of 6 MaY 1930

Village destruction estimated at:

- $75-100 \%$ - $25-75 \% \quad \ominus 0-25 \% \quad \bigcirc 0 \%$ - no information available

Damage to churches:

t destroyed t partly destroyed t fissured tundamaged

+ church destroyed before 1930

- fault-break tchanged thermal spring $\mathrm{m} \cdot \mathrm{m}$, rockfall

landslide or rockslide $\mathrm{w}=$ waterlogging $\mathrm{d}=$ springs decreased $\mathrm{i}=$ springs increased

HT Haftavan Tepe, DT Drishik Tepe. New (post-1930) villages shown as squares. Heights in meters. 
where the foreshock was not felt or heeded were Shekar Yazi, Kanyan, Sheydan, Guladar, Ashnak, Kuzerash, Kashkavich and Aslanik. In the extreme northwest, the shock was apparently not felt by anyone in Hablaran and Borushqalan.

\section{MAIN SIIOCK}

\section{General.}

The main shock occurred during the night which followed the foreshock, on 6 May 1930 at $22 \mathrm{~h} 34 \mathrm{~m} 27 \mathrm{~s}$ GMT (or 7 May 1930 at $01 \mathrm{~h} 34 \mathrm{~m} 27 \mathrm{~s}$ local time). Its magnitude was given as $7.2\left(^{8}\right)$, or $7.4\left(^{1}\right)$. About 60 villages located in the Salmas Plain and in the surrounding mountains were destroyed, and about 40 churches were destroyed or damaged (Tables 1 and 2). Casualties, which occurred nearly exclusively amongst the section of the population which had not heeded the foreshock, amounted to about 2,514 killed (Table 1). Two surface faults were formed with the earthquake: the first, oriented NWSE, and located at the southern edge of the Salmas Plain, was about $20 \mathrm{~km}$ long and displayed a maximum right-lateral movement of $4 \mathrm{~m}$ and a maximum vertical throw ( $\mathrm{NE}$ down) of about $5 \mathrm{~m}$; the second, oriented NE-SW, and located in the western mountains, was over $3 \mathrm{~km}$ long, left-lateral, and had a vertical throw (NW down) of about $1 \mathrm{~m}$. A recent recalculation located the instrumental epicentre at $38.22 \mathrm{~N} 44.66 \mathrm{E}\left({ }^{16}\right)$, which is in good agreement with the centre of the region of maximum destruction (macroseismic epicentre) found in this study to be approximately $38.15 \mathrm{~N}+4.70 \mathrm{E}$. Hence foreshock and main shock had, to a first approximation, nearly identical epicentres.

Outside the epicentral region, Khoy, Qutur and Sharafkhaneh were slightly damaged. In Tabriz, the shock caused panic, and part of the population fled the town. In the north, it was felt with intensities between 4 and 6 bals (13) in Julfa, Nakhichevan, Ordubad, and was even reported as felt in Leninakan and Tiflis. Near Julfa (North Iran), the eastern wall of $\mathrm{S}$. Stephanos developed a vertical central crack (Fig. 4), probably as a result of unequal foundation settlement. In the west the shock was felt in Bashkaleh and as far as Van in Turkey, and in the south as far as Sanj Bulaq. 


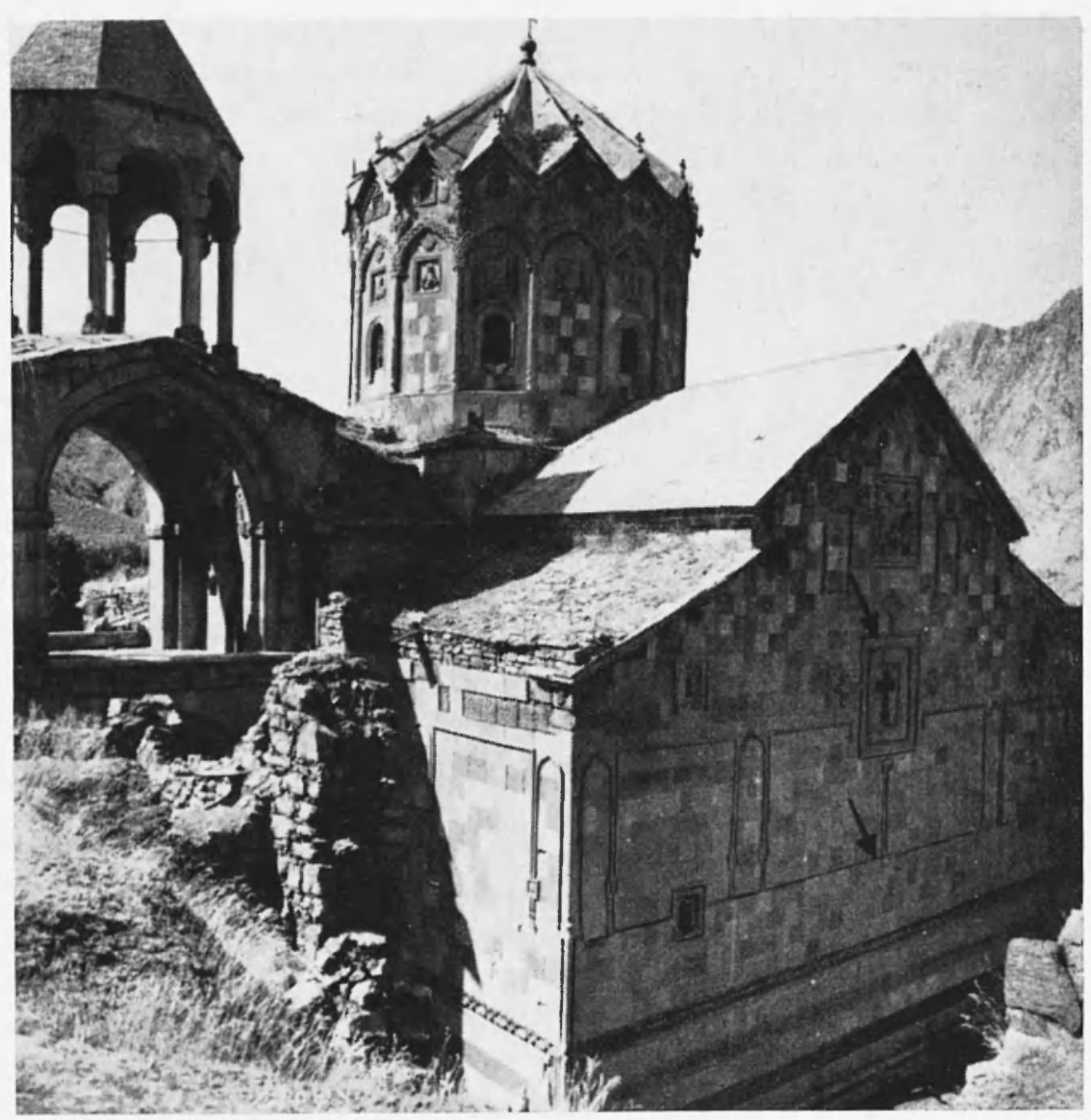

Fig. 4 - S. Stepilanos near Julfa

Located over $100 \mathrm{~km}$ to the northeast of the epicentral region, the eastern wall of this 16 th $e$ echurch developed a vertical fissure (shown by arrow) from apex to ground level.

\section{byewitness account.}

The main shock was witnessed by $\Lambda$ bel Zayia, a Persian Lazarist of the French Mission in Rezayeh, who, at the news of the foreshock, left Rezayeh to investigate the damage in Salmas. The account given refers to the effects as felt in the southeastern part of the epicentral region, at a point on the Rezayeh-Dilman road just north of the present-day village of Aliabad, and sonth of the isolated mountain (marked 
1628 in Figs 2 and 3 ) which contains a well-known Sassanian basrelief. The extracts which follow are translated from the French by the present authors.

" $\Lambda$ t half-past one in the morning we were just in front of the Suratis mountain (bas-relief), one of the car's hearlights broke-down, the driver got out to repair it. Suldenly I felt the car shake and thrown upwards; it was projected from south to north and displaced by $50 \mathrm{~cm}\left({ }^{*}\right)$. The driver was thrown down onto the ground" $\left({ }^{21}\right)$. "The driver was lying on the road. I thought that the car was out of control and instinctively reached for the brake and ignition key, when I heard a terrible noise: it was the rocks rolling lown from the mountain. I quickly got out of the ear, but what difficulty to remain standing. Not being able to alvance or go back, we waited for two hours; I looked upwards to see the apparition of the sign of the Son of Man. During this time there were seven formidable shocks and more than one thousand weaker ones" (22).

\section{Casualties and destruction.}

Over 60 villages of the epicentral region were studied in $1973 \mathrm{in}$ the field, and in most of them survivors of the earthquake could be found and interviewed. A limited amount of information was also compiled from existing contemporary accounts and newspaper reports. The results of this investigation are summarized in Fig. 3 and Tables 1 and 2, and are described in more detail below.

Two peculiarities distinguish this earthquake from most other recent destructive earthquakes in the Middle or Near East. Firstly, as the foreshock was felt and heeded by some but not all of the inhabitants, the geographical casualty distribution was not a reliable reflection of the local shaking intensity. Thus, casualties were low or nil in some villages near the epicentre which were completely destroyed but in which the population had slept ont of doors; and conversely, casualties were relatively high in some villages near the periphery of the epicentral region when the inhabitants had slept indoors. Secondly, the Salmas Plain contained a number of churches

(*) The road is here E-W, and the car was displaced sideways towards the isolated "bas-relief" monntain, i.e. northwards. Zayia $\left({ }^{22}\right)$ is more precise: "it (the car) was projected 0 m 50 sideways". 
Table 2 - EARTHQUAKE DAMAGE TO CIIURCIIES

N.B. Dates of several churches have not yet been eonfirmed. See also Fig. 5 .

\begin{tabular}{|c|c|c|c|}
\hline Village & Church & I) ate & Type \\
\hline Akhtekhaneh & Astlvadzadzin & 1342 , rest. 1891 & $\begin{array}{l}\text { rough stone masonry \& kiln } \\
\text { brick; } 3 \text { domes }\end{array}$ \\
\hline Aslanik & Sarkis & 1886 & \\
\hline Ayan & Asdvadzadzin & 1781 & sun-dried brick \\
\hline Derik & Asrivadzazin & 14th century & rough stone masonry \\
\hline Drishik & Sarkis & 1400 & stone masonry; domed \\
\hline Ghalasar & Sarkis & 1806 & rough stone masonry \\
\hline Gharabagh & Gevork & 1784 & rough stone masonry \\
\hline Ghezelja & $\begin{array}{l}\text { Hovanes } \\
\text { Boghos Petros }\end{array}$ & $1007 ?$ & $\begin{array}{l}\text { stone masonry } \\
\text { chapel: stone masonry? }\end{array}$ \\
\hline Gulizan & $\begin{array}{l}\text { Sarkis } \\
\text { "Assyrian" }\end{array}$ & & sun-dried brick \\
\hline Haftavan & $\begin{array}{l}\text { Gevork } \\
\text { Boghos }\end{array}$ & 13th century & $\begin{array}{l}\text { stone masonry; domed } \\
\text { kiln brick; domed }\end{array}$ \\
\hline & Asdvadzazin & & sun-dried brick \\
\hline & Thadeus & 13th century & sun-dried brick \\
\hline $\begin{array}{l}\text { Haqviran } \\
\text { Hodar }\end{array}$ & Sarkis & & \\
\hline $\begin{array}{l}\text { Chahriq } \\
\text { (Jarai) }\end{array}$ & $\begin{array}{l}\text { Gevork } \\
\text { "Assyrian", }\end{array}$ & 1203 & $\begin{array}{l}\text { rough stone masonry; "woo- } \\
\text { den " roof } \\
\text { rough stone masonry; barrel } \\
\text { vault roof }\end{array}$ \\
\hline Kalashan & Ifovanes & & $\begin{array}{l}\text { sun-dried brick; "wooden " } \\
\text { roof }\end{array}$ \\
\hline Khosrova & $\begin{array}{l}\text { Sarkis } \\
\text { Givargis } \\
\text { Mar Zaya } \\
\text { Liba Ghucha } \\
\text { Ishu } \\
\text { Brashemoil } \\
\text { Mary } \\
\text { Mar Yosseb }\end{array}$ & 1717 & $\begin{array}{l}\text { sun-dried brick; "wooden" } \\
\text { roof } \\
\text { stone masonry } \\
\text { kiln brick } \\
\text { kiln brick } \\
\text { chapel; sun-dried brick (open) } \\
\text { chapel; stone masonry } \\
\text { kiln brick }\end{array}$ \\
\hline
\end{tabular}




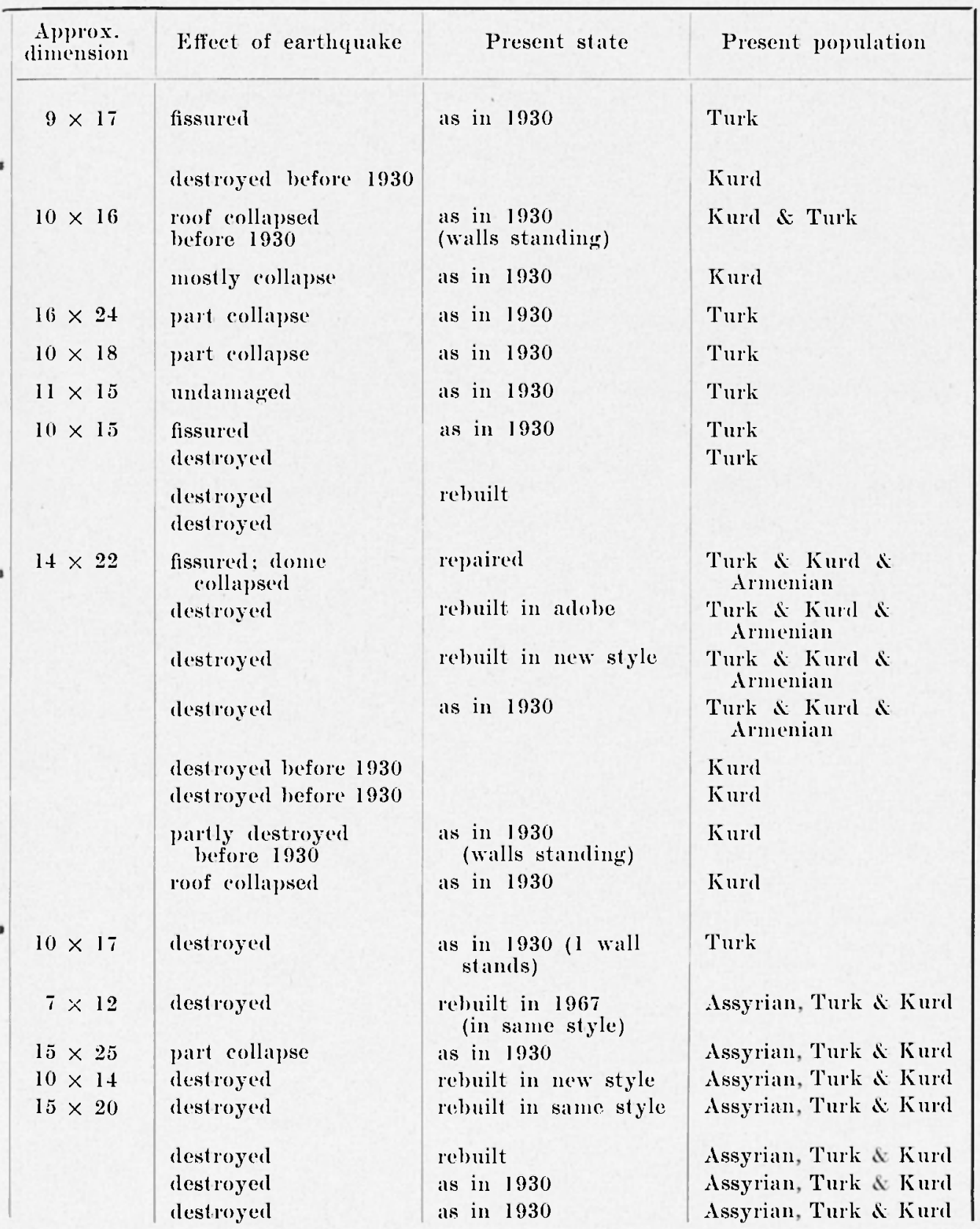




\begin{tabular}{|c|c|c|c|}
\hline Village & Chureli & Date & Туре \\
\hline $\begin{array}{l}\text { Kapek } \\
\text { (Kiabik) }\end{array}$ & Asdvadzadzin & & "wooden" roof \\
\hline Kohneh Shahr & $\begin{array}{l}\text { Hagol } \\
\text { Sarkis } \\
\text { Hovanes } \\
\text { Varar } \\
\text { Mar Ghoryagh }\end{array}$ & $\begin{array}{l}1671 \\
1671 \\
1825\end{array}$ & $\begin{array}{l}\text { stone masonry; "wooden" } \\
\text { roof? } \\
\text { stone masonry } \\
\text { sun-dried brick }\end{array}$ \\
\hline Mallam & $\begin{array}{l}\text { Zoravar } \\
\text { Gevork } \\
\text { Vartan }\end{array}$ & $\begin{array}{l}1641 \\
1711 \\
1724\end{array}$ & $\begin{array}{l}\text { stone masonry } \\
\text { sun-dried brick; flat roof } \\
\text { sun-dried brick; flat roof }\end{array}$ \\
\hline Patelivir & $\begin{array}{l}\text { Mar Yaghu } \\
\text { Mar Yukluana }\end{array}$ & & stone masonry \\
\hline Payajuk & Gevork & 1751 & stone masomry; domed \\
\hline $\begin{array}{l}\text { Sarmalek } \\
\text { (Sanamerik) }\end{array}$ & Sarkis & 1758 & stone masonry \\
\hline Sarmanava & & & $\begin{array}{l}\text { rougl stone masonry; vault } \\
\text { roof }\end{array}$ \\
\hline Sarnaq & $\begin{array}{l}\text { Asdvadzadzin } \\
\text { Mar Khinah } \\
\text { Hovanes }\end{array}$ & 1625 & $\begin{array}{l}\text { stone masonry } \\
\text { sun-dried brick; "wooden" } \\
\text { roof } \\
\text { sun-dried brick }\end{array}$ \\
\hline $\begin{array}{l}\text { Savran } \\
\text { (Sweh) }\end{array}$ & $\begin{array}{l}\text { Hovanes } \\
\text { Mat Mariam }\end{array}$ & 1200 & $\begin{array}{l}\text { stone masonry } \\
\text { stone masonry }\end{array}$ \\
\hline Sheytanava & Asdvadzatzin & 1708 & "wooden roof"" \\
\hline Vardan & $\begin{array}{l}\text { Sarkis } \\
\text { "Assyrian" } \\
\text { Asdvadzadzin }\end{array}$ & & $\begin{array}{l}\text { sun-dried brick; "wooden" } \\
\text { roof } \\
\text { sun-dried brick; domed } \\
\text { sun-dried brick; flat roof }\end{array}$ \\
\hline Zaviehjuk & $\begin{array}{l}\text { Prishad } \\
\quad \text { (Hazara } \\
\text { Pergiclu) } \\
\text { Hovanes }\end{array}$ & $1892 ?$ & $\begin{array}{l}\text { sun-dried brick; flat roof } \\
\text { sun-dried brick }\end{array}$ \\
\hline
\end{tabular}




\begin{tabular}{|c|c|c|c|}
\hline $\begin{array}{l}\text { Approx. } \\
\text { dimension }\end{array}$ & Effect of earthquake & Present state & Present population \\
\hline \multirow[b]{7}{*}{$16 \times 20$} & destroyed before 1930 & & Kurd \\
\hline & destroyed & rebuilt as a chapel & Turk \& Kurd \\
\hline & destroyed & as in 1930 & Turk \& Kurd \\
\hline & destroyed before 1930 & & Turk \& Kurd \\
\hline & destroyed & as in 1930 & Turk \& Kurd \\
\hline & desiroyed & rebuilt & Turk \& Kurd \\
\hline & desiroyed & $\begin{array}{l}\text { as in } 1930 \text { ( } 2 \text { walls } \\
\text { standing) }\end{array}$ & Armenian \& Kurd \\
\hline \multirow{2}{*}{$\begin{array}{l}9 \times 14 \\
7 \times 12\end{array}$} & destroyed & rebuilt same style & Armenian \& Kurd \\
\hline & destroyed & rebuilt in same style & Armenian \& Kurd \\
\hline $10 \times 20$ & $\begin{array}{l}\text { destroyed } \\
\text { destroyed by Turks } \\
\text { in } 1918\end{array}$ & rebuilt at new location & $\begin{array}{l}\text { Assyrian \& Kurd } \\
\text { Assyrian \& Kurd }\end{array}$ \\
\hline \multirow[t]{2}{*}{$13 \times 21$} & destroyed & as in 1930 & Armenian \& 'Turk \\
\hline & destroyed & as in 1930 & 'Turk \\
\hline $7 \times 17$ & undamaged & as in 1930 & Kurd \\
\hline $12 \times 20$ & part collapse & $\begin{array}{l}\text { as in } 1930 \text { (3 walls } \\
\text { slanding) }\end{array}$ & 'Turk \\
\hline \multirow[t]{2}{*}{$10 \times 13$} & part collapse & repaired & 'Turk \\
\hline & destroyed & as in 1930 & Turk \\
\hline \multirow[t]{6}{*}{$14 \times 17$} & destroyed & as in 1930 & Turk \\
\hline & destroyed & $\begin{array}{l}\text { rebuilt in sun-dried } \\
\text { brick }\end{array}$ & Turk \\
\hline & destroyed & as in 1930 & uninhabited \\
\hline & destroyed & as in 1930 & Kurd \\
\hline & destroyed & as in 1930 & Kurd \\
\hline & $\begin{array}{l}\text { part collapse before } \\
1930\end{array}$ & & Turk \\
\hline \multirow[t]{2}{*}{$8 \times 10$} & undanaged & as in 1930 & Kurd \& Turk \\
\hline & destroyed & as in 1930 & Kurd \& 'lurk \\
\hline
\end{tabular}


which, even thomgh not all of uniform construction, were nevertheless much more resistant than the usual adobe house. Many of these churches can be seen to-day in the same condition as after the earthquake, and they provide a unicue means of assessing the serelity of the shock near the epicentre.

The effect of the earthruake on the villages of the salmas Plain is described first, and followed by the description of the momntain villages and the isolated pocket of damage near Mamalan south of the epicentral region.

\section{a) Salmas Plain.}

The region of maximum clestruction, located in the southwestern part of the Salmas Plain, is approximately contained in the imaginary triangle with apexes at Kohneh Shahr, Payajuk and Zaviehjuk (Fig. 3). Here all the houses were completely levelled to the gromnd. The most intense destruction probably occurred near the kohneh Shahr apex where all but one of the 20 churches located in the villages of Kohneh Shahr, Savra, Khosrova, Uleh, Malham, Gulizan and Patehvir were completely destroyed. The exception was Mar Givargis in Khosrova, a large stone, masonry structure with walls built in the traditional style, i.e. about $1.25 \mathrm{~m}$ thick, with an outer layer of hewn stone and an inner layer of rough stone and with good cement mortar. The $t$ inner pillars and the vaulted roof collapsed, but most of the walls excepting the corners of the building remained standing (Fig. 5). In Malham, which, with Saramerik, was the only Christian village in which most of the inhabitants slept indoors and consepuenty sulfered a large number of (asualties (*), the southern and eastern walls of $S$. Zorarar - a construction similar to Mar Givargis - remained partly standing, but the rest of the church collapsed (Fig. 6). All the other 18 chumches, which inclucled at least $f$ stone masonry and 3 kiln-brick constructions, were destroyed to the extent that none of the walls remained, even partly, standing. The medieval Miri-Khatun brick tower and the great mosque of Kohneh Shahr were similarly destroyed.

(*) The reader is referred to Table I for casualty figures which are not mentioned systematically in the text. 


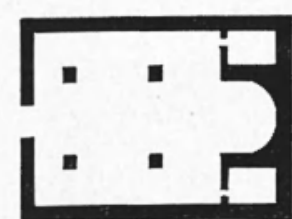

SAVRAN S. Hovanes

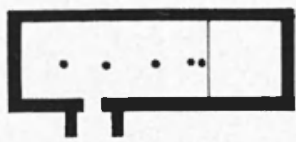

SAVRAN Mat Marlam

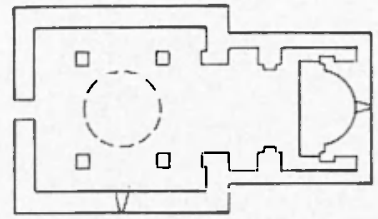

HAFTAVAN S. Gevork

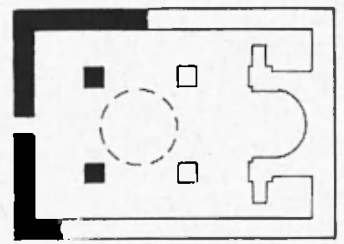

DRISHIK S. Sarkis

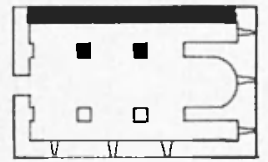

GHALASAR S.Sarkis

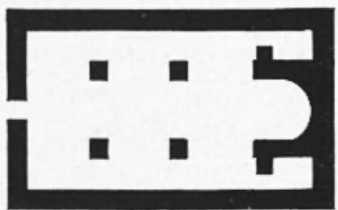

PAYAJUK S. Gevork

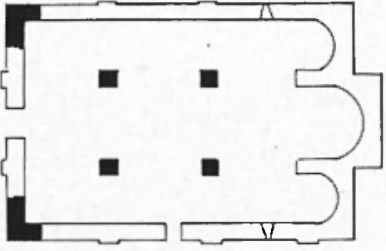

KHOSROWA Mar Givargis

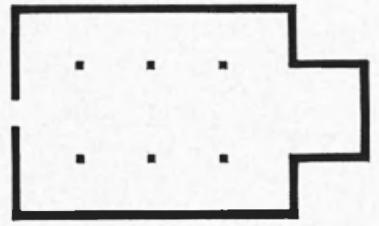

KHOSROWA Liba Ghucha Ishu

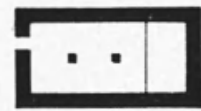

KHOSROWA S Sarkis
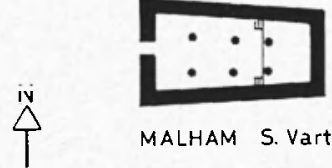

MALHAM S. Vartan

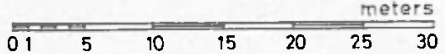

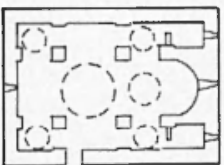

GHARABAGH S. Gevork

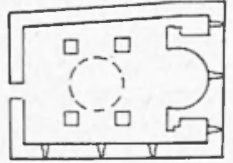

GHEZELJA S. Hovanes

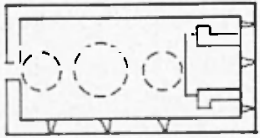

AKHTEKHANEH S. Asvadzaz in

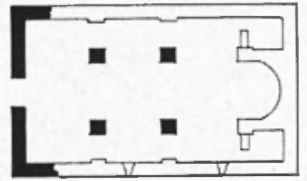

SARNAQ S. Asvadzazin

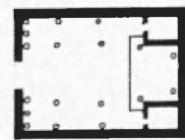

SARNAQ Mar Khinah

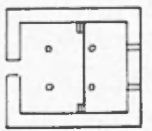

ZAVIEJUK S.Prishad

Fig. 5 - Earthquake Damage to churches in the salmas Platy Features shown in black collapsed during the earthquake. Fround plans are schematic. See also Table 2 and Kleiss (1969). 


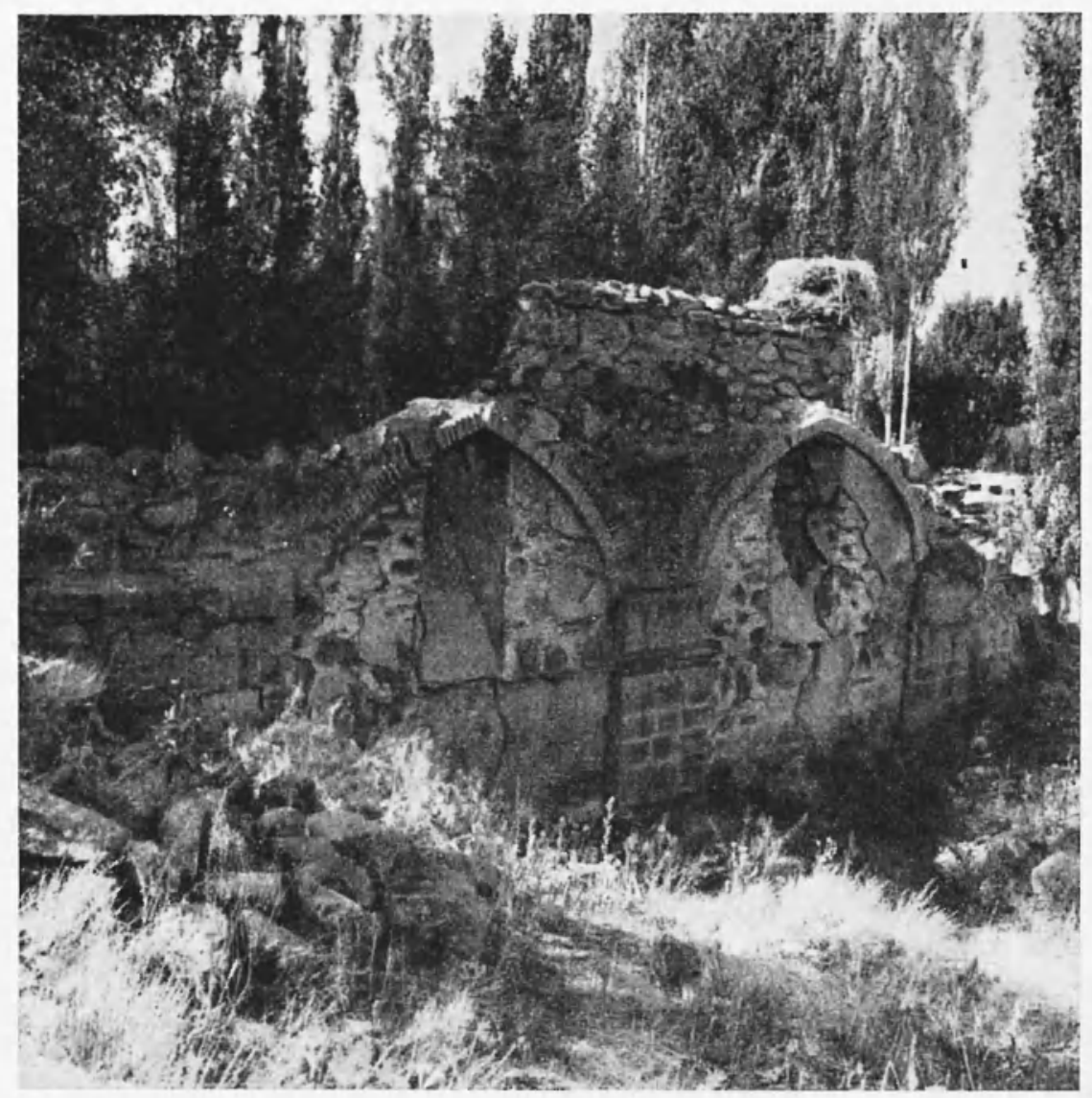

Fig. 6 - S. Zoravar (Matilam)

Interior side of southern wall seen from the partly collapsed eastem wall (lower left-hand corner). The roof and all other walls collapsed.

The intensity of ground motion in this region of maximum destruction is also indicated by the risplacement of tombstones in the cemeteries of Khosrova, Haftavan and Malham. These, tombstones, sculpter in the local basalt, are generally marle of two separate pieces, a horizontal slab typically about $30 \mathrm{~cm}$ thick and $80 \times 185 \mathrm{~cm}$ in plan, placed on the ground above the grave, and a solicl block about $66 \mathrm{~cm}$ high and $60 \times 160 \mathrm{~cm}$ in plan, placed on the slab (Figs 7 and 8). The slab is generally partly lodged in the ground, but it was impossible to ascertain so many years after the event whether it had mover relatively to the ground during the earthquake. The upper block 


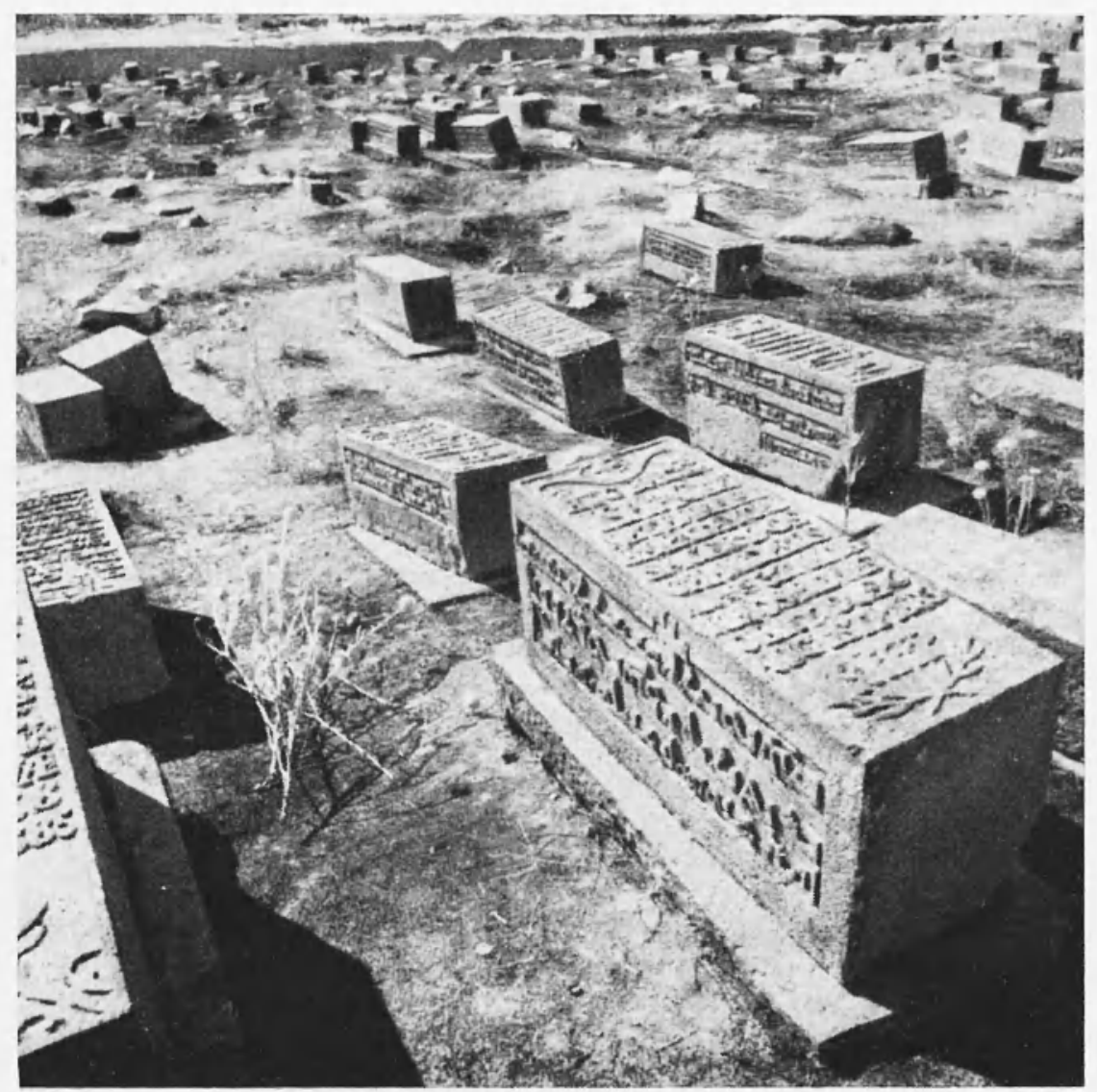

Fig. 7 - TOMBSTONES IN KHOSROVA CEMETERY

In the forcground, some examples of rotation of the upper block with respect to the lower ground slab. Note some tilted tombstones in the background. Looking NW.

harl howevor, in nearly all cases, mover from its original position on the slab. In the Khosrova cemetery, 183 cases of movement (about $1 / 3$ all the tombstones) were clear enough to be measured: they showed 104 rotations ( 74 anti-clockwise and 30 clockwise), 55 N-S translations (40 to the $\mathrm{N}, 15$ to the $\mathrm{S}$ ) and $28 \mathrm{E}-\mathrm{W}$ translations (23 to the $\mathrm{E}, 5$ to the W). As most of the cases of rotation did not seem to be accompanied by any $\mathrm{E}-\mathrm{W}$ translation, they were probably due to a $\mathrm{N}-\mathrm{S}$ or S-N sliding with unequal friction at the slab-rock interface. Examples of tombstone movement are given in Fig. 7 and 8 and their 


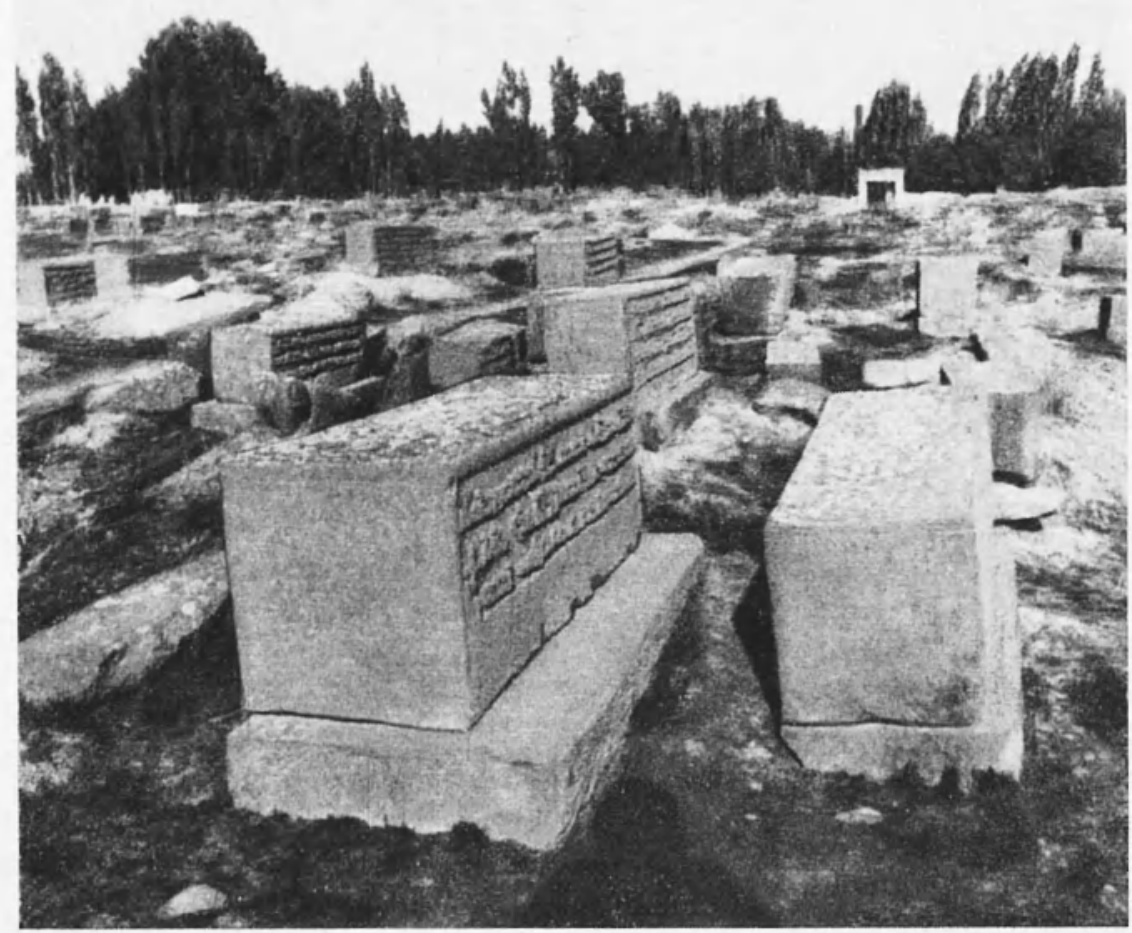

Fig. S - ToMBstrones IX KuOSROVA CEMETERY

Fxamples of translation of the upper block with respect to the gromol slab. Jooking $W$.

locations are shown in Fig. 9. A number of tombstones (not included in the above comt) were also tilted sideways, generally to the $\mathrm{X}$ or to the $\mathrm{S}$ and often without any visible displacement of the block on its slab, probably as a result of fomdation failure under the slab. The Khosiova cemetery is located about $4 \mathrm{~km}$ from the earthquake fault, the latter being oriented $\mathrm{NW}$-SE and of right-lateral displacement with the Nis side downthrown.

$B y$ an unusual coincidence, Zayia, the eyewitness of the main shock, not only observed the displaced tombstones in Khosrova the morning after the earthquake, but actually saw them move again during the principal aftershock of 8 May. "You know the tombstone of M. Darnis, one of the most massive of all the cemetery; it measures about $2 \mathrm{~m}$ in length, $0.60 \mathrm{~m}$ in width and $0.75 \mathrm{~m}$ in height. Well, 


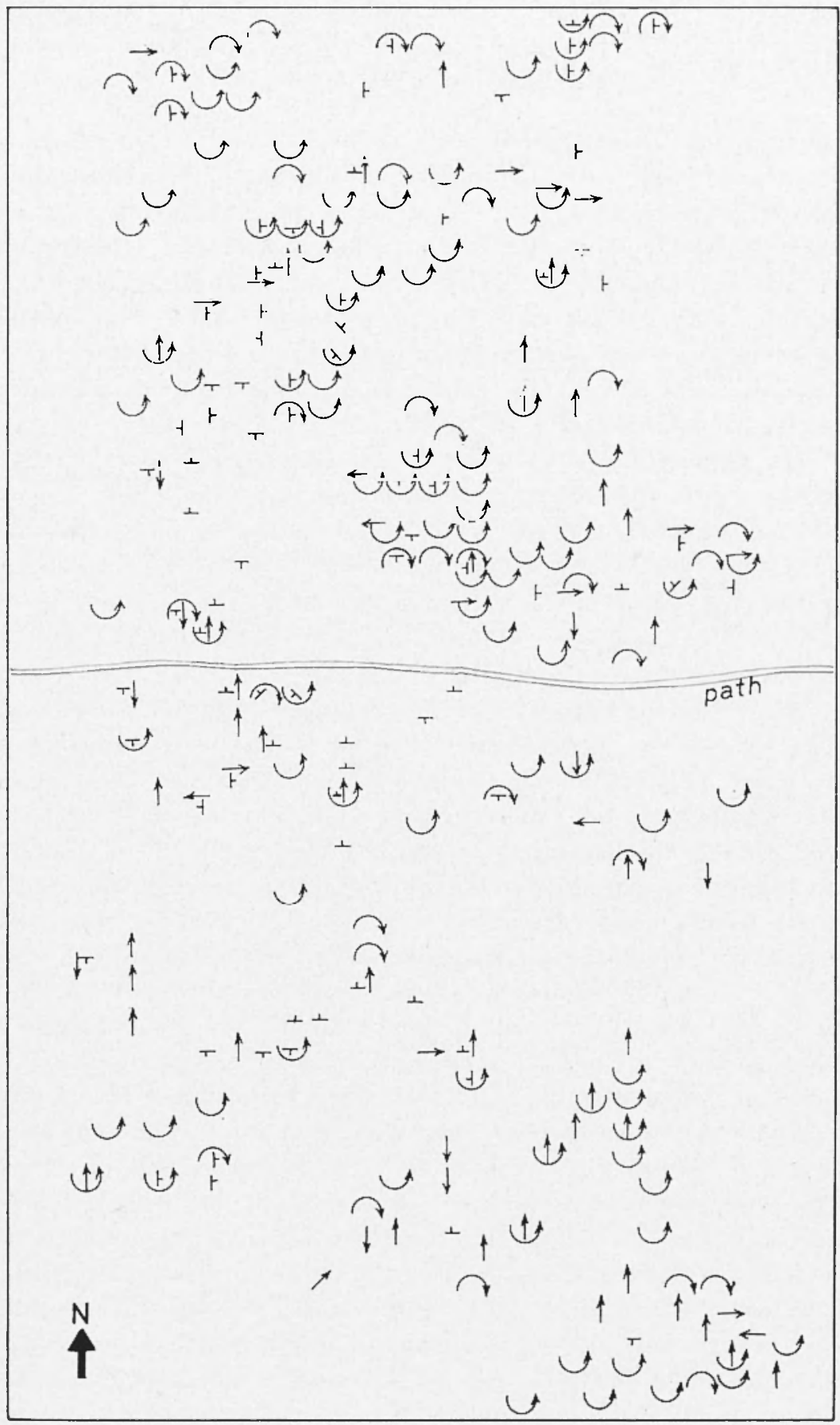

Fig. 9 - DIsplaced toubstones IN KuOSROVA CEMLTERY

Sketch-plan showing approximate location of displaced tombstones. Arrows indicate movement of upper block with respect to ground slab; tilted tombstones shown with geological dip symbol. Justaposed symbols describe overall displacement of single tombstones. Tombstones showing no movement, or ambiguous cases, are onitted. Width of eemetery is approxima- 
this enormous stone was projected about $0.50 \mathrm{~m}$ from the south to the north; it is no longer on the grave. The same happened to most of the other lombstones" (-). "Thursiay evening at about $6 \mathrm{pm}$, I was sitting on Mr. Baduel's tombstone in the (Khosrova) cemetery and was reciting the rosary to replace the breviary which I hadn't been able to say, when I felt myself being lifted; all the other tombstones creakerl. I didn't even get up but watched the other tombstones being lifterl: by about $3 \mathrm{~cm}$. The Resurection of the Dead came into my mind and onto my lips" (21).

The Malham cemetery which is crossed by the earthquake fault, contains only a few tombstones of the type described above, the majority being male of a single piece. Of the few that could be measured, several cases of translation were observed in which the mpper block was moved in the same direction as the fault side on which it was located, i.e. to the $E$ on the north sicle of the fault, and to the $W$ on the south side of the fault (Fig. 10).

Several independant witnesses amongst the survivors of the earthquake, as well as contempolary written accounts, related that, in the region of maximum destruction, a first shock was felt as an upward motion, and that this was followed immerliately by a horizonlal shock flom W to E and then by another one from E to W. In many churches, we cbserver that the central pillars or columms and the western facarle collapsed towarls the west. Iikewise, in many of the less damaged churches in the region east of the epicentre (described below) only the western wall collapsed, and this always to the west. However, as the eastern end of these churches is usually formed by one or three apses, it is the most resistant regarlless of the direction of strong ground motion. Other similar observations must first be obtained from other earthquakes before conclusions may be drawn.

In the Salmas Plain east of the region clescribed above, but still in the Kohneh Shahr-Payajuk-Zaviehjuk triangle, the destruction was nearly as severe. In I ilman, the largest settlement of the whole region, it was estimated that about 1,100 of the 18,000 inhabitants were killed, constituting probably a large number of those that slept incloors. These casualty figures are however unreliable, due to two main reasons. Firstly, the size of the town: whereas in the smaller villages, people could remember, sometimes even by name, all those that had been killed, in the larger centres of Dilman and, to a lesser degree, Kohneh Shahr, the surviving inhabitants found it difficult to grasp the overall extent of the catastrophe. Seconclly, the absence 


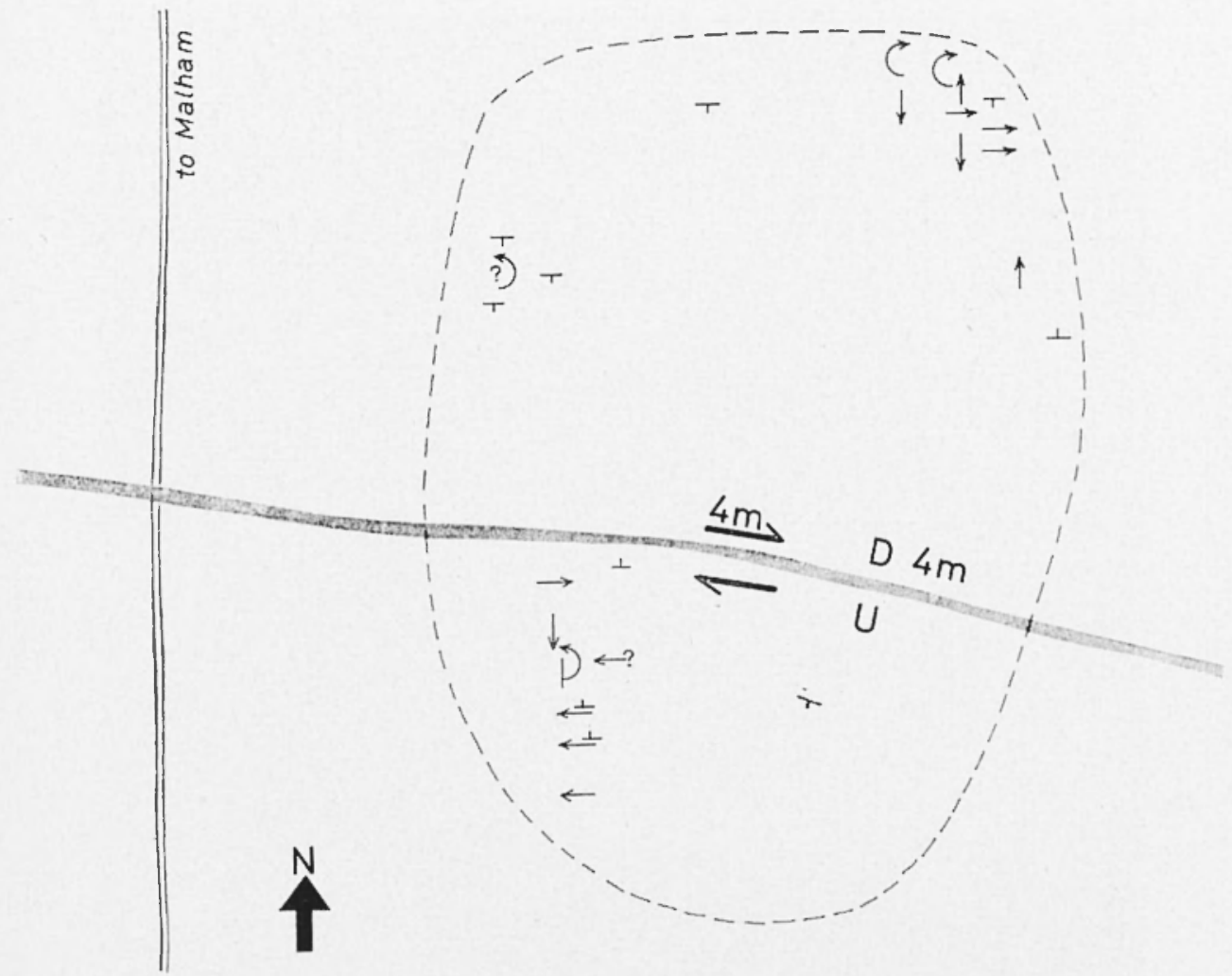

Fig. 10 - DISPLACED TOMBSTONES IN MAI.IIAI CEMETERY

Only a small number of the tombstones were of the block on slab" type. Symbols are as for Fig. 9. Dashed line is approximate boundary of cemetery which measure about $75 \mathrm{~m}$ in the N-S direction. Shaded line is earthquake fault scarp with displacements in meters $\left(\mathrm{C}_{-}=u p, \mathrm{D}\right)=$ down).

of a Christian community in Dilman: in the other Christian villages, the various massacres and persecutions that this minority had undergone in the decales preceding 1930 , male them acutely aware of their numbers both before and after the earthquake, and several chroniclers came from Tehran and Tabriz to investigate and record the facts $\left(^{9,15}\right)$. Nothing similar seems to have been undertaken in Dilman or in the entirely Kurdish or Turkish settlements.

All the buildings in the town of Dilman, including the large Agha Mosque, were destroyed, with the exception of two newly built houses which were still standing, even though severely damaged. The town 
Was subseguently rebuilt west of the ruins and remamed Slabhum. The othere villages in the regrion of meximum destruction not described ao far were Haftavan. Sarmaq. Drishik, Kuche Mashk, Kalashan, Zaviehjuk and Payjuk. In Haftaran, two of the three churches were destroperl, the surviror being lhe 13th century church of $\mathrm{s}$. Gerork. The centril dome of this massive construction collapsed and the extern facde develinged diagonsel fissures, but otherwise the builnling was intact (Fig. 11). The neably school and asiombly hall, built in kiln-brick with a stone fomnditicn, collapsed. In Sarnaq,

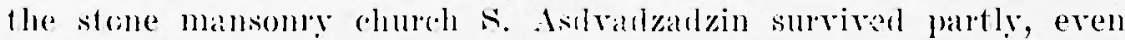

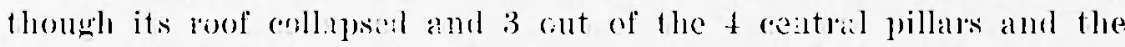
western facode fell to the west (Fig. 12). A similar rhureh in Drishik, s. Sarkis, suffereal much the same type of damage, and the andobe

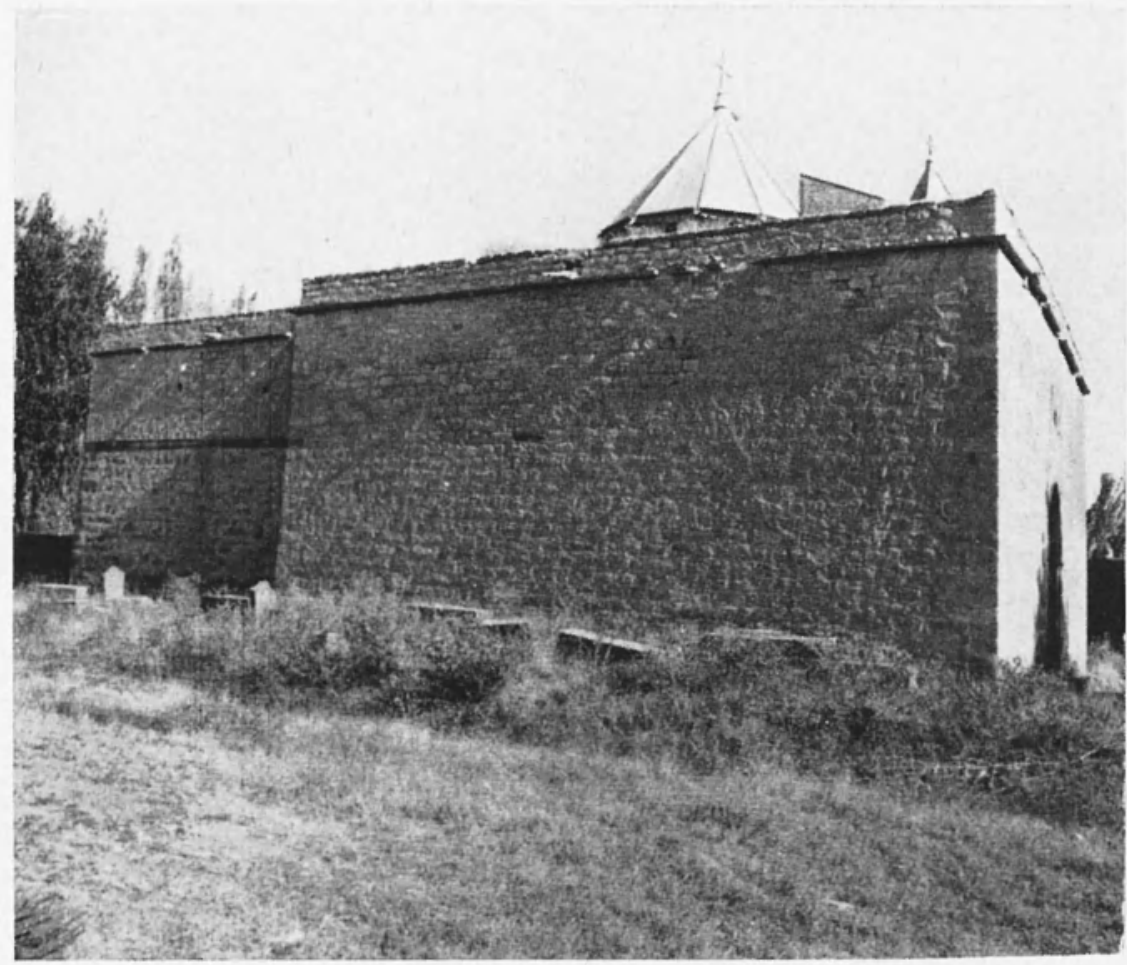

Fig. 11 - S. Gevork (Haftavax)

The central dome collapsed, and the eastern and northern walls (seen here) were fissured, but otherwise this 13 th e. chureh withstood the earthquake remarkably well. 


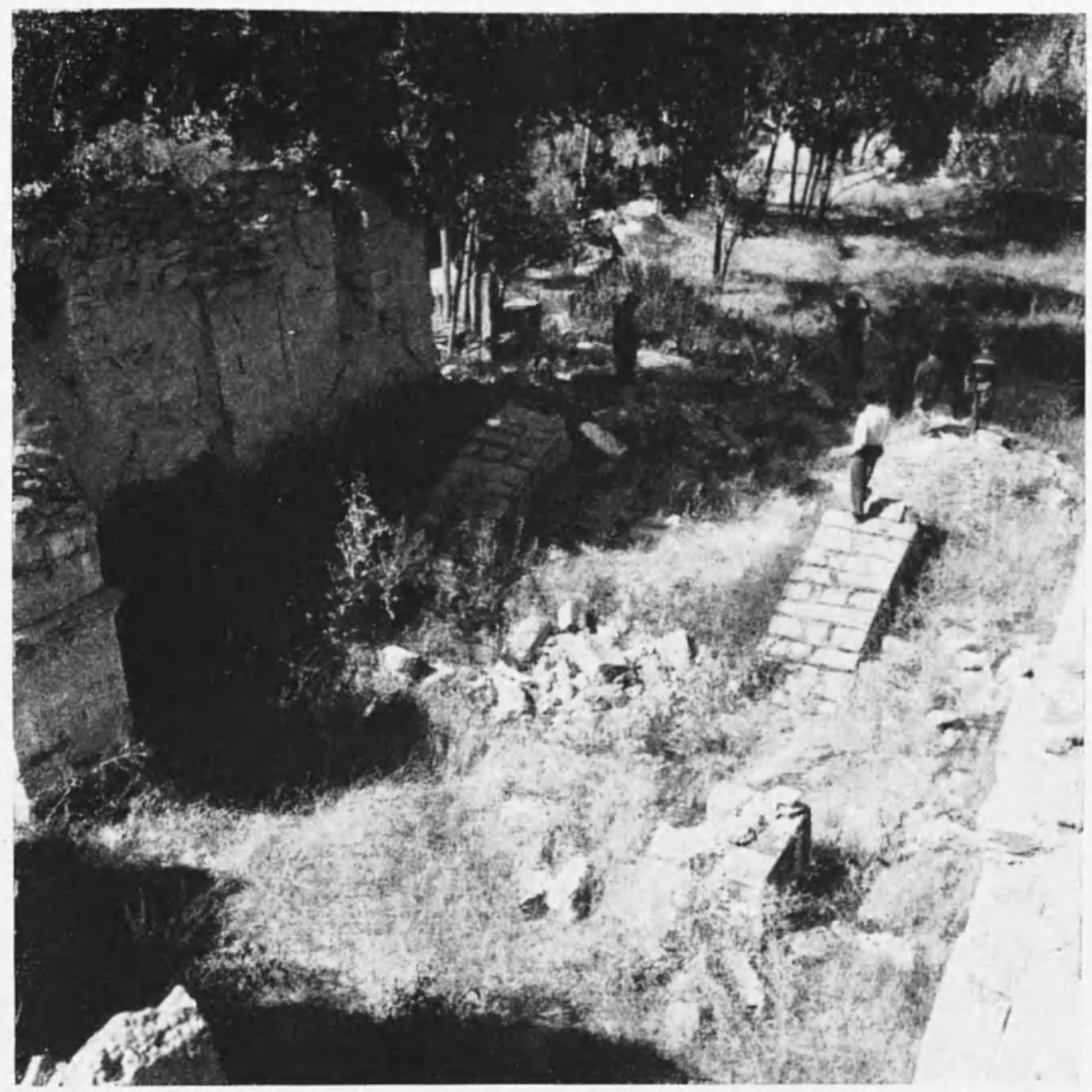

Fig. 12 - S. AsDyadzanzs (Sarsag)

The westem wall and 3 of the 4 central pillars foll to the west, a type of damage common to many of the salmas churches. Interior of the church seen from the castern apse.

church in Kalashan was destroyed except for one wall which remained partly standing.

Zaviehjuk is of particular interest as it is situated on the fault at the southern edge of the Salmas Plain. The village, and the arbobe church of $S$. Hovanes were destroyed, but the abobe chapel of S. Prisham was completely intact. The latter is situated on rock, about $500 \mathrm{~m}$ west of the village and at about the same distance south of the fault. In plan it is nearly square $(8 \times 10 \mathrm{~m})$ and its flat roof is makle of poplar trunks as beams and covered with a mul/straw mix- 
ture. The only effect of the earthquake that could be detected was that the 4 tree-trunk pillars supporting the roof were leaning by about 30 to the east (Fig. 13), i.e. opposite to the damaged churches north of the fault which were generally leaning, or had collapsed, to the west. The survival of this building located nearly on the fault may be attributed in part to the fact that it was a compact, quasi-cubic structure, built on rock and near the southeastern limit of destruction. Wven though this does not explain entirely its exceptional resistance,

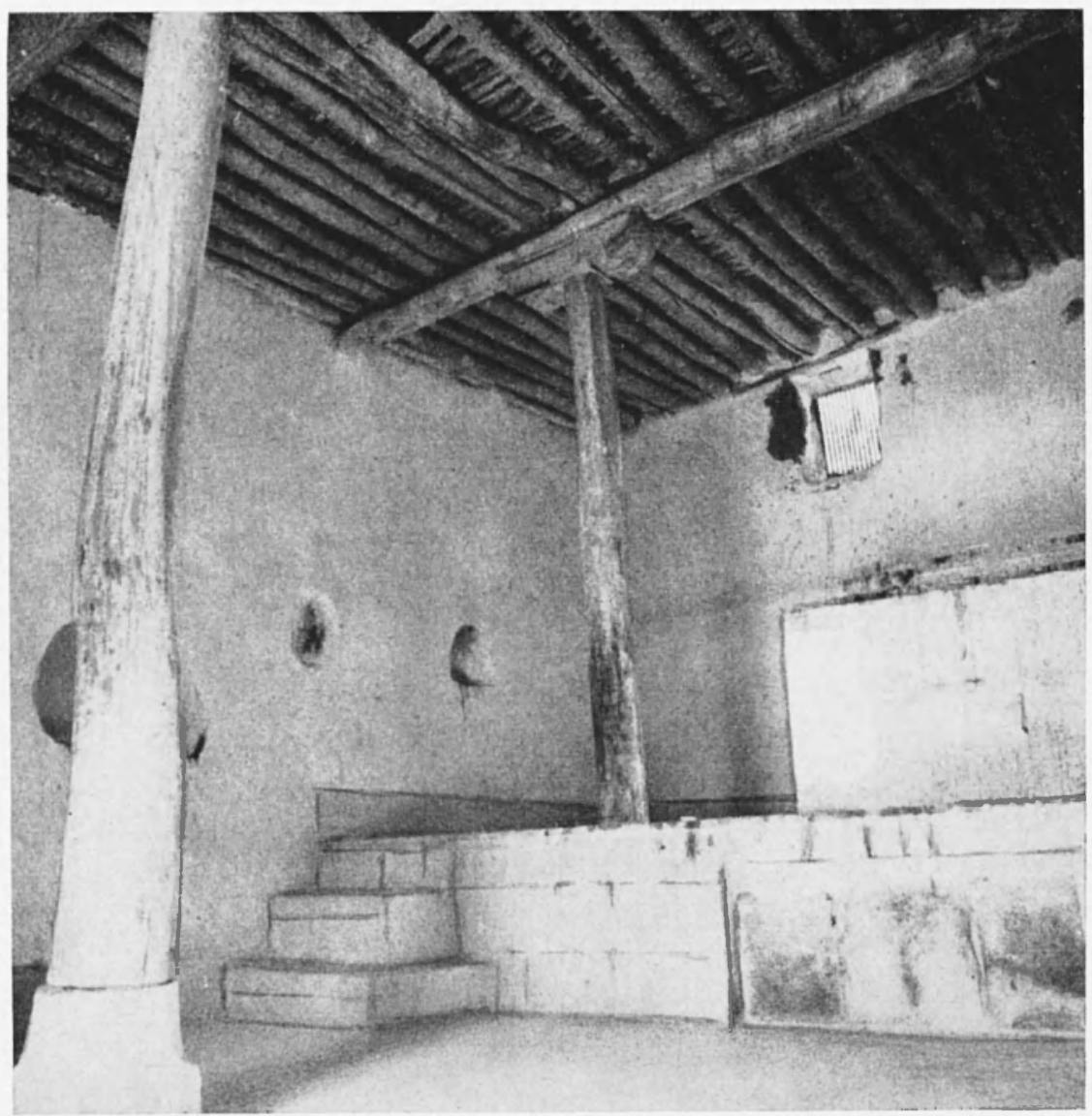

Fig. 13 - S. Prisilad (NeAr ZavieirJuk)

The only visible earthquake damage to this adobe chapel located about $500 \mathrm{~m}$ sonth of the Salmas Fault was that all 4 tree trunk pillars were leaning slightitly to the east. 
it does place $\mathbf{S}$. Prishad in the same category as other undamaged structures located on, or very near, other earthquake faults (13).

In Payajuk, about $3 \mathrm{~km}$ due east of Dilman, destruction was still very severe, killing the only three inhabitants who slept indoors. The stone masonry church of S. Gevork was levelled to the ground, as was the near-by house of the Armenian writer and poet Rafi (Fig. 14). The new village was subsequently relocated south of the previous one.

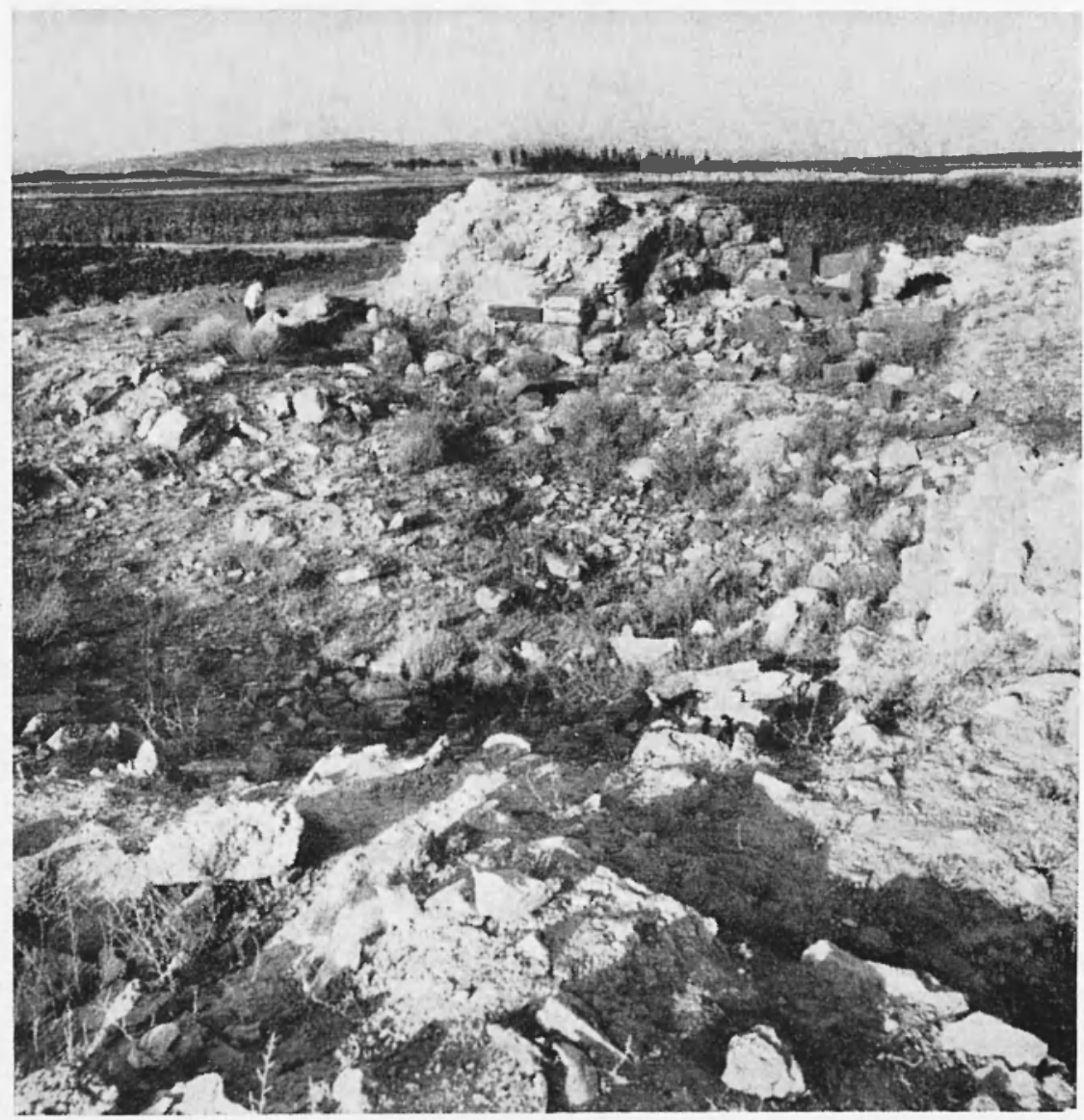

Fig. 14 - S. Gevork (PAYAJUK)

The church collapsed completely. View from the southeast corner towards the apse. 


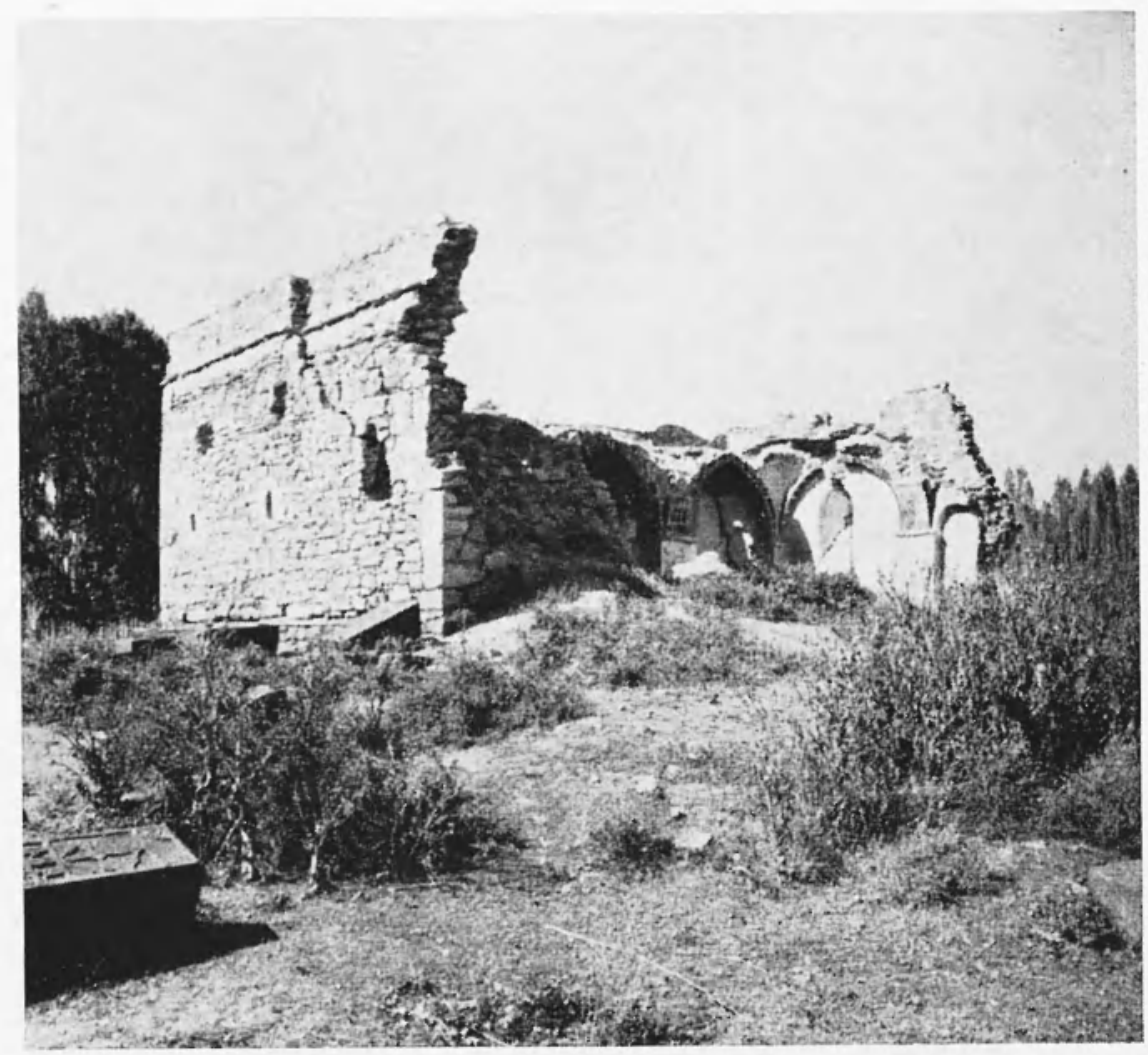

Fig. 15 - S. SARKis (Gimatasar)

Part of the roof, and the northern wall, collapsed to the north. Looking SW.

The other villages destroyed in the Salmas Plain but locater outside of the triangle of maximum destruction (Kohneh Shahr-PayajukZaviehjuk) were Moghanjik and Saramerik in the north, Sadaghian, Hamzehkandi, Habashi, Ghezelja, Ghalasar and Akhtekhaneh in the east, Minas, Khantakhti and Tamar in the southeast. All these villages were restroyed and suffered casualties, but the state of the three stone masonry churches of the region in Ghalasar, Akhtekhaneh and Ghezelja, indicated that the shaking was here probably less severe. In Ghalasar, the roof of S. Sarkis collapserl partly, and the northern wall fell to the north, but the other walls survived at their full height (Fig. 15). This collapse towards the north, also observer for the small parapet wall sturounding the roof of the church, is exceptional, and 


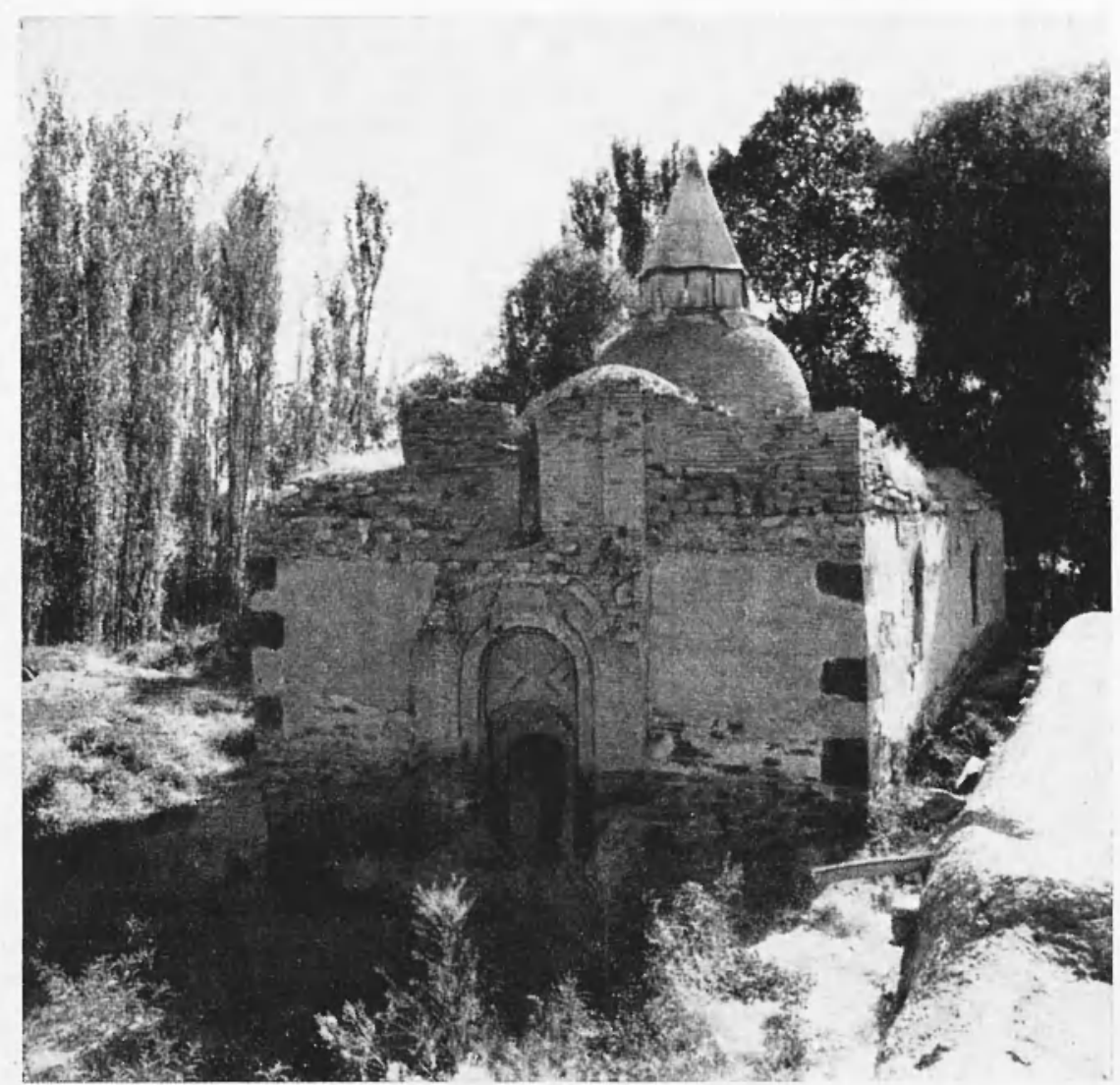

Fig. 16 - S. Asdvadzadzin (AkiltekHaneit)

The 14th c. church, located near the eastern limit of the epicentral region was only fissured by the earthquake.

may be compared to the dominant northward displacement of the tombstones in Khosrova (p. 171) and the northward shift of Zayia's car (p. 160). The church of S. Asdvadzadzin in Akhtekhaneh survived entirely even though it was fissured (Fig. 16). It is a 14th century construction with the traditional double wall (kiln-brick inside, rough stone masonry outside), and a roof with three kiln-brick domes. The northern and eastern walls were fissured, and the interior $\mathrm{N}$-S arches developed cracks near their keystone (Fig. 17). In the near-by village of Ghezelja, S. Hovanes also survived, even though with more damage than S. Astvadzadzin (Fig. 18). This church, which we dated 


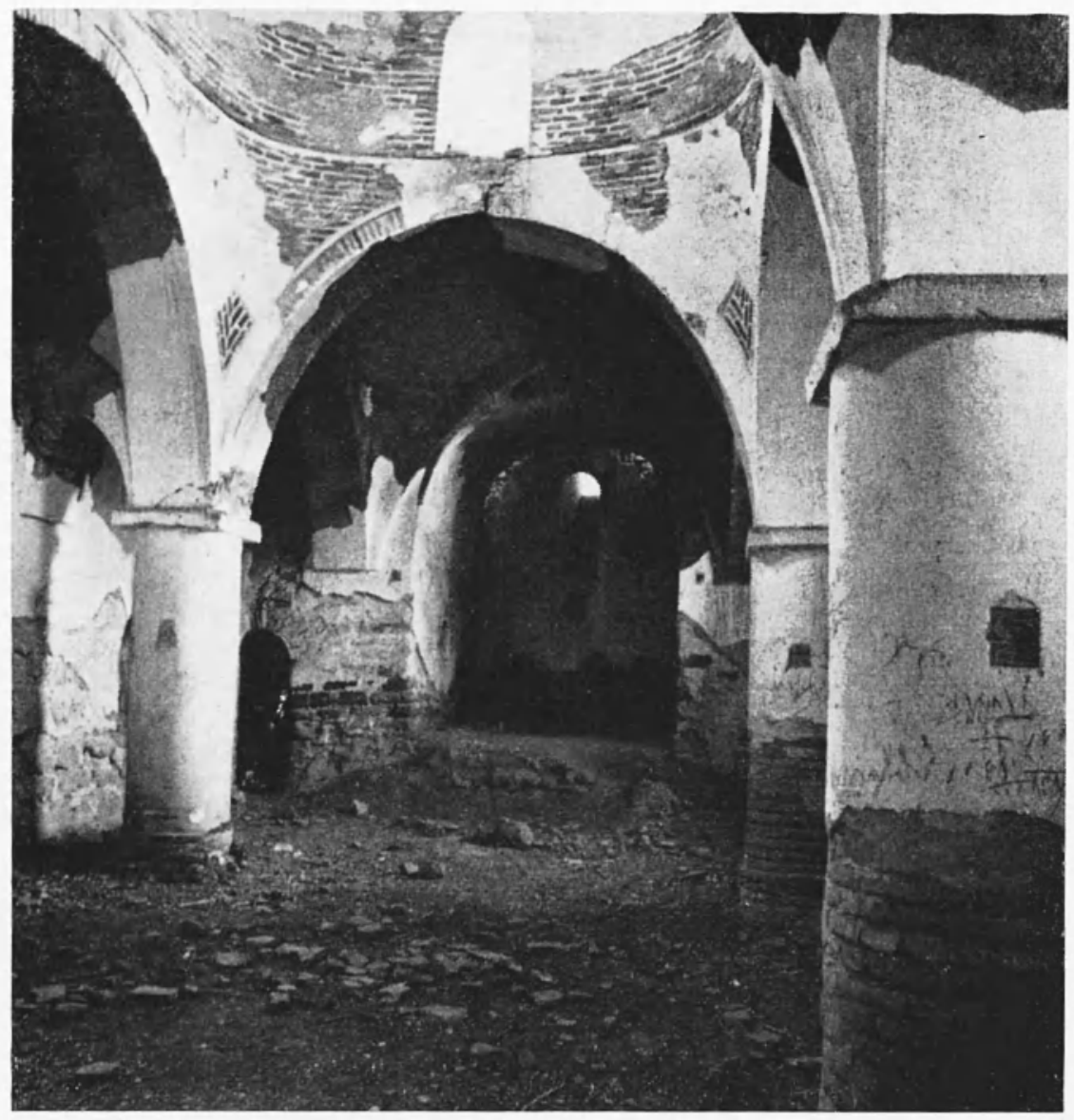

Jig. 17 - S. AsDVADzadzin (ARITTSKIANEII)

The main interior damage was a central east-west fissure crossing the length of the building.

provisionally 1007 A.D. by an inseription on the doorway, is a rough stone masonry construction with 4 pillars supporting a central dome. All four walls were fissured diagonaly, and an important central crack crossed the whole roof from it to W (Fig. 19).

The lesser damage suffered by the three churches in Ghalasar, Akhteklameh and Ghezelja described above when compared to all other churches of the Salmas Plain (with the exception of S. Gevork in Haftavan) leark one to situate in their vicinity the eastern limit of the epicentral region. Further east, towards Lake Rezayeh, ramage 


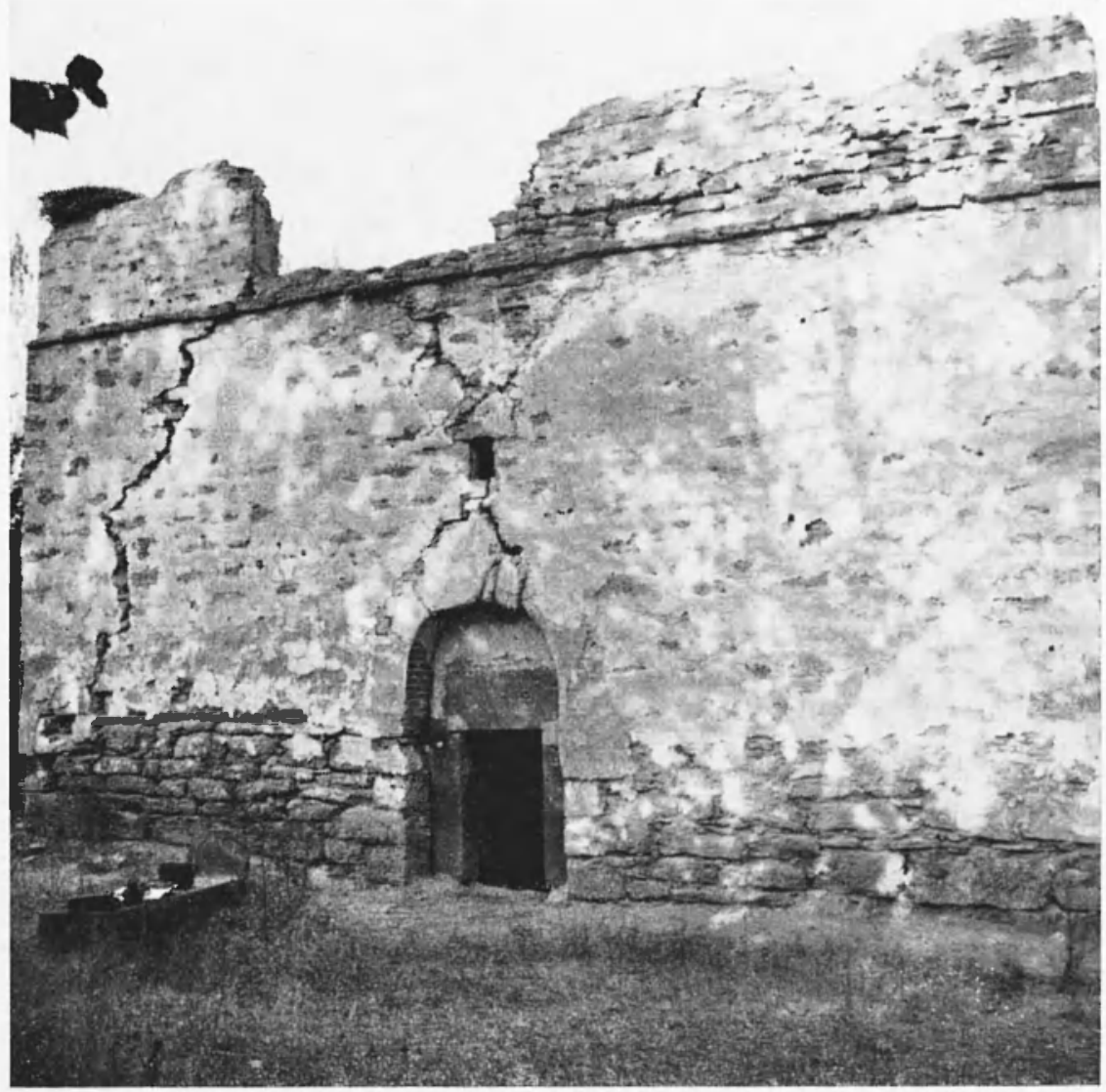

Fig. 18 - S. Hovanes (GIIEzeluA)

Eastern façade of the earliest dated church (1007 A.D.) in the Salmas Plain. All walls were serionsly fissured.

decreased very rapidly: Kanyan, Mafi Kandi, Shekar Yazi, Sultan Dhmed, Yavshanli, Gharaqeshlagh, and Aqziarat suffered little and had no casualties. Still further east, S. Gevork in Gharabagh, a church similar in plan and size to $\mathrm{S}$. Hovanes (Ghezelja), showed no signs of earthquake damage (Figr. 20).

\section{b) Mountain region.}

About half the number of villages damaged or destroped by the earthquake were situated in the mountains which surround the Salmas 
plain in the north, west and south. However, with the exception of Chahriy on the Zola Chay River, these villages were all smaller than those of the Plain. They were populated then (1930), as they are now, by Turks and Kurds, their Christian population having fled in 1918. For convenience of rescription, the region is subdivirled into a northern sector east of the Dowshivan Su, a western sector between the Dowshivan Su and the Zola Chay, and a southern sector east of the Zola Chay (Fig. 3).

In the north, the villages nearest to the Plain were destroyed and harl casualties: Vardan, Ayan, Ghabrabarl, Sheyran, Yengijeh and Isashgaran. Sailab and Howdar were partly destroyed with very

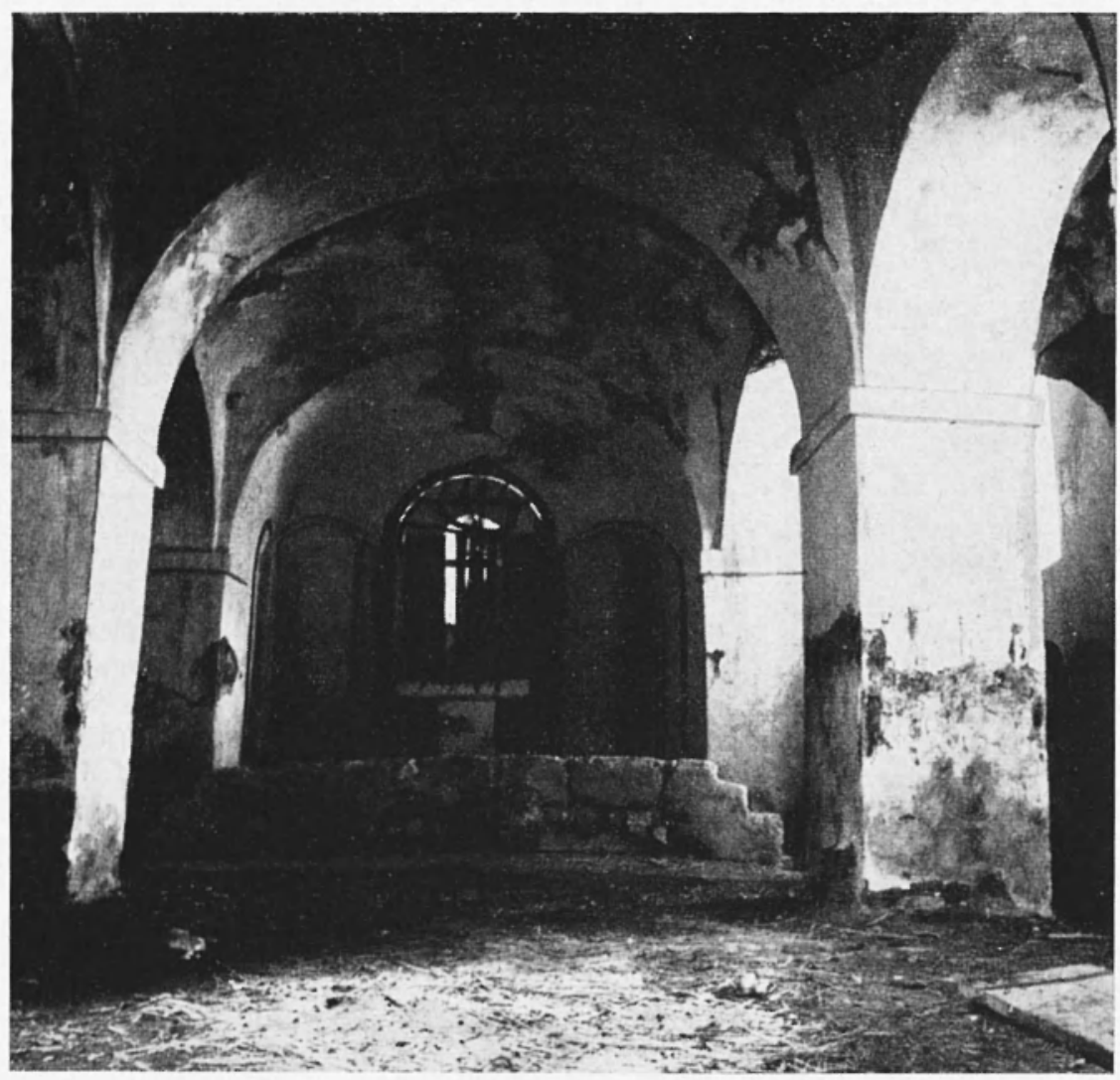

Fig. 19 - S. Ilovanes (Ghezelda)

As in Akhtekhaneh, the main interior damage was a central east-west crack crossing the whole building. 
few or no casualties, the latter being abandonned after the earthquake and resisted in a more accessible location (Fig. 21). Further north, Shurik, Urban, Gulan and Chahar Sutun which were only slightly damaged, mark the limit of the region of destruction.

In the western sector along the Zola Chay, Zola was destroyed, and most of the houses in Chahriq collapsed. In the latter village, of the two stone churches, one had been destroyed before 1930 and the other collapsed during the earthquake. Further upstream, Balghazan and Siavan were only partly damaged. North of the Zola,

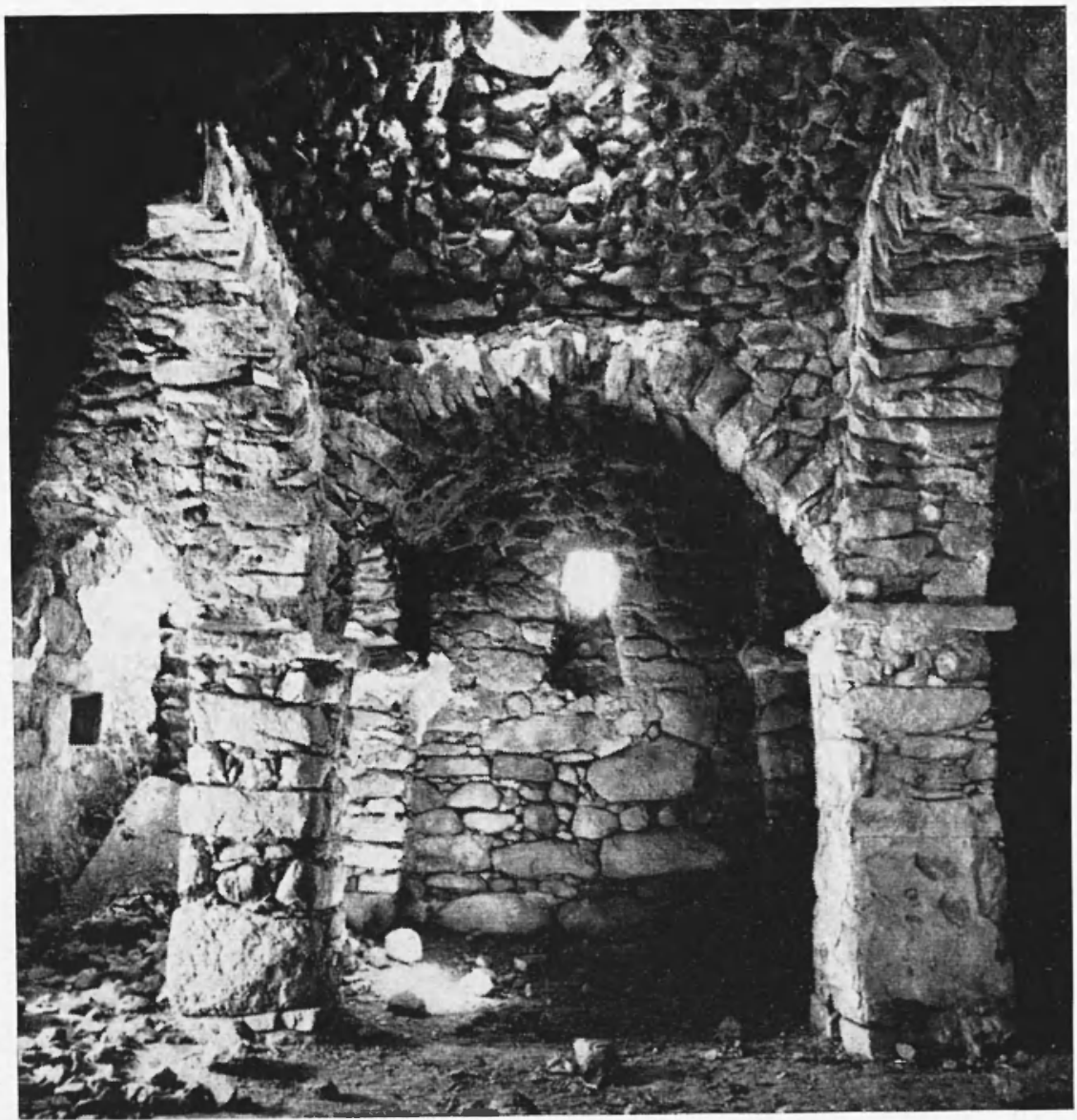

Fig. 20 - S. Gevork (Gilarabagit)

The church (1784 A.D.), located east of the epicentral region (sce Fig. 1), was unaffected by the earthquake. 


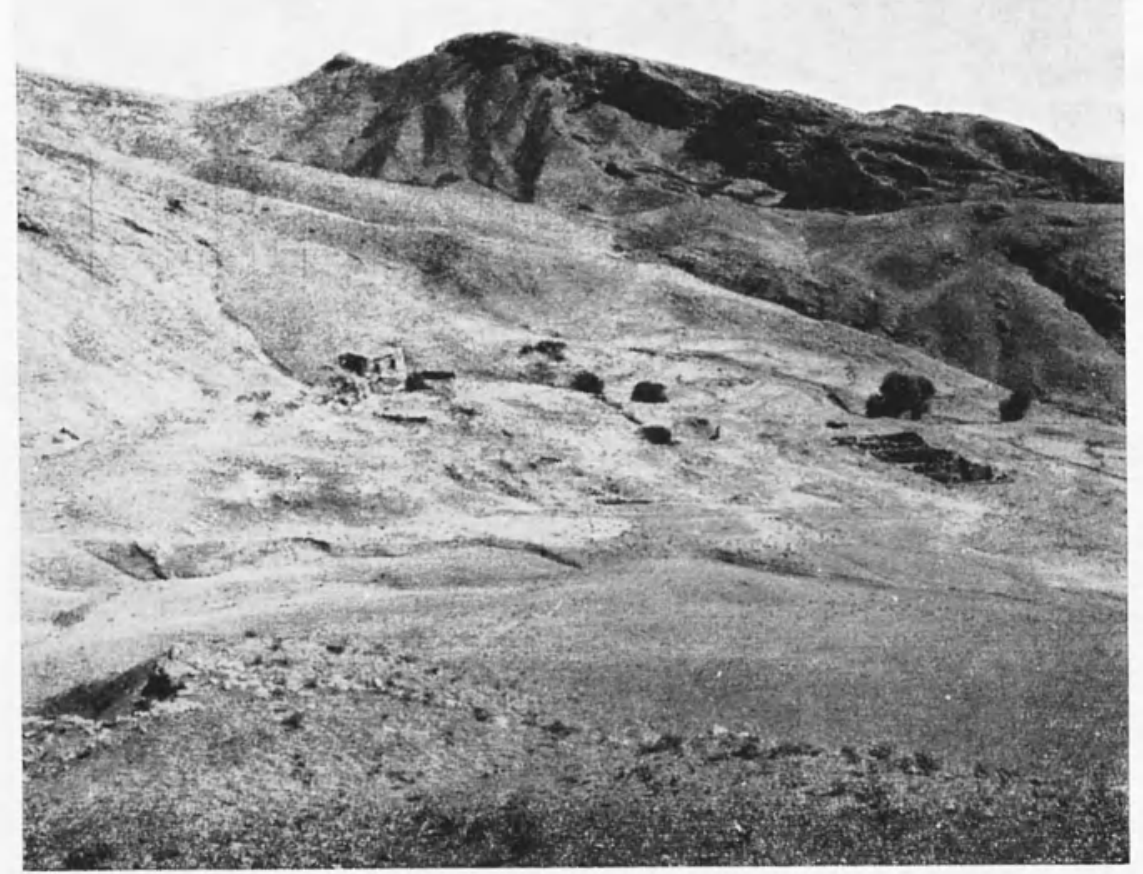

Fig. 21 - Site of HowdaR

One of several mountain villages destroyed by the earthquake and to-day relocated at a different site. Looking NE.

a line of villages on the basalt platean overlooking the Salmas Plain were destroyed and had a large proportion of casualties: Kahriz, Kurdran, Aslanik, and Haqviran. The churches in the last two localities had been destroyed before the earthquake when the Christians left the region. Along the Dowshivan Su, Nazirabarl, Sowfiabarl and Derik were completely destroyed and had heavy casualties, and in the latter two cases, were relocated at new sites. Above the old village of Derik, which had been sold to the Kurds before the earthquake, a small stone masonry chapel forming part of a monastery, collapsed (Fig. 22). A group of villages locater further up in the mountains were also destroyed: Guzik, Ashnak, Hablaran, Khorkhora, Senji and Alibolagh. 
The limits of destruction of this western sector can be traced approximately east of the Turkey-Iram border. The furthest village to be destroyed was Borushqalan where the casualties were exceptionally heavy because the foreshock had not been felt. Indirect information from Hanik in Turkey would suggest that the village had been partly damaged. Further south in Iran, dqbarzeh and Ghezel Kandi were only about half-destroyed. The villages in the extreme southwest are practically inacessible due to the difficulty of the terrain. However, by interviewing some of their inhabitants who had moved nearer to the Salmas Plain after the earthquake, we could establish that Shiveh Darreh, Shiveh, Dikeh and Haji Jafan were undamaged.

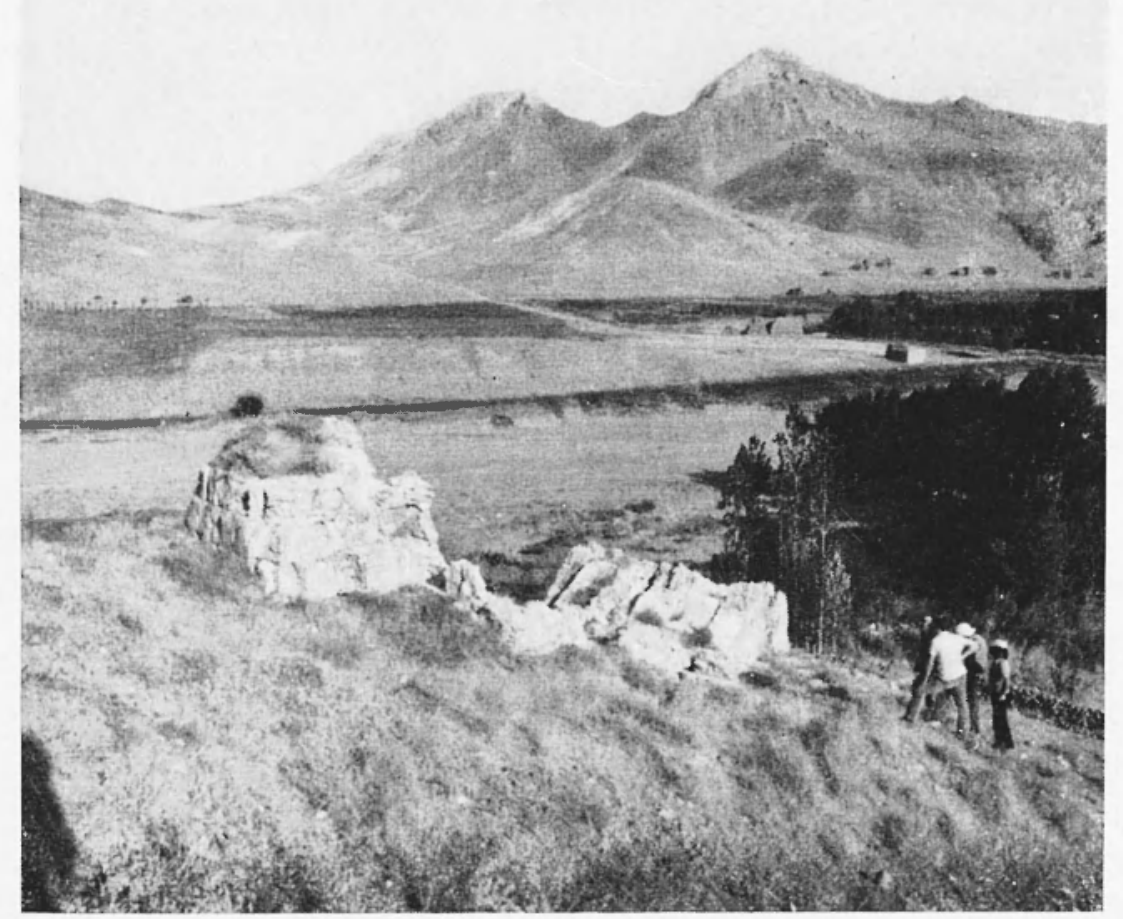

Fig. 22 - S. Asdvadzaizin (Derik)

The western part of the chapel collapsed, leaving only the apse standing. The old village, totally destroyed, was situated at the foot of the chapel.

The present-day village is located near the trees in the background. Looking SE. 
In Kashkavich, only 3 houses out of 20 collapser, killing 2 people, the rest being damager but standing. The heavy destruction in Kuzerash seems to have been rlue to some exceptional local condition (landslide?).

In the southern sector, Shurgel, locater on rock at the southeastern end of the earthquake fault, was about $1 / 3$ destroyed, and further along the fault alignment, Zindasht and Issy Su were only lightly damaged. In the south, Bardian and Bostakabad were also lightly damaged, but the adjoining villages of Gonieh, Bajergeh and Hosseinabar were unaffected.

c) Mamaqan pocket of destruction.

Apart from the main region of restruction in the Salmas Plain and in the surrounding mountains, isolated pockets of ramage occurred in a few regions away from the epicentre. Contemporary newspaper reports mention clamage in the Qutur valley south of Khoy, but we were as yet unable to investigate this information. South of the epicentral region, 85 people were killed in Mamaqan which was completely rlestroyed, even though all the surrounding villages (Bajergeh, Hosseinabar, Sidan, Mingol, etc.) were undamaged. Mamaqan is situated in a loess valley which has a very shallow water table. South of Mamaqan, Sormanava was half-restroyed, but its vaulted church situated on rock west of the village was undamaged. In both villages of Mamaqan and Sormanava all the inhabitants had slept. indoors as the foreshock had been felt only very lightly, and aftershocks did not increases appreciably the damage caused by the main event.

FALITIX( AND) THERMAL SPRIN(; ACTIVTY

\section{General.}

Two fault-breaks were associated with the earthquake: the first, termed here Salmas Fault, occurred in a NW-SE direction at the southern erlge of the Salmas Plain; the second, termed Derik Fault, occurred in a NE-SW direction near the mountain village of Derik (Fig. 3). Maximum displacements on these faults were: for the Salmas Fault, $4 \mathrm{~m}$ right-lateral and over $5 \mathrm{~m}$ vertical (NE downthrown); for 
the Derik Fault, left-lateral by an unknown amount, and about $1 \mathrm{~m}$ vertical (XW downthrown). Both faults were briefly alluded to in contemporary reports and correspondence: Franssen (`), Zayia $\left({ }^{21,22}\right)$, Brunk (3), Tabriz and Haratch newspapers; to-day they are still perfectly visible on the ground and on aerial photographs.

Related to this faulting, several thermal springs changed their locations or outputs: Darmanad spring (Issy Su) in the sontheastern extension of the Salmas Fault, Derik spring in the southwestern extension of the Derik Fault. A new spring, the Zelzele Bolaghi (literally, the earthquake spring), appeared in the Salmas Plain and is still responding to-clay to local earthquake tremors.

\section{Salmas Fault.}

The Salmas Fault is the longer of the 2 faults, and the one that produced the larger displacements. It is formed by two separate en echelon segments referred to here as the Akhian segment and the Zaviehjuk segment, the latter being probably the result of the junction of two other en echelon segments (Fig. 23).

The Akhian segment starts at the Shurgel pass and follows the erlge of the mountain, crossing the village of Akhian, and then disappears as it enters the Salmas Plain near Sarnaq (Fig. 24). Maximum displacements are $1.5 \mathrm{~m}$ (NE down). The slight curvature of the fault trace when referred to the local topography indicates a stee] north dip of the fault plane at depth. At Akhian, the fault trace crosses a stream bet, exposing a shear zone in the underlying metamorphic rock and in which many new earthquake fissures can be seen crossing olrler joints and slickensided planes. A surface travertine cover about $1 \mathrm{~m}$ thick is interrupted at the elge of the fault zone. East of Mkhian, and at about $500 \mathrm{~m}$ from the fault, a short $\mathrm{N} 160^{\circ}$ fracture zone in the travertine cover is marle of open en echelon fissures 20 to $30 \mathrm{~m}$ long and oriented about $\mathrm{N} 140^{\circ}$, and occasional ridges oriented about $\mathrm{N} 20^{\circ}$ (Fig. 25). This disposition suggests local left-lateral shearing, probably conjugate with respect to the Salmas Fault.

The Zaviehjuk segment starts east of the village of Zaviehjuk and crosses its northern outskirts, striking $\mathrm{N} 125^{\circ}$ (Fig. 26). Its throw ( $\mathrm{NE}$ (lown), about $2 \mathrm{~m}$ at the village (Fig. 27), increases in the west to over $5 \mathrm{~m}$ (Fig. 28). Its strike changes gradually from the original N $125^{\circ}$ to $N 105^{\circ}$ at the Malham cemetery. Up to this location it is entirely contained in the alluvial fans which originate in the moun- 


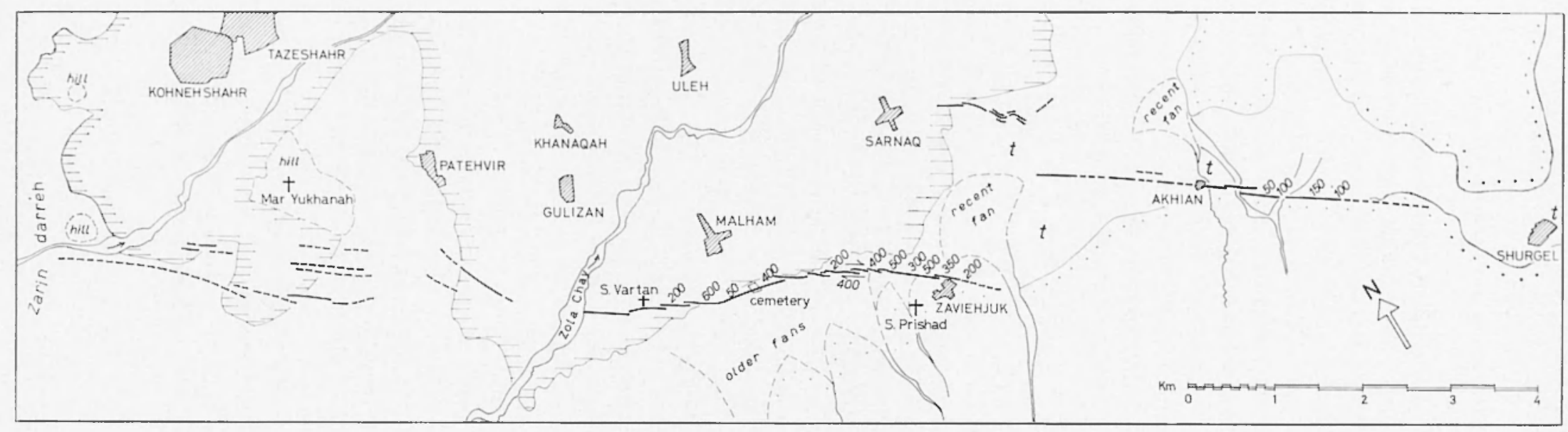

Fig. 23 - Salmas Fault

The trace of the earthquake fault, dashed where uncertain, was drawn in the field with the help of $1: 20,000$ aerial photographs. Numbers indieate vertical displacement (NE downthrown) in centimeters; horizontal displacement was right-lateral,but could be measured precisely in only one location. Dotted shading is rock onterop, line shading is cultivated fields. t, travertine cover. 
tains to the south. About half-way between Zaviehjuk and the Malham cemetery, two narrow parallel gullies were displaced right-laterally by about $4 \mathrm{~m}$. Even though other reliable markers for measuring horizontal novement could not be found, the overall trace of this segment is composed of characteristic right-lateral scarps oriented at about $20^{\circ}$ to the overall strike (Fig. 29). The sides of the erosion gullies which have worked their way into the degraded scarp since 1930

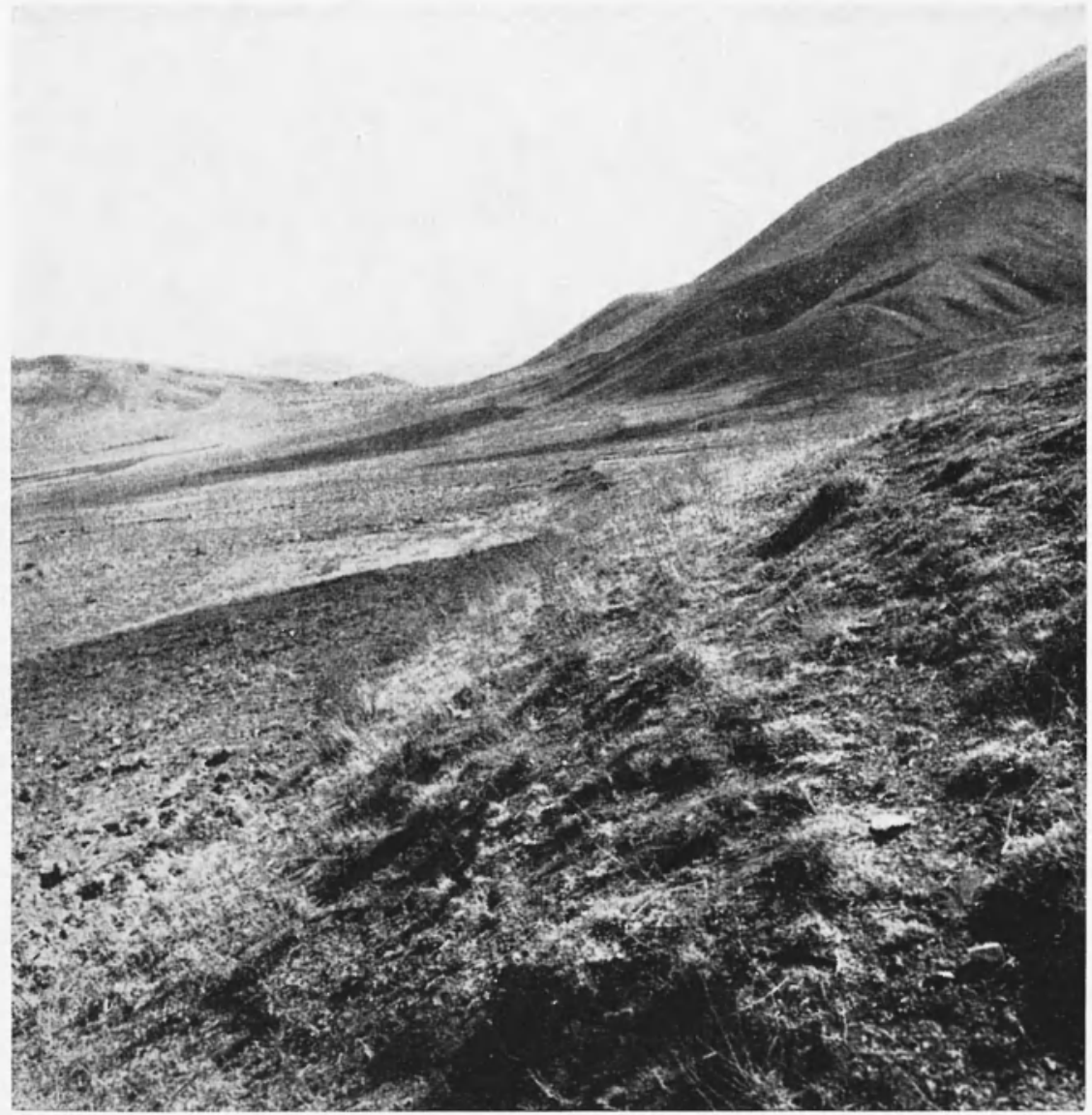

Fig. 24 - Salmas fault, Akmia segment

The eroded fault trace runs at the foot of the mountain, from the lower right-hand corner of the photograph to the shurgel pass in the background. Average vertical displacement (NE, i.c. left side, down) was about $1 \mathrm{~m}$. Looking SE. 


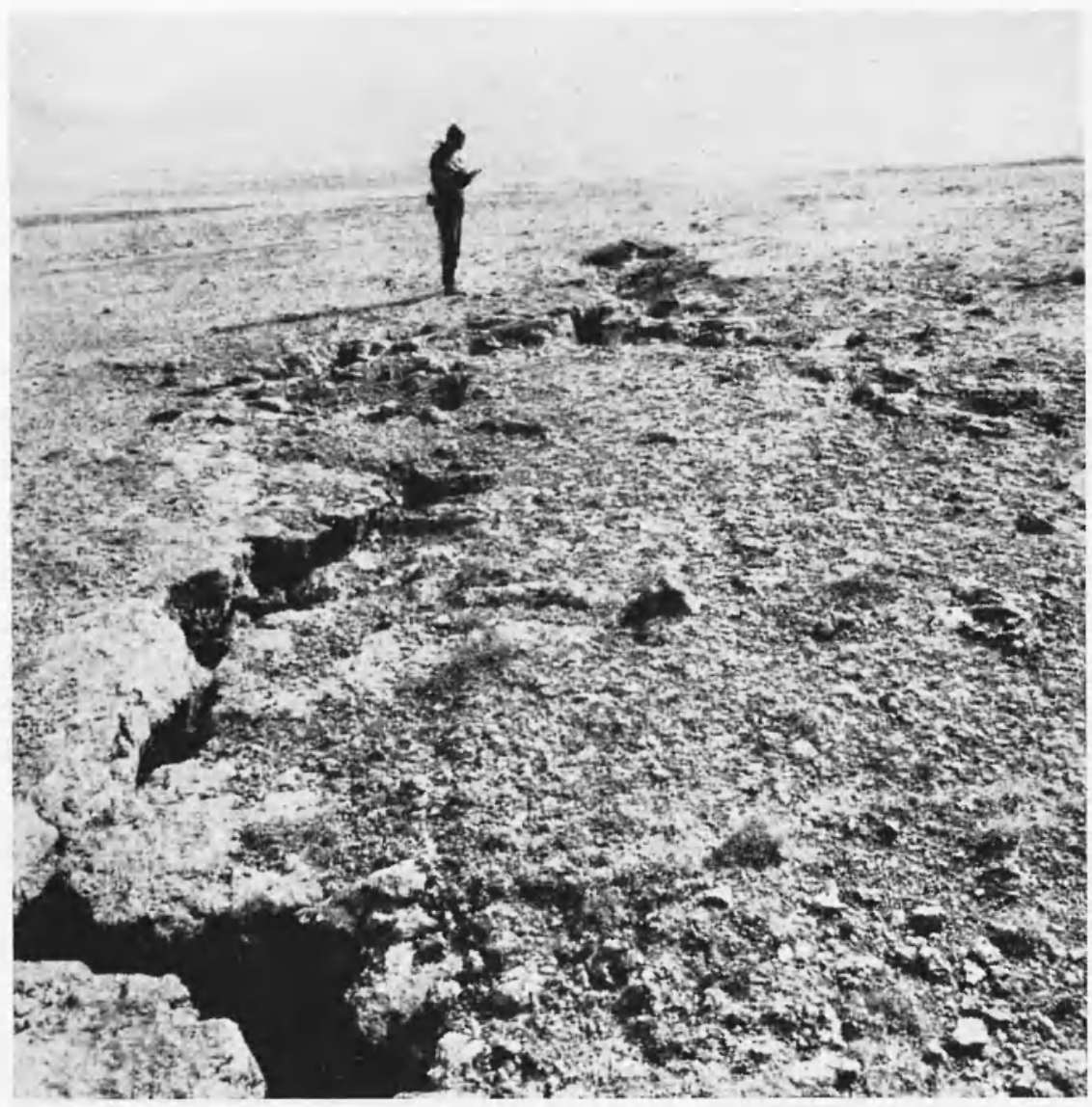

Fig. 25 - Salmas mauli, Akmian segment

Fracture zone in the travertine cover east of Akhian, about $500 \mathrm{~m}$ from the main fault trace. The en echelon pattern suggests local left-lateral shearing. Looking SE.

show an undisturbed bedrling of the gravel fans, with occasional small fissures parallel to the scarp and dipping north by about $85^{\circ}$.

$\Delta$ the Malham cemetery, the fault shows clearly a feature observer at several localities, i.e. a narrow graben located immediately at the foot of the degraded scarp (Figs 30 and 31). This increases the apparent throw from about 2.5 , to over $4 \mathrm{~m}$, and suggests a tensional type of fracturing. Contemporary descriptions of the scarp after the earthquake also mention a vertical wall with a deep open crack at its base, and expulsion of water along its trace. West of the 


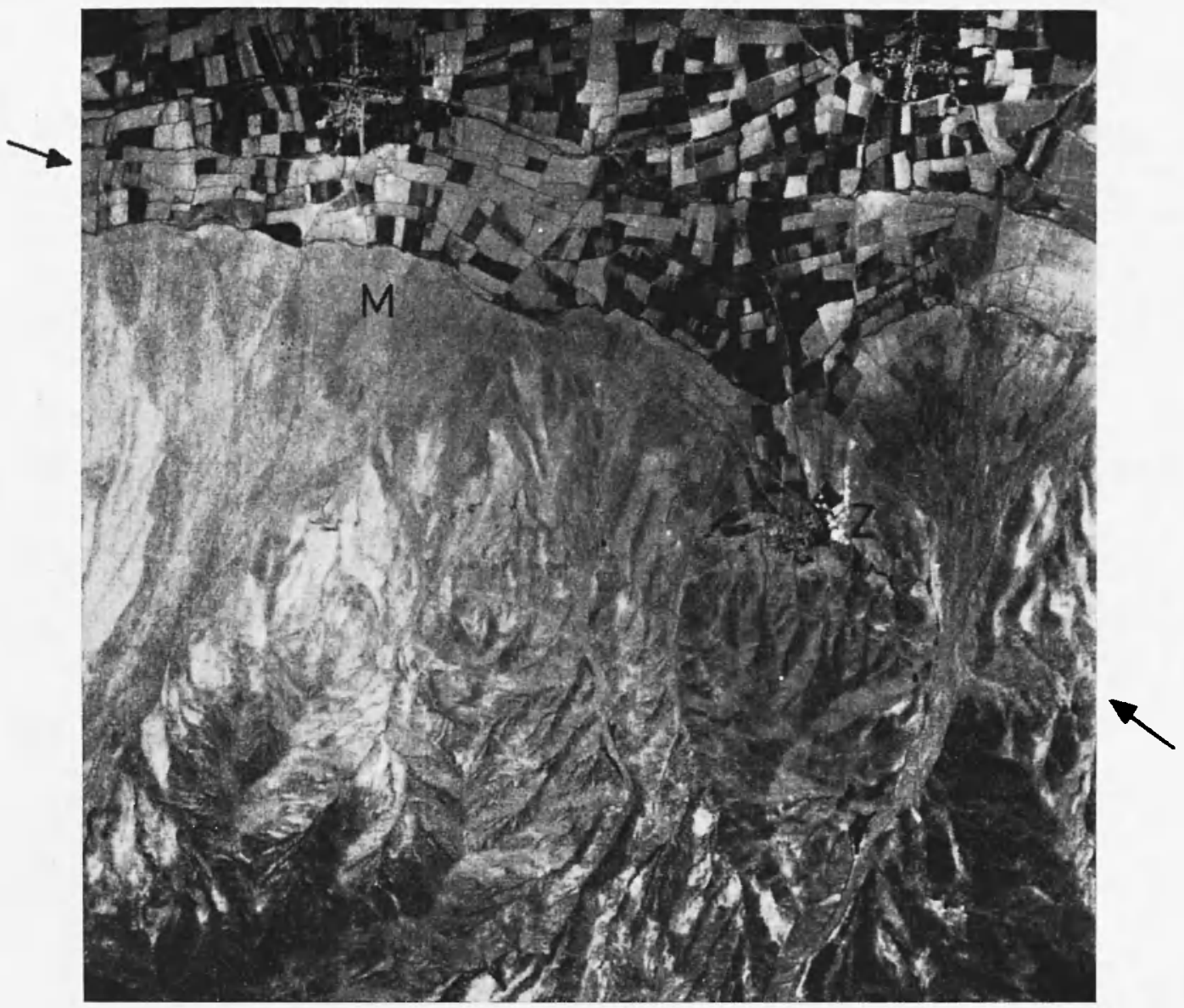

Fig. 26 - Salmas Fatlt, Zavienjuk segment

Aerial view of the fault trace (between arrows) passing through Zaviehjuk (Z) and the Malham cemetery (MI). There are several topographical steps north of, and parallel to, the fault scarp, the most obvious one marking for a short distance the limit between mountain fans and cultivated fields northwest of Zaviehjuk. North is top of photo; area coveed is approximately $4 \times 4 \mathrm{~km}$.

cemetery, the fault enters cultivated fields with an apparent throw of about $6 \mathrm{~m}$ partly rue to a pre-existing topographical step (Fig. 32). It gradually bends back to a $N 125^{\circ}$ direction near the Zola Clay liver. 


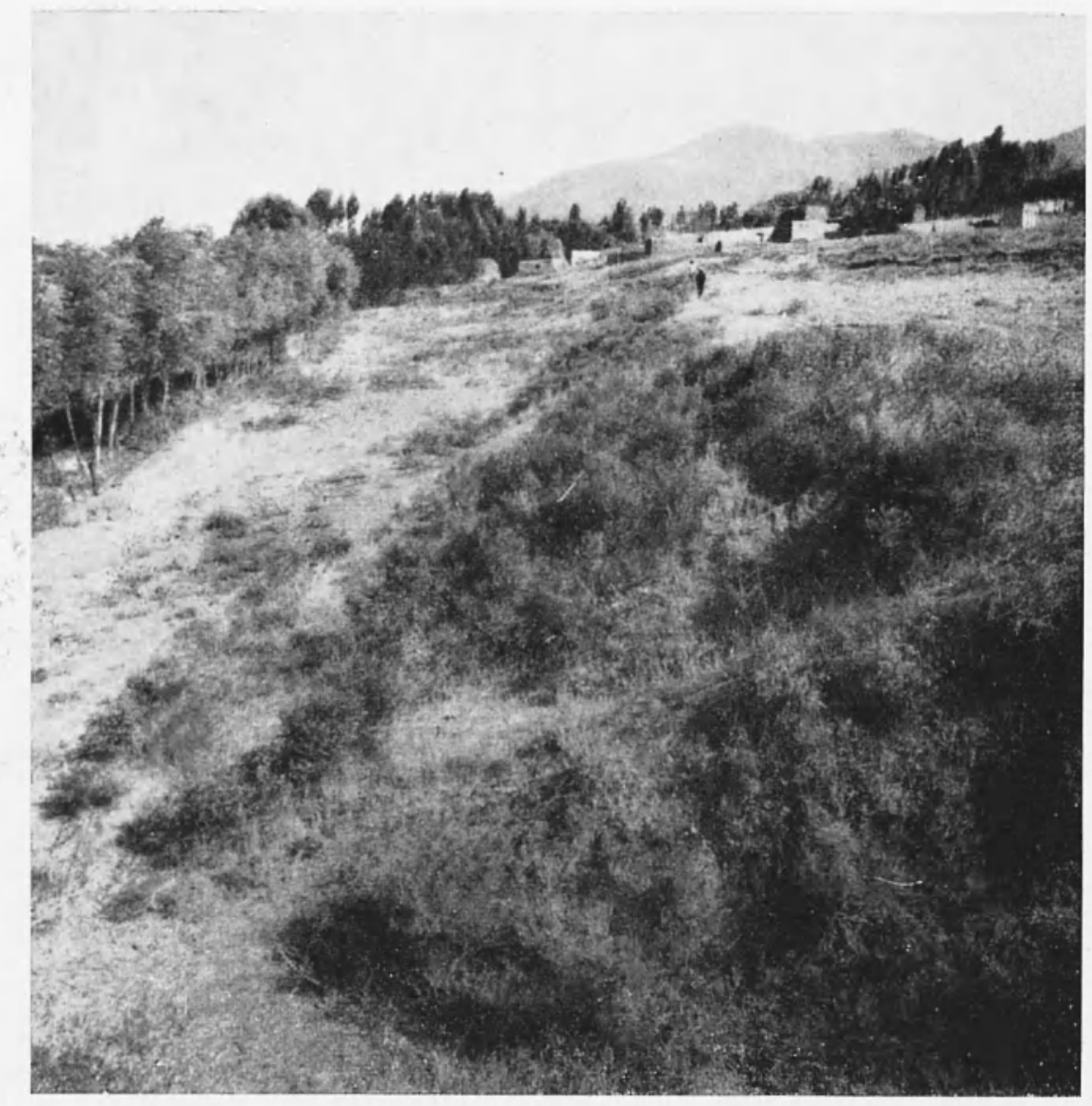

Fig. 27 - Salmas JaUt.t at ZavieiluUk

The two persons are walking along the croded fault searp which crosses the Zaviehjuk village in the backeround. The vertieal throw is here about $3 \mathrm{~m}$ ( $\mathrm{XE}$, i.e. loft side, down). Looking SE.

West of the Zola (hay, and up to the Dowshivan Su at Zarindarreh, the fault crosses a much flatter topograply in a region subject to spring floods. The scarp is here rarely visible, but the fault trace is marked by a wirle linear depression across the fields along which the cultivations are interrupted. Some witnesses mentioned that the fault continued along the valley in the direction of Nazirabad, but field evirlence is lacking on this point. However, in the Dar Darreh valley, east of the pre-earthquake location of Sowfiabal, deep open 


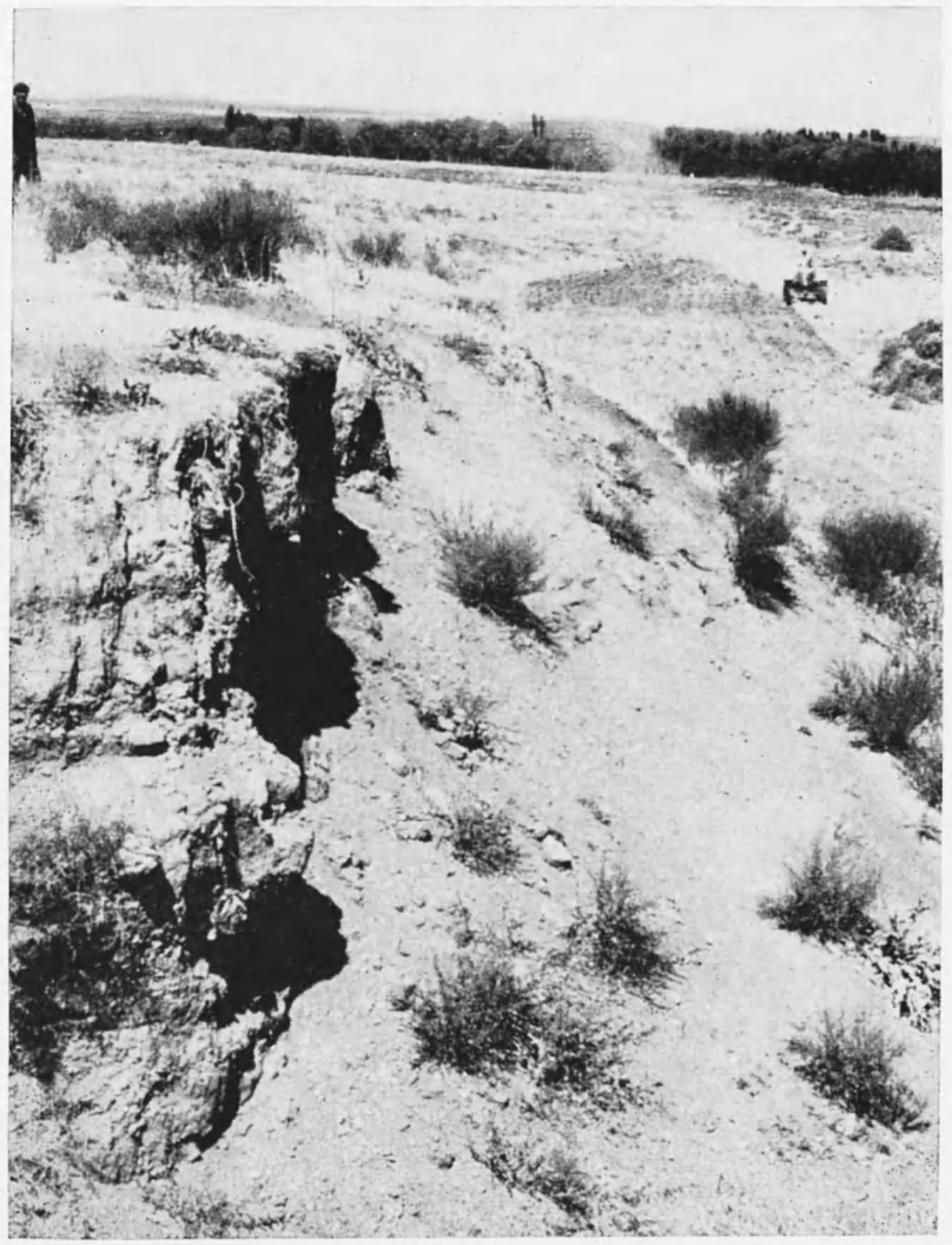

Fig. 28 - Salmas FaUl, ZavieiJuk sagmeit

$5 \mathrm{~m}$ vertical throw west of Zaviehjuk. Note the undisturbed gravel bed. ding. Looking SE.

cracks were observed in a travertine plateau, somewhat similar in appearance but less systematic in pattern to those described east of 


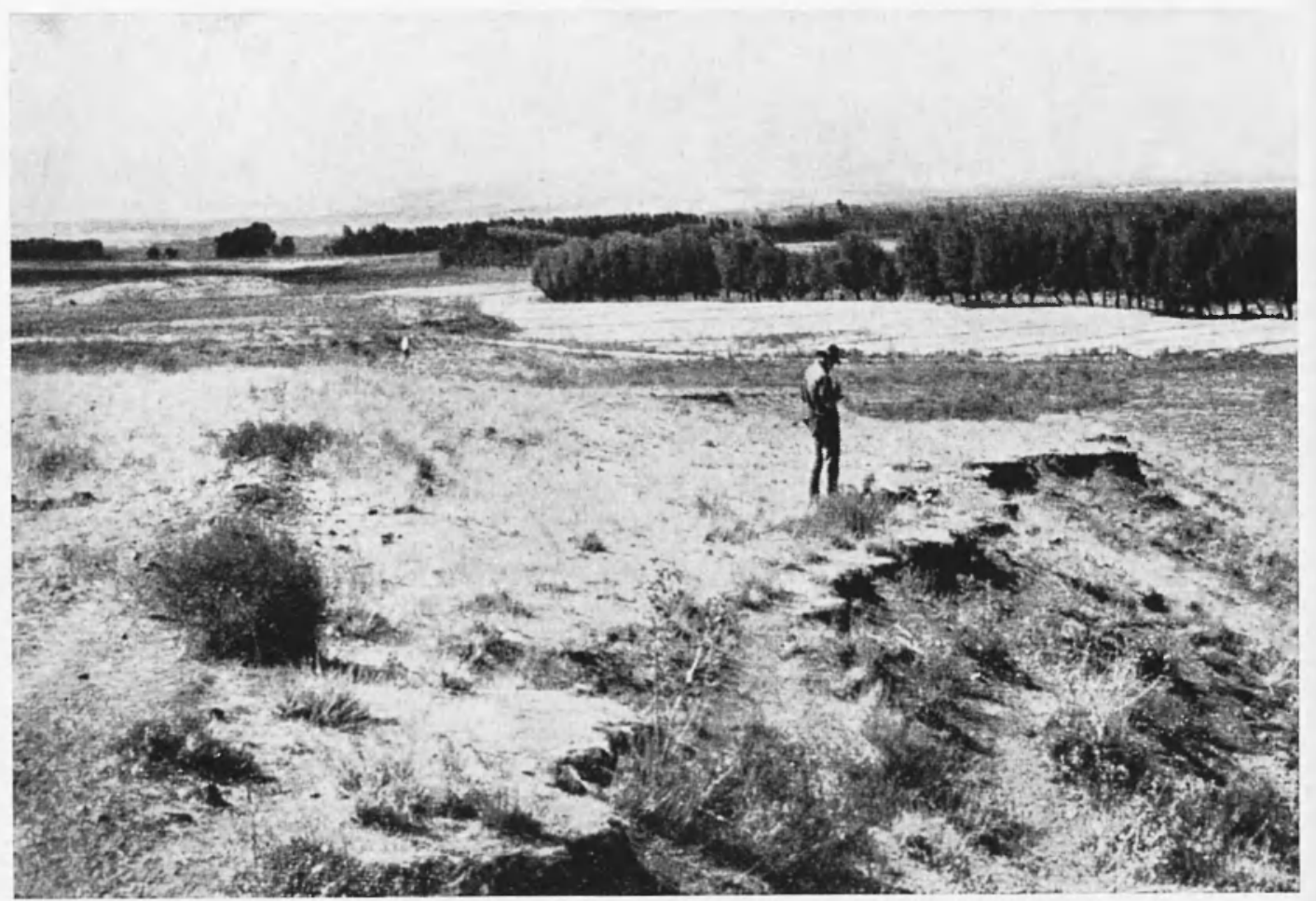

Fig. 29 - Salmas fault, Zavieijuk segment

The persons in the foreground and middle background are standing on 2 seperate en echelon scarps indicating right-lateral wrench movement. The line of trees marks a topographical step probably due to a previous lowering of the Salmas Plain. Looking $\mathrm{N}$.

Akhian (p. 190). The origin of these fractures is not clear, and tension cracks due to incipient landslides cannot be altogether discarded.

Immerliately north of the Zaviehjuk segment, between Zaviehjuk and the Zola Chay, several topographic steps can be observed running approximately parallel to the fault trace. Three such steps can for example be seen between the scarp and Malham (Fig. 26). One of these steps constitutes the present-day boundary between the irrigaated fields and the mountain fans. These steps are a few meters high and very similar in appearance to the degraded earthquake fault scarp. Their most likely interpretation is that they represent previous 


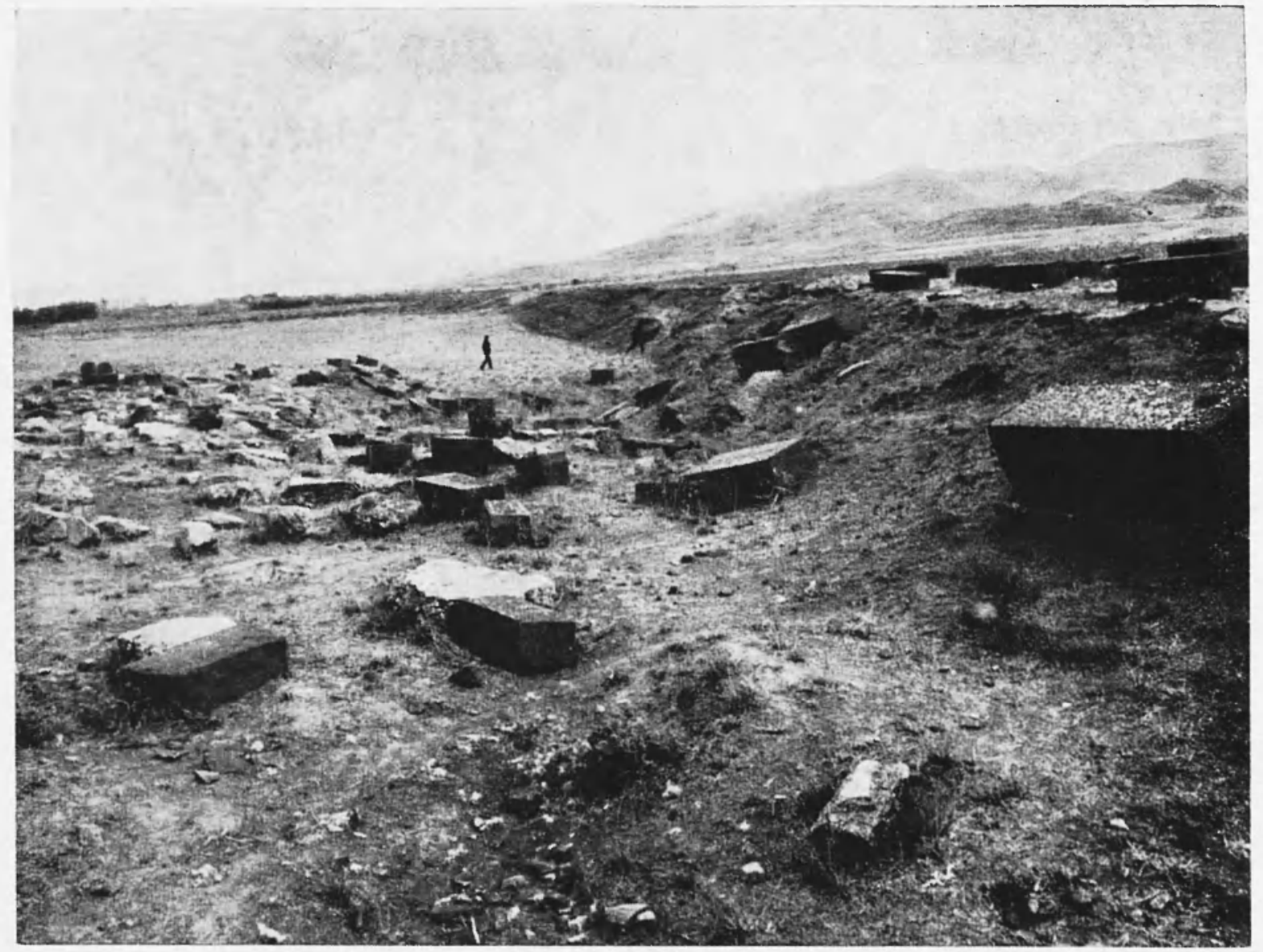

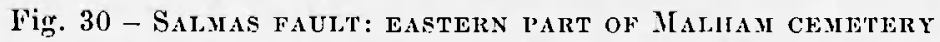

The line of tombstones delineating the far edge of the cemetery shows the narrow graben located at the foot of the searp. Searp runs from right-hand side of photo to background. Apparent throw is about $4 \mathrm{~m}$. 


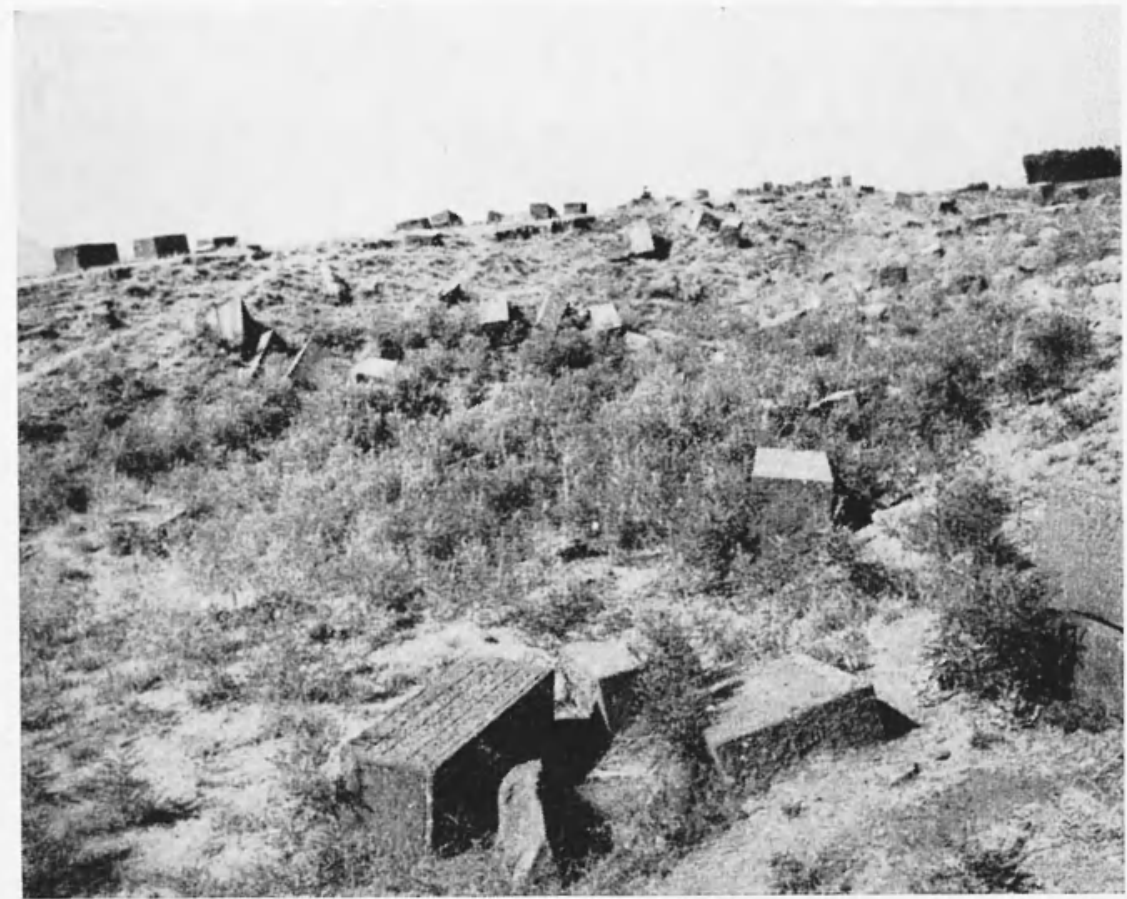

Fig. 31 - Salmas Fault: western part of Malina cemetery

Eyewitnesses elaim that the fault searp was originally nearly vertical. Apparent throw and estimated right-lateral movement are each of the order of $4 \mathrm{~m}$. Looking $\mathrm{TV}$.

stages of subsidence of the Salmas Plain with respect to the mountains in the south.

The Darmanava thermal spring near Issy $\mathrm{Su}$ is located in the exact southeastern continuation of the Akhian segment, about $11 \mathrm{~km}$ beyond the point where the earthquake fault stopped. It is a sulphurous spring at a temperature of $37.5^{\circ} \mathrm{C}$ used for medical purposes, and depositing a whitish carbonate of soda. Its flow decreased appreciably after the earthquake. About $10 \mathrm{~km}$ north of the fault, at the northern foot of the isolated hill marked 1628 in Fig. 3, a cold $\left(18^{\circ} \mathrm{C}\right)$ gazeous spring appeared during the earthquake and was subsequently named Zelzele Bolaghi. It is reported to have taken a muddy colour after a small shock felt in Shahpur on the 22 June 1973. Apparently there was also a hot medicinal spring near Sadaghian, but this was not visited by the authors. 


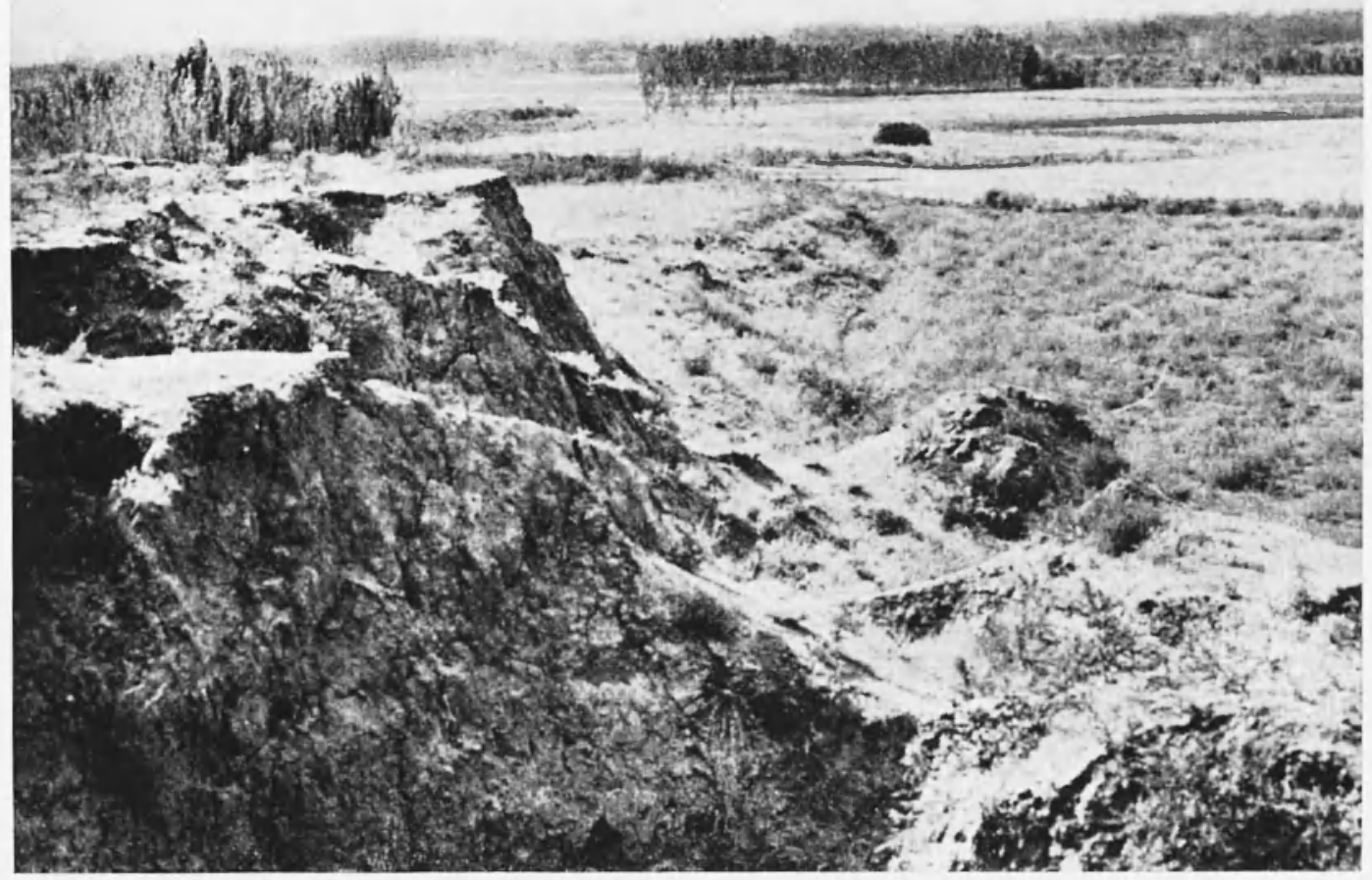

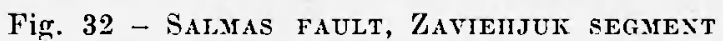

The earthquake fault scarp is here surimposed on a pre-existing topographical step, with a resulting apparent throw of about $6 \mathrm{~m}$. Between Malham and the Zola Chay, looking NW.

\section{Derik Fault.}

The Derik Fault, which, like the Salmas Fault, was associated with the main shock, can be followed to-rlay from a point just enst of the Dowshivan Su to the left bank of the Rud Aqbarzeh, and beyond this point, with an offset, along the right bank of the Rud $A$ qbarzeh (Fig. 33). Along its main section between the two rivers it marks the limit between a crushed amphibolite in the north and a crushed diorite in the south, with occasional pegmatite outcrops along the shear zone. The dip of the geological fault is $N 75^{\circ}-80^{\circ}$, and the vertical earthquake displacement was about $1 \mathrm{~m}$ (NW down) (Fig. 34). Suitable markers could not be found to measure horizontal displace- 


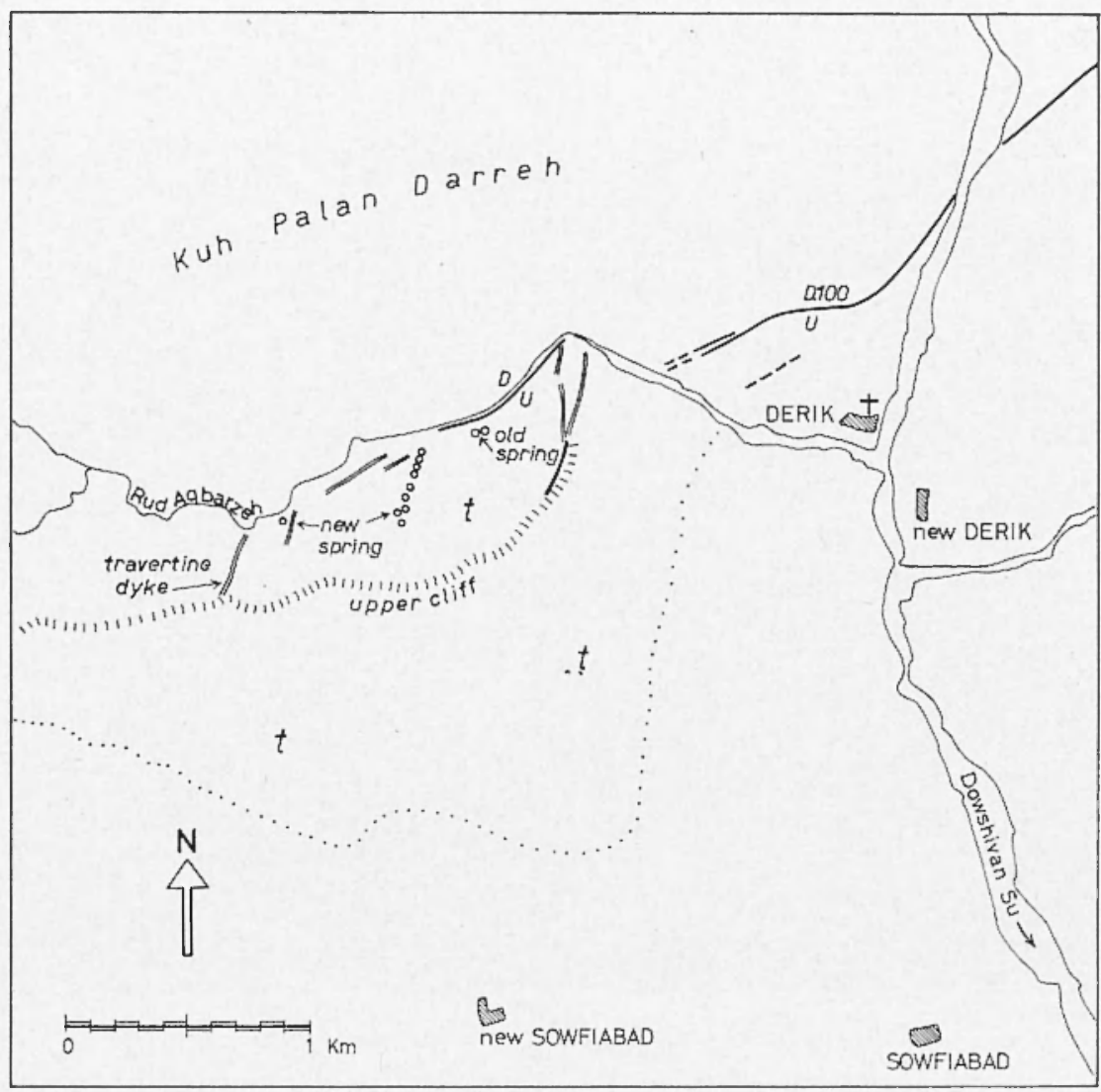

Fig. 33 - Derik FautT

Trace of earthquake fault from field mapping and 1:20,000 aerial photography. Number indicates vertical displacement in centimeters, $U$ up, $D$ down. Dotted line is approximate southern limit of travertine outerop $(t)$, northern limit being formed by the Rud Aqbarzeh.

ments. The overall trace of this section strikes approximately $\mathrm{N} 45^{\circ}$, but includes also a central E-W kink. At its southwestern end, this section stops quite suddenly before reaching the Rud Aqbarzeh and no fractures could be found in the same alignment on the opposite (right) bank. However, about $300 \mathrm{~m}$ further upstream on the rightbank, long cracks were formed parallel to the river in the travertine deposits (Fig. 35). Their overall direction is about $\mathrm{N} 45^{\circ}$. They mark the edge of a cliff along which travertine was deposited from two 


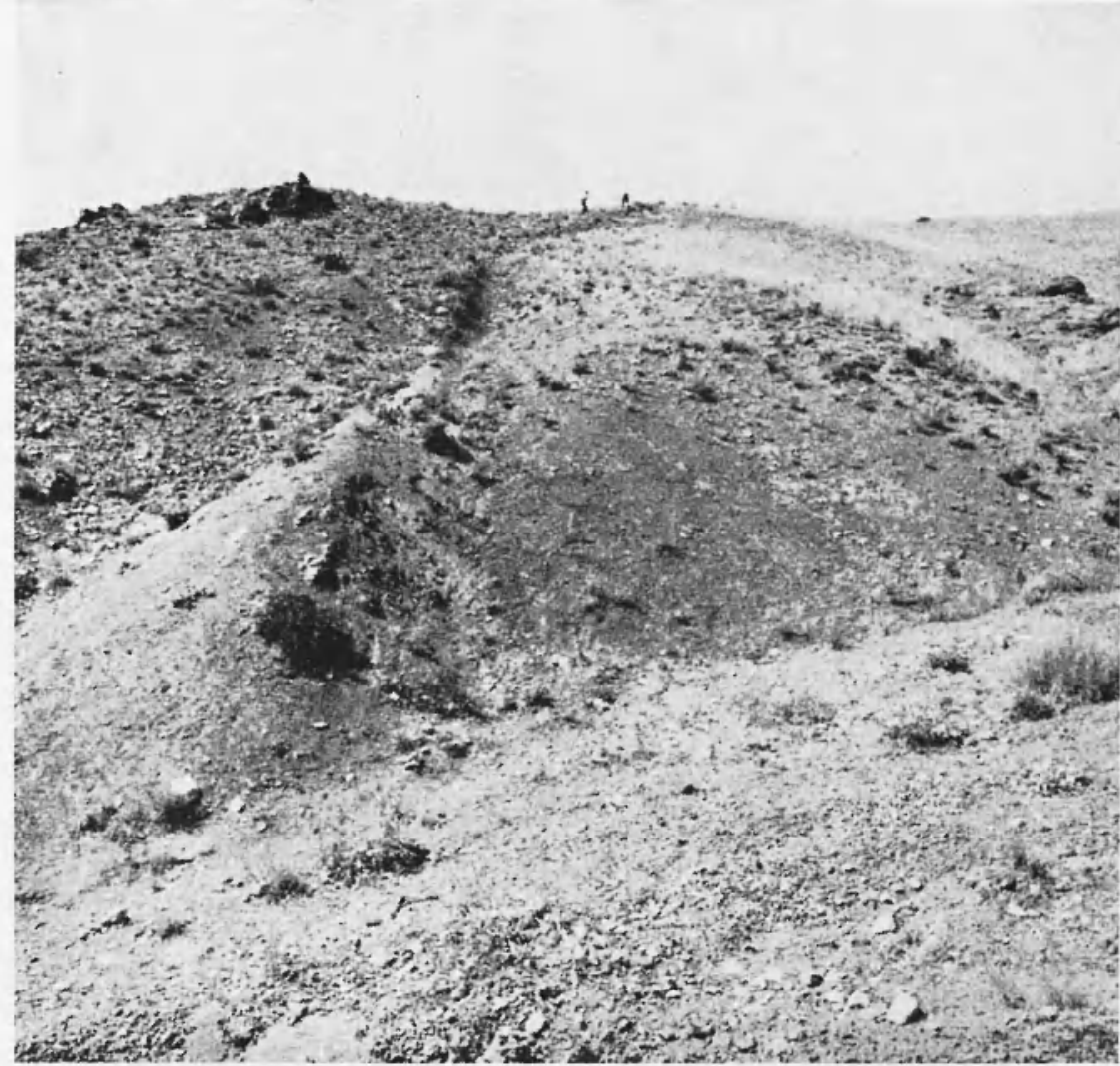

Fig. 34 - DERIK FAULT

Section north of the old village. Vertical displacement is about ] $\mathrm{m}$ ( $\mathrm{NW}$, i.e. right side, down). Jooking SW.

springs up to the time of the earthquake in 1930. At the earthquake, these springs ceased, and new springs appenred and are still active to-day, in two locations, respectively $200 \mathrm{~m}$ and $800 \mathrm{~m}$ further upstream. At the first location, 8 small springs are aligned along about $300 \mathrm{~m}$ in a $\mathrm{N} 1 \mathrm{~J}^{\circ}$ direction, and at the second location a larger spring (about $2 \mathrm{l} / \mathrm{s}$ ) has already deposited since 1930 an appreciable amount of travertin (Fig. 36). The temperature of the water $\left(33^{\circ} \mathrm{C}\right)$ is about $2.5^{\circ} \mathrm{C}$ lower than that of the pre-earthquake springs $\left.{ }^{(12}\right)$. The entire region of the right-bank of the Rud Aqbarzeh is covered by a massive outcrop of an older travertine in sub-horizontal deposits. A few 


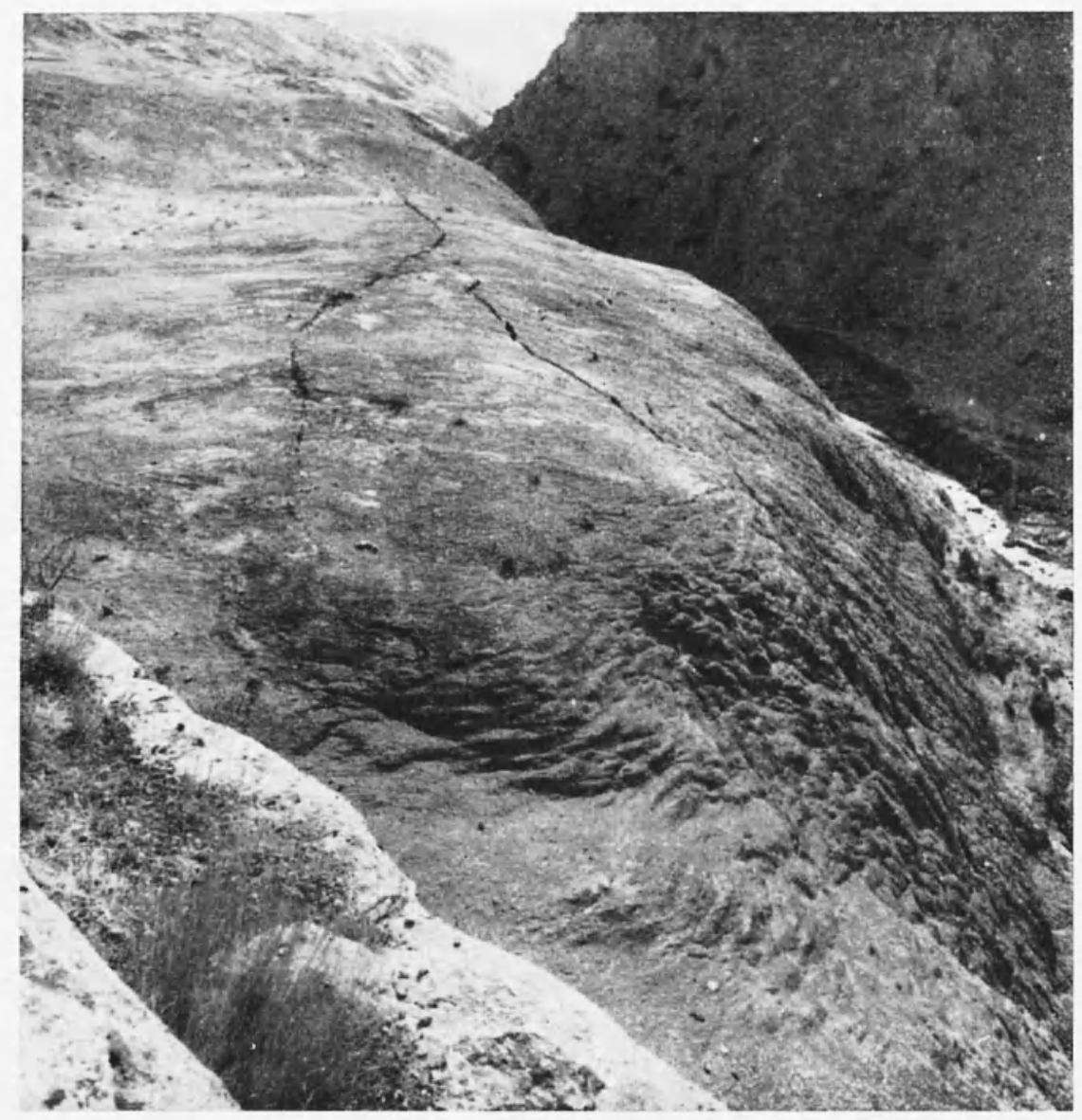

Fig. 35 - DeriK Fault

Earthquake fractures in travertine on the right-bank of the Rud Aqbarzeh. The main fractures are linear and over several hundred meters in length. Looking SW.

thin dykes of the same travertine cut vertically through these deposits and stand out in the topography. They are oriented in two directions: $\mathrm{N} 15^{\circ}$ and located in the approximate continuation of the earthquake cracks, and N5 i.e. approximately parallel to the new spring alignment (Fig. 33).

If the entire structure formed by the earthquake fault between the two rivers and the travertine structures on the right-bank of the 


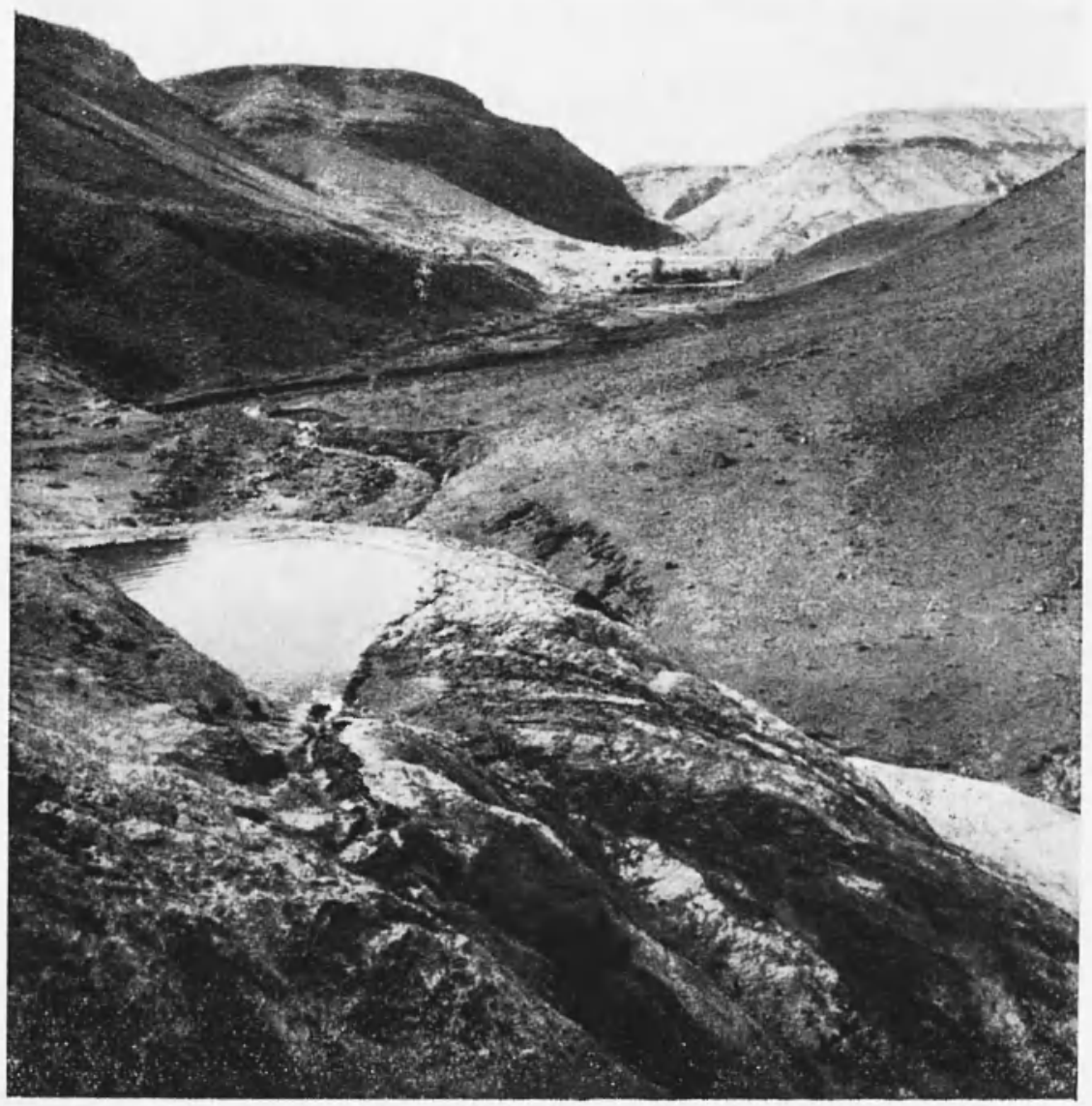

Fig. 36 - Derik therMal SPRING

The main spring which appeared with the earthquake in 1930 las already deposited an appreciable amount of new travertine. Layering in the background cliffs is formed by consecutive Quaternary basalt flows. Looking SW.

Aqbarzeh is considered, the simplest interpretation is that there are 3 en echelon segments in a left-lateral disposition, the first two being formed by the fault north of Derik and on either side of the E-W kink, and the third by the earthquake fractures in the travertine near the pre-1930 springs. In this interpretation the alignment of new springs and travertine dykes would correspond to the direction of the maximum principal stress of the left-lateral deformation. 


\section{Non-tectonid GRound EFFECTS}

Besides the ground deformations of tectonic origin described above, other ground features of secondary origin were also observed (Fig. 3). Many villages in the Salmas Plain reported waterlogging and flooding, often accompanied by ground fissures. These could be either due to the lowering of the Plain and a consequent relative rise of the water table, or to a liquefaction effect caused by shaking. Mountain springs in two villages at the erlge of the Salmas Plain in-

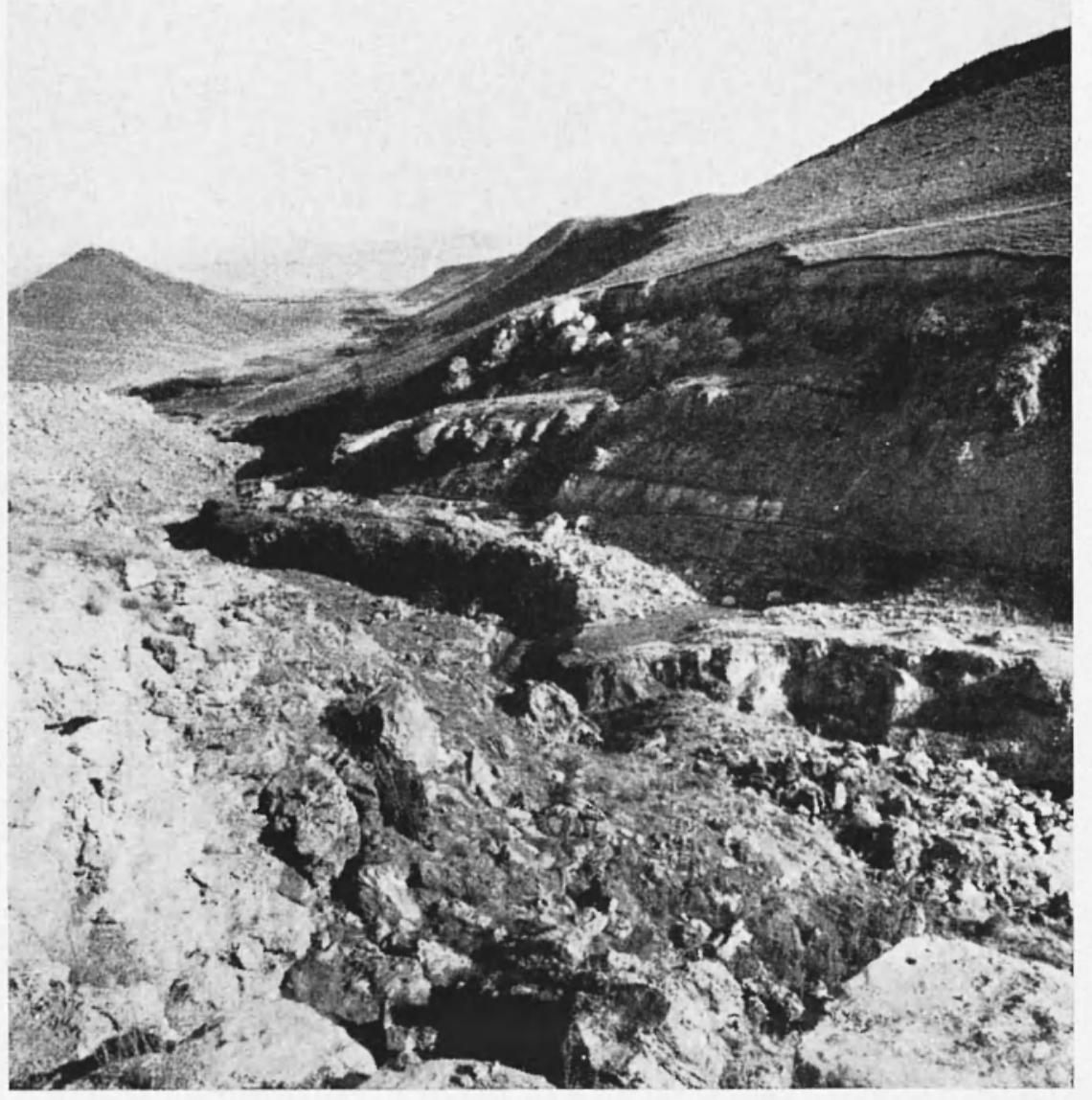

Fig. 37 - FARTHQUaKe TRIGGERED LANDSLIdE

Landslide near Nazirabad. Looking SE along the Dowshivan Su valley in the extension of the Salmas Fault. 


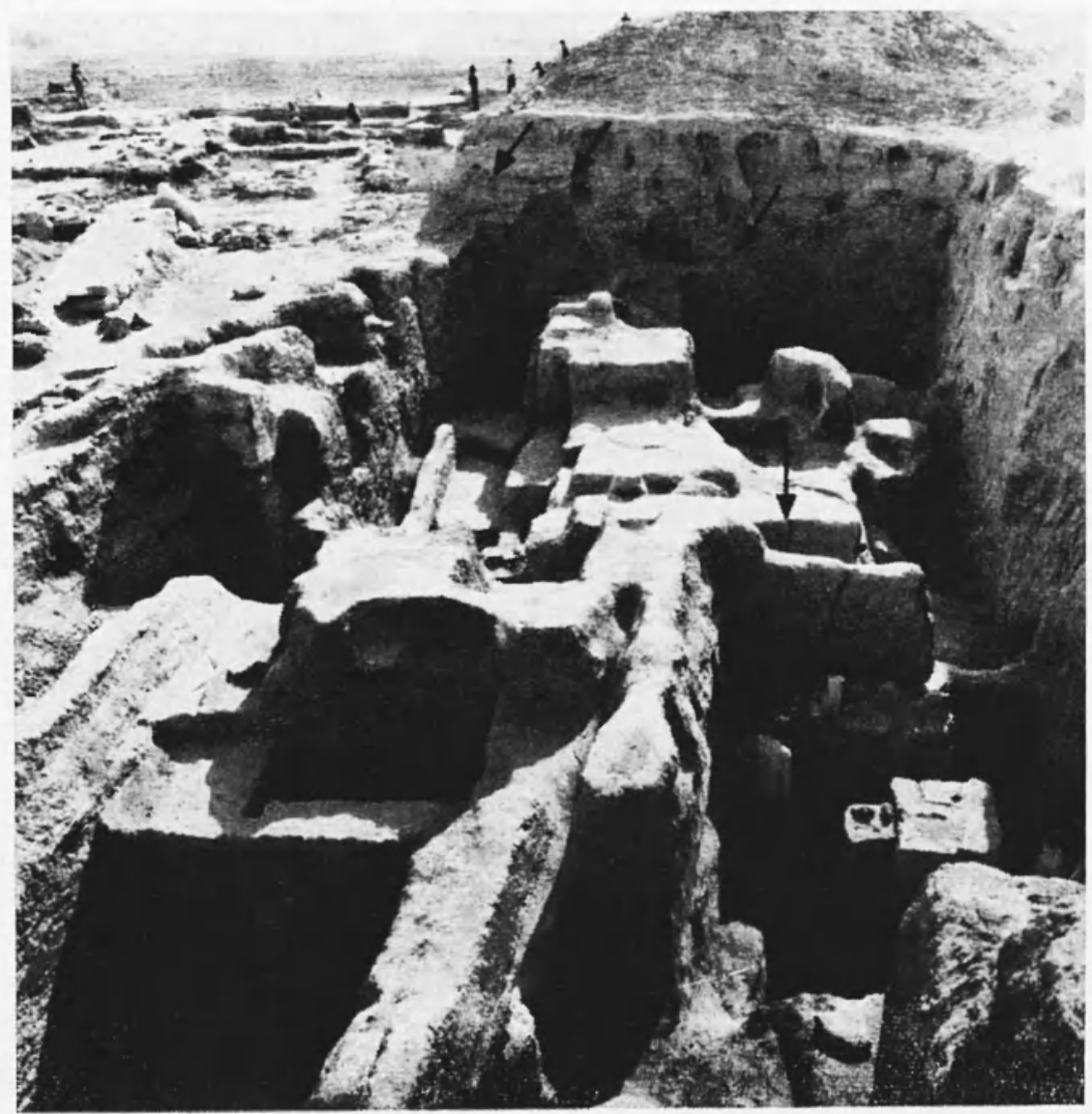

Fig. 38 - Haftavan TEPE

Fractures thought to be of earthquake origin (arrows) revealed by the archeological dig.

creased their flow (Tamar and Zaviehjuk); in some of the higher mountain villages springs decreased, and in two cases ceased altogether (Alibolagh and Hablaran). Several landslides also occurred, the largest in the mountains near Nazirabad (Fig. 37) and at Drishik Tepe, an archeological mound south of the village of Drishik. Recent excavations at Haftavan Tepe also revealed fissures which may be interpreted as incipient landslide cracks $\left(^{4}\right)$ (Fig. 38). Large tension cracks resulted from a bedding-plane slip in Eocene conglomerates 
Table 3 - Aftershocks of tHe salMAS EARTIQUAKE Instrumental and macroseismic data. Newspaper information is given as printed, i.e. in the persian calendar and local time (GMT, $+3 \mathrm{hrs}$ ). Abbrevia-

\begin{tabular}{|c|c|c|c|c|c|c|c|c|c|c|}
\hline$N^{o}$ & & ate & & $\begin{array}{c}\text { GMIT } \\
{ }_{h} \quad s\end{array}$ & $\stackrel{\circ N}{\varphi}$ & $\begin{array}{c}\mathrm{oE} \\
\lambda\end{array}$ & $h$ & $M$ & Ref. & Obs. \\
\hline 165 & 'Tue & $6 \mathrm{M}$ & May & 070326 & 37.98 & 44.88 & 33 & $51 / 4$ & ISSR & 21 \\
\hline 166 & Wed 1 & $11 \mathrm{M}$ & May & 223427 & 38.22 & 44.66 & 33 & 7.3 & ISSR & 116 \\
\hline 167 & Wed & $7 \mathrm{MI}$ & May & 044746 & & & & 4 & ISS & 2 \\
\hline 168 & Wed & $7 \mathrm{MI}$ & May & 045840 & & & & $41 / 4$ & ISS & 4 \\
\hline 169 & Ved & & May & 052424 & & & & 4 & ISS & 2 \\
\hline 170 & Wed & $7 \mathrm{MI}$ & May & 054230 & & & & $41 / 1$ & ISS & 5 \\
\hline 171 & Wed & & May & 092937 & 37.48 & 44.69 & & $41 / 2$ & ISSR & 5 \\
\hline 172 & Wed & $7 \mathrm{MI}$ & May & 105825 & & & & $41 / 4$ & ISS & 3 \\
\hline 173 & Wed & $7 \mathrm{MI}$ & May & 113142 & & & & $41 / 4$ & ISS & 4 \\
\hline 174 & Wed & $7 \mathrm{MI}$ & May & 134748 & & & & $41 / 4$ & ISS & 11 \\
\hline 175 & 'Thu & & May & 052932 & 38.25 & 45.37 & 33 & 5 & ISSR & 7 \\
\hline 176 & Thu & & May & 142352 & 40.09 & 44.39 & 33 & $4 / 2$ & ISSR & 6 \\
\hline 177 & Thu & $8 \mathrm{M}$ & May & 150528 & 38.13 & 35.13 & 33 & 5 & ISSR & 12 \\
\hline 178 & Thu & $8 \mathrm{M}$ & May & 153528 & 38.41 & 45.07 & 33 & $61 / 4$ & ISSR & 79 \\
\hline 179 & Thu & $8 M$ & May & 233822 & 37.56 & 44.73 & 33 & 5 & ISSR & 9 \\
\hline 180 & Fri & $9 \mathrm{NI}$ & May & 014300 & & & & $41 / 2$ & ISS & 6 \\
\hline 181 & Fri & $9 \mathrm{H}$ & May & $08-\longrightarrow$ & & & & 4.4 & $\mathrm{KV}$ & \\
\hline 182 & Sat & $10 \mathrm{~N}$ & May & 214333 & 38.24 & 44.92 & 33 & 5 & ISSR & 16 \\
\hline 183 & Sat 1 & $10 \mathrm{M}$ & May & 235920 & & & & 4 & ISS & 5 \\
\hline
\end{tabular}


tions $\mathrm{KV}=$ Karnik 1969 ; ISS = International Seismological Summary, Edinburgh; ISSR = ISS recalculated; $\mathrm{E}=$ Etela'at newspaper, Tehran; Egh $=$ Egham newspaper, Tehran; $\mathrm{T}=$ Tabriz newspaper, Tabriz.

\section{NEWSPAPER INFORMATION}

\begin{tabular}{|c|c|c|c|c|}
\hline \multicolumn{2}{|c|}{ Date } & Time & Place & Reference \\
\hline $\begin{array}{l}\text { fores } \\
\text { main } \\
\text { Wed }\end{array}$ & $\begin{array}{l}\text { hock } \\
\text { shock } \\
17 \text { Ord }\end{array}$ & after sunrise & Urmiah & T. 20 Ord \\
\hline Thu & 18 Ond & $4 \mathrm{pm}$ & Julfa & T. 21 Ond \\
\hline Thuu & 18 Ord & $5 \mathrm{pm}$ & Ajabshir, Mianduab, Marand & T. 21 Ord \\
\hline Thu & 18 Ord & $6 \mathrm{pm}$ & $\begin{array}{l}\text { Sharajkhaneh, Fhoy, Qutur, } \\
\text { Tabriz Shakar Iazi. }\end{array}$ & $\begin{array}{l}\text { T. } 20 \text { Ord E. } 20 \\
\text { Ord Egh } 20 \text { Ord }\end{array}$ \\
\hline Thu & 18 Ond & night & Salmas & T. $200 \mathrm{rd}$ \\
\hline Fri & 19 Ord & $11 \mathrm{am}$ & Gavkan & T. 21 Ord \\
\hline Fri & 19 Ord & $5 \mathrm{pm}$ & Solduz & T. 21 Ord \\
\hline Fri & 19 Ord & $6: 15 \mathrm{pm}$ & Maragheh & T. 21 Ord \\
\hline Fri & 19 Ord & $6: 30 \mathrm{pm}$ & $\left.\begin{array}{l}\text { Gavkan, } \\
\text { Ahar, } \\
\text { Maragheh }\end{array}\right\} \begin{array}{l}\text { Same } \\
\text { as } 178 ?\end{array}$ & T. 21 Ord \\
\hline Fri & 19 Ord & no time & Sayen Qaleh & T. 22 Ord \\
\hline Fri & 19 Ord & evening & Tabriz & T. 21 Ord \\
\hline Sat & 20 Ord & early morning & Tabriz & T. 21 Ond \\
\hline Sat & 20 Ord & afternoon & Salmas & T. 22 Ond \\
\hline Sat & 20 Ord & afternoon & Mianduab & Egh 21 Ond \\
\hline Sun & 21 Ord & $1 \mathrm{am}$ & Salmas & T. 23 Old \\
\hline Sun & $21 \mathrm{Ord}$ & $3: 30 \mathrm{am} ?$ & Gavkan & T. 23 Ord \\
\hline Sun & 21 Ord & no time & Sharafkhaneh & T. $230 \mathrm{rd}$ \\
\hline Sun & 21 Ord & ? & Mahaleh Dezmar & T. 23 Ord \\
\hline Sun & 21 Ord & no time & $?$ & E. 22 Ond \\
\hline Sun & 21 Ord & up to $5 \mathrm{pm}$ & Salmas (4 shocks) & T. 24 Ord \\
\hline
\end{tabular}




\begin{tabular}{|c|c|c|c|c|c|c|c|c|c|}
\hline No & & Date & ${ }_{h}^{\text {GMIT }}$ & $\begin{array}{r}{ }^{\circ N} \\
p\end{array}$ & $\stackrel{0}{\mathrm{E}}$ & $h$ & $M$ & Ref. & Obs. \\
\hline 187 & Werl & 14 May & $0259--$ & & & & 4.3 & $\mathrm{KV}$ & \\
\hline 188 & Wed & 21 May & 135051 & & & & $4^{1 / 2}$ & ISS & 7 \\
\hline 189 & Fri & 23 May & 094823 & 38.09 & 45.15 & 33 & $51 / 4$ & ISS R & 20 \\
\hline 190 & Thu & 29 May & 171459 & 38.06 & 44.71 & 33 & $51 / 2$ & ISSR & 27 \\
\hline 191 & Wod & $4 \mathrm{Jun}$ & 072808 & 38.17 & 45.13 & 33 & $51 / 4$ & ISSR & 42 \\
\hline 193 & Wed & $9 \mathrm{Jul}$ & 043557 & 37.73 & 44.55 & 33 & $4 \frac{1}{2}$ & ISSR & 7 \\
\hline 194 & Sun & 3 Aur & 220559 & 38.43 & 44.64 & 33 & $51 / 4$ & ISSR & 20 \\
\hline 196 & Thu & $21 \quad A u g r$ & 065529 & 38.40 & 45.02 & 33 & $41 / 2$ & ISSR & 4 \\
\hline
\end{tabular}


NEWSPAPER INFORMATION

\begin{tabular}{|c|c|c|c|c|c|}
\hline \multicolumn{3}{|c|}{ Date } & Local & Place & Reference \\
\hline Sun & 21 & Ord & night & Salmas (4 shocks) & T. 24 Ord \\
\hline Mon & 22 & Ord & no time & Salmas & E. 22 Ord \\
\hline Thu & 25 & Ord & no time & Salmas & T. $310 \mathrm{Ord}$ \\
\hline Fri & 26 & Ord & no time & Salmas (3 shocks) & E. 31 Orr \\
\hline Mon & 29 & Ord & $10: 15 \mathrm{am}$ & Salmas & $\begin{array}{l}\text { E. 31 Ord } \\
\text { Egh } 31 \text { Ond }\end{array}$ \\
\hline Mon & 29 & Ord & no time & Shabestar & T. 3 Kho \\
\hline Mon & 29 & Ord & night & Salmas (3 shocks) & E. $310 \mathrm{ord}$ \\
\hline Tue & 30 & Ord & carly morn & Salmas & Egh 31 Ord \\
\hline Tue & 30 & Ord & $2 \mathrm{l} \mathrm{h}$ & Salmas & Egh 31 Ord \\
\hline Thu & 1 & Kho & $7 \mathrm{pm}$ & Tabriz & T. 3 Kho \\
\hline Fri & 2 & Kho & $12: 50 \mathrm{pnn}$ & Tabriz, Salmas & T. 3 Kho \\
\hline Mon & 5 & Khio & $7: 15 \mathrm{am}$ & Salmas & E. 6 Kho \\
\hline Thu & 8 & Kho & 20 or $22 \mathrm{~h}$ & Salmas & E. $10 \& 12$ Kho \\
\hline Sat & 10 & Kho & no time & Salmas (4 shocks) & E. 12 Kho \\
\hline Sun & 11 & Kho & morning & Salmas & E. 12 Kho \\
\hline Mon & 12 & Kho & afternom & Salmas (2 shocks) & E. 13 Kho \\
\hline Wed & 14 & Kho & $10: 30 \mathrm{am}$ & $\begin{array}{l}\text { Tabriz, Salmas, Kloy, Ma- } \\
\text { rand, Julfa, Rezayeh, Sha- } \\
\text { rafkhanel, Maragheh, Bo- } \\
\text { nab, Ajabshir }\end{array}$ & T. 15 Kho \\
\hline Wed & 14 & Kho & $4 \mathrm{pm}$ & Tabriz & T. 15 Kho \\
\hline Thu & 15 & Kho & $16: 00 \mathrm{~h}$ & Salmas & E. 21 Kho \\
\hline Fri & 16 & Kho & midnight & Salmas (2 shocks) & E. 2 I Kho \\
\hline Sat & 17 & Kho & morning & Salmas & E. 21 Kho \\
\hline Mon & 19 & Kho & $02: 30$ & Salmas & E. 21 Kho \\
\hline Tue & 20 & Kho & no time & Salmas (2 shocks) & E. 25 Kho \\
\hline Sat & 24 & Kho & $10: 30$ & Salmas & E. 25 Kho \\
\hline Fri & 20 & Tir & $08: 00$ & Khoy & E. 21 Tir \\
\hline Sat & 21 & Tir & $07: 00$ & Salmas & E. 21 Tir \\
\hline Mon & 23 & Tir & $15: 30$ & Khoy (4 shocks) & E. 24 Tir \\
\hline Wed & 25 & Tir & $2 \mathrm{am}$ & Khoy & E. $25 \mathrm{Tir}$ \\
\hline Mon & 30 & Tir & afternoon & Salmas (2 shocks) & E. 31 Tir \\
\hline 'Thu & 2 & Mor & no time & Salmas & E. 6 Mor \\
\hline Sat & 4 & Mor & $14: 00$ & Salmas & E. 6 Mor \\
\hline Sun & 5 & Mor & $02: 30$ & Sayen Qal'eh & E. 5 Mor \\
\hline Fri & 10 & Mor & no time & Salmas & E. 11 Mor \\
\hline Sat & 11 & Mor & morning & Salmas, Khoy & E. 11 Mor \\
\hline Sun & 12 & Mor & $08: 00$ & Khoy & E. 15 Mor \\
\hline Wed & 15 & Mor & evening & Salmas & E. 16 Mor \\
\hline Thu & 16 & Mor & no time & Salnas & E. 16 Mor \\
\hline
\end{tabular}


above Aslanik (Fig. 39). Finally, a very large number of rockfalls took place, especially in the Quaternary basalt ontcrops along the banks of the Zola Chay and the lower Dowshivan Su.

\section{AFTERsilocks}

A large number of aftershocks, known both from instrumental recordings and macroseismic data, followerl the main shock and are

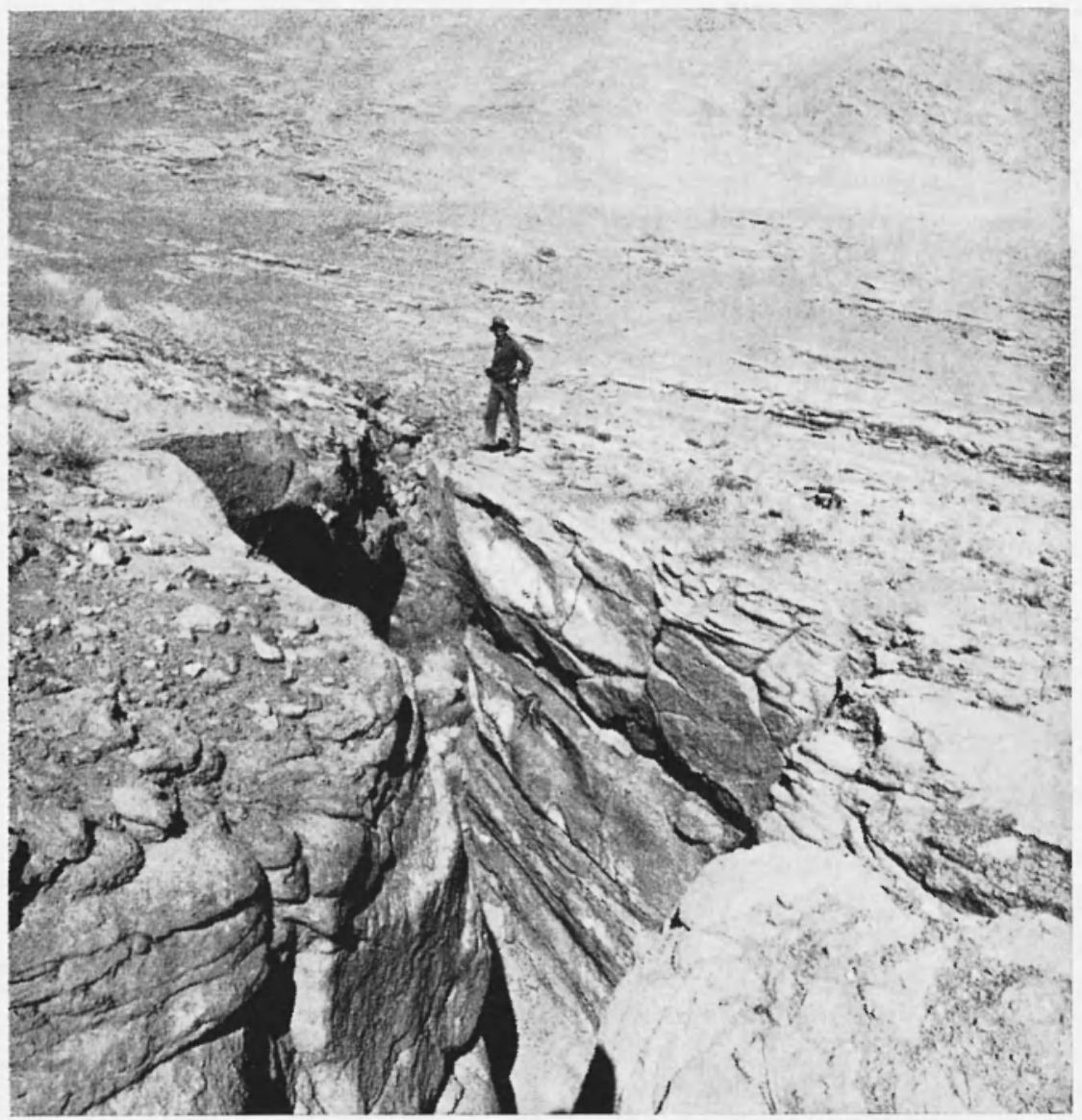

Fig. 39 - Eartiquake triggered BEdDING-PLANe SLiP

Large tension crack resulting from bedding-plane slip in layered Eocene conglomerate west of Aslanik. 
listed in Table 3. However, the epicentres of only the larger shocks were calculated with sufficient accuracy to give an approximate idea of their geographical location; these epicentres, plotted in Fig. 1, seem to delineate a wide N-S zone contained between Lake Rezayeh and the Turkish frontier, and extending from Rezayeh in the south to Khoy in the north.

The largest aftershock ( $M_{b}$ over 6 ) occurred about 40 hours after the main event, on 8 May 1930 at 15 h35m28s GHT. Its instrumental epicentre was located south of Khoy in the Tolehi Dagh mountains bordering the northern edge of the Salmas Plain. It caused slight damage in Sharafkhaneh, Khoy and Qutur. In the Salmas Plain, Shekar Yazi was half-destroyed and 4 (?) people were killed. In this village, the foreshock had been felt only very lightly, and the main shock caused no damage. The aftershock was also strongly felt, but without damage, in the near-by village of Kanyan. In Khosrova, the shock was also strongly felt (p. 166), but no further damage seems to have resulted.

\section{Conclusions}

The documentation collected during this field investigation, supplemented by existing written contemporary accounts, provides a relatively complete picture of the Salmas earthquake, its foreshock and principal aftershock. The main facts are summarizer below.

A foreshock, of estimated magnitude 5.4, occurred on 6 May 1930 at $07 h 03 m 26$ s GMT, preceding the main shock by about $15 \frac{1}{2}$ hours. Its macroseismic epicentre was determined at $38.15 \mathrm{~N} 44.75 \mathrm{E}$, and the region of damage was found to have a diameter of about $15 \mathrm{~km}$. About 25 people were killed, and Dilman and 7 other villages were damaged. Less than $20 \mathrm{~km}$ from the epicentre, the shock was felt so lightly that the inhabitants did not consider it necessary to spend the night out of doors.

The main shock occurred in the night of 6 May 1930 at $22 \mathrm{~h} 34 \mathrm{~m} 27 \mathrm{~s}$ GIIT and was assigned a magnitude of between 7.2 and 7.4 . The macroseismic epicentre was determined at approximately $38.15 \mathrm{~N} 44.70 \mathrm{E}$, i.e. nearly identical to the epicentre of the foreshock. It was felt in Tabriz and in many of the larger towns of Azerbaijan, and perceptible as far as Nakhichevan and Tiflis in the USSR. In the epicentral region it destroyed Dilman and about 60 villages located in the Salmas Plain 
and in the bordering mountains, in a region measuring approximately $40 \mathrm{~km} \mathrm{E-W} \mathrm{and} 20 \mathrm{~km}$ N-S. About 40 churches, mostly located in the Salmas Plain were also destroyed or damaged, and tombstones in 3 cemeteries were displaced, usually to the north. The total number of people killed was about 2514 , casualties occurring mainly amongst the part of the population which had not felt, or not heeded, the foreshock. An isolated pocket of destruction was located at Mamaqan, about $25 \mathrm{~km}$ south of the macroseismic epicentre.

Faulting occurred during the main shock in two localities: at the southern edge of the Salmas Plain, in a NW-SE direction, with a right lateral displacement of up to $4 \mathrm{~m}$ and a vertical displacement of over $5 \mathrm{~m}$ (NE down); and in the northwest near Derik, in a NE-SW direction, left-lateral, with the $\mathrm{NW}$ side down by about $1 \mathrm{~m}$. Changes in thermal springs were associated with both faults. The combined result of movement on the two faults is a lowering and a displacement to the east, of the Salmas Plain. Many secondary ground deformations were also observed.

Aftershocks were most numerous in a broad $\mathrm{N}-\mathrm{S}$ zone between Lake Rezayeh and the Turkish frontier. The strongest aftershock occurred about 40 hours after the main event, on 8 May 1930 at $15 \mathrm{~h} 35 \mathrm{~m} 28 \mathrm{~s}$ GIIT, and was centered in the mountains bordering the Salmas Plain in the northeast. Here one village, Shekar Yazi, undamaged by both foreshock and main shock, was partly destroyed.

The fact that a relatively complete picture could be assembled of an earthquake which happened 43 years ago, and about which practically nothing was known so far, was partly due to exceptional circumstances: existence of a minority Christian population which remembered the event, presence of larger buildings (the churches) still visible to-day, accurate eyewitness account, etc. It confirms however an observation already made for less well documented early 20th century earthquakes in Iran, i.e. accurate information concerning these events is still available to-day in the field $\left(^{20}\right)$. To study these earthquakes is of special importance in cases such as Salmas for which instrumental determinations may be inaccurate and written macroseismic data virtually non-existent.

\section{ACKNowledgements}

The field investigation, undertaken as a Geological Survey of Iran - Imperial College joint project, the latter being supported by 
a N.E.R.C. grant, was greatly helped by the hospitality of the inhabitants and local authorities of the region, and in particular by the guidance of several individual survivors of the catastrophe. Amongst these were Father Mesrob Minassian, Haji Ali Kassabi and Ali Behnia in Shahpur, Megerdich Galostian in Payajuk, Hike Sarvarian in Malliam, Hagop Megerdichian in Savran, Yuseb and Ashor Khashilo in Khosrova, Joseph Paul Heydari and Gevergis Yusep Khosrowabadi in Patehvir and Herand Melikian in Haftavan. Many others, not mentioned here, also provided us with invaluable information in the field. We are greatly indebted to Rev. D. V. Panossian, Patriarch Vicar-General of the Armenian Diocese in Azarbaijan, whose vast knowledge of the history of the region clarified many points, and who helped us in the dating of several churches. D. Boghossian and A. Badalian in Tehran, and A. Missakian, G. Miridjian and A. Kardachian in Paris helped us in the bibliographical research, as did the French Ministry of Foreign Aflairs in Paris and the French Embassy in Tehran. The Lazarist Mission in Paris provided us with its published reports, even though we have not yet been able to consult its correspondence archives.

\section{REFERENCES}

(1) B.C.I.S. - Bureau Central de Seismologie, Strasbourg, France.

() Berberinn, M. and J. S. Tomalenko (in preparation). - Field study and documentation of the 1930 Salmas (Azerbaijan) earthquake. "Geol. Surv. Iran", Rep.

(3) Brunk, R., 1930. - Das Erdbeben in Persien vom 6 Mai 1930. "Peterm. Geogr. Mitt.", Heft 11/12, 289.

(') Burner, C., 1973. - Excavations at Haftavan Tepe 1971: Third preli- . minary report. Iran, 11, 153-172.

(5) Eginda - The Eghdam Newspaper, Tehran (in Persian).

(6) EtelaAt - The Etelaat Newspaper, Tehran (in Persian).

(2) Franssen, P., 1930. - Correspondence of the Missions Lazaristes. Rezayeh.

(8) Gutenberg, B. and C. F. Richter, 1954. - Seismicity of the Earth and Associated Phenomena. 2nd Ed., "Princeton Univ. Press", U.S.A., $768 \mathrm{p}$.

$\left({ }^{\circ}\right)$ Haratcir. - Haratch Newspaper, Paris (in Armenian).

(10) Karnik, V., 1969. - Seismicity of the European Area. Part I, D. Riedel Publ. Co., Dordrecht, Holland. 
(11) KLEIss, W., 1969. - Bericht über zwei Erlindungsfahten in NordwestIran. "Archaol. Mitteil. Aus Iran", Neue Folge, Band 2, Berlin.

(12) Lofrus, W., 1854. - On the geology of portions of the Turko-Persian. frontier and of the districts adjoining. "Q. J. Geol. Soc. Lond.", 11, 247-345.

(13) Mrovenev, S. V., 1953. - Novaya Seismicheshaya Shlala. "Trud. Geof. Inst.", Akad. Nauk SSSR, 21, 148.154.

(14) Minorsix, V., 1931. - Salmas. "The Eneyclopedia of Islam", 4, 117-118.

$\left({ }^{15}\right)$ Massis. - Massis Calendar, Ed. II. Ajemian, Tabriz (in Armenian).

(16) Nabavi, M. S., 1972. - Seismicity of Iran. M. Ph. Thesis, Lond. Univ., 276 p.

(17) Tabriz. - The Tabriz Newspaper, Tabriz (in Persian).

(18) Tateossiax, II., 1930. - Article in Haratch 31 May 1930.

(19) Tcintenko, J. S. and N. N. Ambraseys, 1973. - Earthquake destruction. of adobe villages in. Iran. "Ann. di Geof.", XXV, 2/3, 357-389.

(20) TCinalesko, J. S., Braud, J. and X. Berberian, 1974. - Discovery of 3 earthquale faults in Iran, 248, 661-663. "Nature".

("1) ZaYia, A., 1930a. - Lettre de M. Abel Zayia à M. Berthounesque, 11 Mai 1930. "Ann. Mission Lazariste", 95, 834-837.

(22) ZaYia, A., 1930b. - Les tremblements de terre. "Missions Lazaristes et Filles de la Charité", Bull., se année, June 1930, 215-220. 